\title{
4. BIOSTRATIGRAPHY OF DIVERSE SILICOFLAGELLATE ASSEMBLAGES FROM THE EARLY PALEOCENE TO EARLY MIOCENE OF HOLES 698A, 700B, 702B, AND 703A: SUBANTARCTIC SOUTH ATLANTIC 1
}

\author{
Paul F. Ciesielski²
}

\begin{abstract}
Nearly complete Paleogene sedimentary sequences were recovered by Leg 114 to the subantarctic South Atlantic. Silicoflagellate assemblages from the Paleogene and immediately overlying lower Neogene from Sites 698 (Northeast Georgia Rise), 700 (East Georgia Basin), 702 (Islas Orcadas Rise), and 703 (Meteor Rise) were examined. The described assemblage from Hole 700B represents the most complete yet described from the Paleocene, encompassing planktonic foraminifer Zones P1b (upper part) through P4 and Subchrons C25N to C23N. All lower Eocene sediments are barren as a result of diagenesis, except for a single sample from Hole 698A. Middle Eocene silicoflagellates described from Hole 702B range in age from early middle Eocene (P10) to late Eocene (P15), with correlations to Subchrons $\mathrm{C} 21 \mathrm{~N}$ to $\mathrm{C} 18 \mathrm{~N}$. Hole 703A contains late Eocene through early Miocene assemblages, with paleomagnetic control from Subchrons C16R to C6AAN.

Leg 114 biosiliceous sequences contain exceptionally diverse assemblages of silicoflagellates. Approximately 155 species and separate morphotypes are described from the Paleogene and earliest Neogene. New taxa described from Leg 114 sediments include Bachmannocena vetula $\mathrm{n}$. sp., Corbisema animoparallela $\mathrm{n}$. sp., Corbisema camara $\mathrm{n}$. sp., Corbisema constricta spinosa n. subsp., Corbisema delicata n. sp., Corbisema hastata alta n. subsp., Corbisema praedelicata n. sp., Corbisema scapana n. sp., Corbisema triacantha lepidospinosa n. subsp., Dictyocha deflandrei furtivia $\mathrm{n}$. subsp., Naviculopsis biapiculata nodulifera $\mathrm{n}$. subsp., Naviculopsis cruciata $\mathrm{n}$. sp., Naviculopsis pandalata $\mathrm{n}$. $\mathrm{sp}$., Naviculopsis primativa $\mathrm{n}$. $\mathrm{sp}$., and Naviculopsis trispinosa eminula $\mathrm{n}$. subsp. Taxonomic revisions were made to the following taxa: Corbisema constricta constricta emended, Corbisema disymmetrica crenulata $\mathrm{n}$. comb., Corbisema jerseyensis emended, and Distephanus antarcticus $\mathrm{n}$. comb.

Silicoflagellate assemblages from the Paleogene and earliest Neogene of Holes 698A, 699A, 700B, 702B, and $703 \mathrm{~A}$ are the basis of a silicoflagellate zonation spanning the interval from 63.2 to $22.25 \mathrm{Ma}$. Silicoflagellate zones recognized in this interval include the Corbisema hastata hastata Zone, Corbisema hastata alta Zone, Dictyocha precarentis Zone, Naviculopsis constricta Zone, Naviculopsis foliacea Zone, Bachmannocena vetula Zone, Dictyocha grandis Zone, Naviculopsis pandalata Zone, Naviculopsis constricta-Bachmannocena paulschulzii Zone, Bachmannocena paulschulzii Zone, Naviculopsis trispinosa Zone with subzones a and b, Corbisema archangelskiana Zone, Naviculopsis biapiculata Zone, Distephanus raupii Zone, Distephanus raupii-Corbisema triacantha Zone, and Corbisema triacantha mediana Zone.
\end{abstract}

\section{INTRODUCTION}

Previous studies of Southern Ocean silicoflagellate stratigraphy are limited in number and describe assemblages from Deep Sea Drilling Project (DSDP) Legs 28, 35, 36, and 71 (see Shaw and Ciesielski, 1983, for references), as well as a few additional sections from DSDP Legs 29 and 90. Of the previously described assemblages, only one comes from a section with paleomagnetic control (Holes 512 and 512A, middle Eocene; Shaw and Ciesielski, 1983). In addition, very few of these sequences have been correlated to standard low-latitude biostratigraphic zonal schemes, particularly those of the Paleogene. As a result of highly variable sedimentaccumulation rates, numerous disconformities, discontinuous drilling technique, and poor stratigraphic control, Southern Ocean biostratigraphy is still poorly defined.

Drilling by Ocean Drilling Program (ODP) Leg 114 in the subantarctic South Atlantic sector of the Southern Ocean (Fig. 1) recovered extensive sequences of Paleogene calcareous and siliceous sediment representing previously unrecovered parts of the Paleogene. These sequences offer the first opportunity to accurately calibrate calcareous and siliceous

\footnotetext{
${ }^{1}$ Ciesielski, P. F., Kristoffersen, Y., et al., 1991. Proc. ODP, Sci. Results, 114: College Station, TX (Ocean Drilling Program).

${ }^{2}$ Department of Geology, University of Florida, Gainesville, FL 32611.
}

biostratigraphic records of the southern high latitudes to the geomagnetic polarity time scale and to low-latitude zonal schemes. This opportunity is offered by the nearly complete record of the Paleogene, the presence of many low-latitude calcareous nannofossil and planktonic foraminifer index species, and a nearly complete composite paleomagnetic record of the Paleogene (Ciesielski, Kristoffersen, et al., 1988). Herein, the silicoflagellate assemblages of Leg 114 sedimentary sequences are examined, new taxa described, and a zonal scheme presented that is directly calibrated to the paleomagnetic time scale.

\section{PREPARATION OF SAMPLES AND METHODS OF STUDY}

All samples used in this study were collected by the author during Leg 114. All samples were processed for shorebased investigations using the following technique: raw samples were placed in $200-\mathrm{mL}$ beakers and heated with diluted hydrogen peroxide to disassociate the sediment and remove organic carbon. Hydrochloric acid was then added to dissolve any carbonate present in the samples. The undissolved residues were diluted with distilled water, centrifuged, and decanted to remove the acid. This procedure was repeated three times. Next, the samples were washed with sodium pyrophosphate, centrifuged, and decanted to remove a significant proportion of the clay present in the samples. This step was repeated until the sediment suspension obtained a neutral $\mathrm{pH}$. 


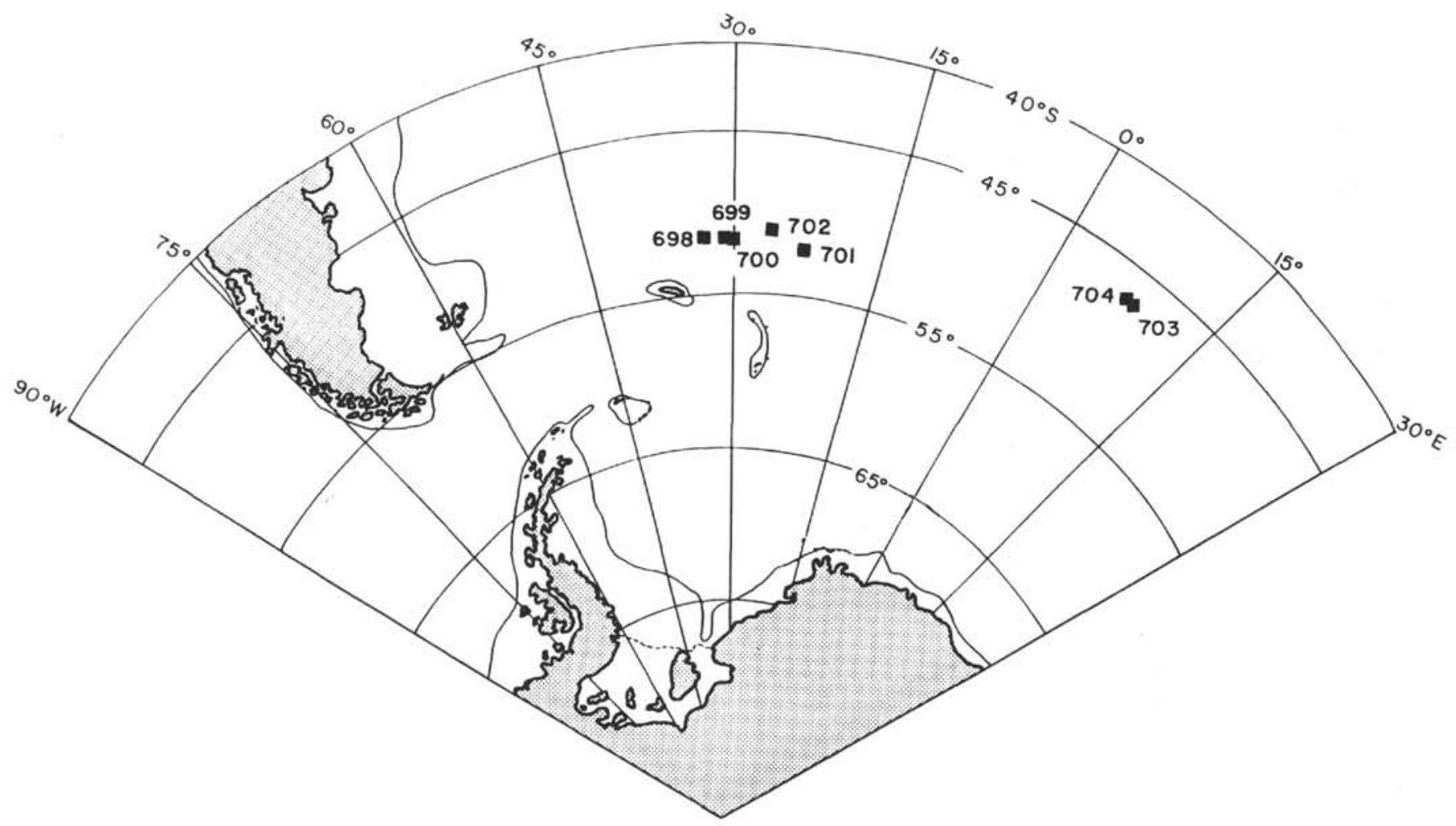

Figure 1. Location map showing the position of Leg 114 sites.

Processed residues were diluted with distilled water and stored in $50-\mathrm{mL}$ bottles.

Strewn slides of all samples were prepared by shaking bottles containing the sediment and water until all sediment was in suspension, and a small amount of the suspension was pipetted from the middle of the bottle. A few drops of the pipetted solution were placed on a glass slide and dispersed uniformly. After the slides dried, cover slips were mounted using Hyrax (n.d. $=1.71$ ) as the mounting medium. Quantitative analyses were made of silicoflagellate assemblages from Holes 698A, 700B, 702B, and 703A. From each prepared slide, counts were made of the entire slide or until 300 specimens were tabulated. Samples were considered barren if no complete or fragmented specimens were encountered in five traverses of the slide.

Because of the repetitive nature of text references to the paleomagnetic record and other microfossil zones, references to these works are provided here. The paleomagnetic polarity record of Holes 699A, 700B, and 703A is from two Hailwood and Clement reports (this volume), and that of Hole 702B is from Clement and Hailwood (this volume). References to the calcareous nannofossil zones of these holes are from Crux (this volume), or in the case of Okada and Bukry (1980) zones, they were identified by Madile and Monechi (this volume). Planktonic foraminifer zones were identified by Nocchi et al. (this volume). Diatom zones are referenced in the text.

This study does not present quantitative census data from Hole 699A; however, the stratigraphic ranges of index species were examined to determine the datums (P. F. Ciesielski, unpubl. data). It became necessary to establish these silicoflagellate datums in Hole 699A to accurately interpret the depth and extent of disconformities in sediments of similar age from Hole $703 \mathrm{~A}$ and the relationship of zones to the paleomagnetic polarity record. A correlation of all microfossil zonal schemes to the paleomagnetic record and a tabulation of datum events will be published (P. F. Ciesielski, unpubl. data).

\section{ZONATION AND HOLE STRATIGRAPHY}

The following section presents a silicoflagellate zonal scheme (Fig. 2) for the Paleogene and earliest Neogene. Presented within the discussion of the zones is also the representation of these zones and datums in the examined holes. Figures 3-9 present graphic representations of the ranges of silicoflagellate genera from Holes 700B (Figs. 3 and 4) and 703A (Figs. 5-9) by order of their lowest appearance. Tables present intervals barren of silicoflagellates in Holes 698A (Table 2), 700B (Table 4), 702B (Table 6), and 703A (Table 8). Quantitative census data are presented for Holes 698A (Table 1), 700B (Table 3), 702B (Table 5), and 703A (Table 7). The silicoflagellate zonation and stratigraphy is as follows.

\section{Corbisema hastata hastata Zone}

Definition. Interval from the initial Corbisema hastata hastata to the initial common occurrence of Corbisema disymmetrica disymmetrica (Ciesielski, herein).

Assemblage. Primary constituents of the zone in Hole 700B include Corbisema delicata, C. hastata hastata, Corbisema hastata globulata, Corbisema hastata miranda, Corbisema inermus inermus, and Corbisema constricta constricta.

Datums. Only Corbisema praedelicata $=63.2 \mathrm{Ma}$, first-occurrence datum (FAD) $C$. constricta constricta $=63.15 \mathrm{Ma}$, last-occurrence datum $(\mathrm{LAD}) C$. delicata $=63.0 \mathrm{Ma}$, and FAD Corbisema hastata alta $=63.0 \mathrm{Ma}$.

Remarks. Corbisema hastata hastata has been noted elsewhere to occur within the Upper Cretaceous; therefore, this zone encompasses an as yet undetermined portion of the Upper Cretaceous and the lowermost Paleocene between 66.4 and $\sim 62.9 \mathrm{Ma}$.

Correlation. The initial $C$. hastata hastata is unrecognized because of opal diagenesis in the lowermost Paleocene. The oldest 


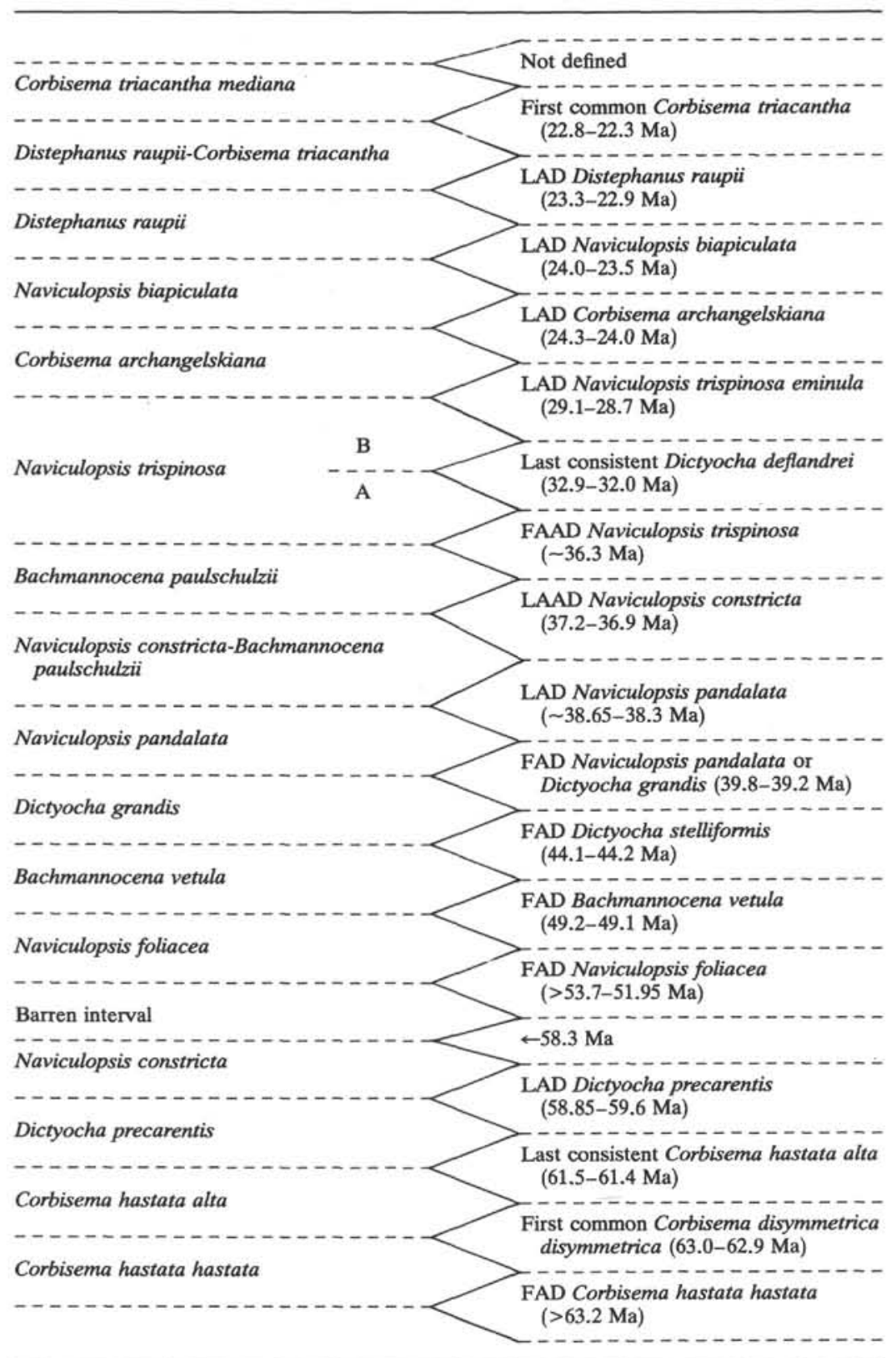

Figure 2. Paleocene to lower Miocene silicoflagellate zones, boundary definitions, and ages.

sample of the zone recognized above the diagenetic zone is in Subchron $\mathrm{C} 27 \mathrm{~N}$, within the planktonic foraminifer P1c Zone and calcareous nannofossil Prinsius martini Zone. The top of the zone occurs immediately above the Subchron C26R/C27N boundary (62.9 $\mathrm{Ma}$ ), within the planktonic foraminifer P2 Zone, and brackets the boundary between the calcareous nannofossil Prinsius bisulcus and $P$. martini Zones.

Interval. Sample 114-700B-32R-5, 40-42 cm, to an upper boundary between Samples 114-700B-32R-3, $40 \mathrm{~cm}$, and 114-700B-32R-2, 37 $\mathrm{cm}$ (298.40-296.85 $\mathrm{m}$ below seafloor-mbsf).

\section{Corbisema hastata alta Zone}

Definition. Interval from the initial common occurrence of Corbisema disymmetrica disymmetrica to the last consistent occurrence of Corbisema hastata alta (Ciesielski, herein).

Assemblage. Corbisema disymmetrica disymmetrica dominates the lowermost portion of the zone. The remainder of the zone is typified by increasing diversity of Corbisema. The most common species include Corbisema hastata globulata, Corbisema hastata hastata, Corbisema inermus inermus, $C$. hastata alta, and Corbisema glezerae. Dictyocha sp. 2 and Naviculopsis primativa are abundant near the top of the zone.

Datums. FAD Corbisema disymmetrica crenulata $=62.9 \mathrm{Ma}$, FAD Corbisema toxeuma $=62.9 \mathrm{Ma}$, first consistent Corbisema constricta constricta $=62.8 \mathrm{Ma}, \mathrm{LAD} C$. disymmetrica crenulata $=$ $62.73 \mathrm{Ma}, \mathrm{FAD}$ Corbisema camara $=62.73 \mathrm{Ma}, \mathrm{FAD}$ C. glezerae $=$ 62.73 Ma, FAD Dictyocha precarentis (earliest occurrence of Dictyocha $)=62.73 \mathrm{Ma}$, FAD Corbisema animoparallela $=62.66 \mathrm{Ma}, \mathrm{FAD}$ Corbisema archangelskiana $=62.66 \mathrm{Ma}, \mathrm{FAD}$ Corbisema falklandensis $=62.66 \mathrm{Ma}$, FAD Dictyocha sp. $2=62.66 \mathrm{Ma}$, FAD Corbisema hastata cunicula $=62.3 \mathrm{Ma}, \mathrm{FAD}$ Corbisema triacantha lepidospinosa $=61.7 \mathrm{Ma}$, FAD Corbisema constricta spinosa $=61.6 \mathrm{Ma}$, and only occurrence of Naviculopsis primativa (earliest occurrence of Naviculopsis $)=61.5 \mathrm{Ma}$.

Remarks. Silicoflagellate diversity increases greatly throughout this zone and greatly exceeds that of the earliest Paleocene. The first 


\begin{tabular}{rlrl}
\hline & $=$ Very rare & & $(1-2$ counts $)$ \\
0 & $=$ Rare & & $(3-6$ counts $)$ \\
$:$ & $=$ Sparse & & $(7-14$ counts $)$ \\
$O$ & $=$ Frequent & & $(15-30$ counts $)$ \\
$O$ & $=$ Common & & $(31-60$ counts $)$ \\
& $=$ Abundant & & $(61-300$ counts $)$ \\
$?$ & $=$ Questionably present \\
& $=$ Not present &
\end{tabular}

\begin{tabular}{|c|c|c|c|c|c|c|c|c|c|c|}
\hline $\begin{array}{l}\text { Core, section, } \\
\text { interval }(\mathrm{cm})\end{array}$ & 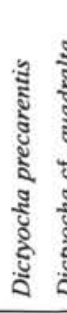 & 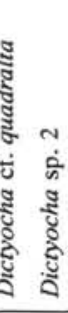 & 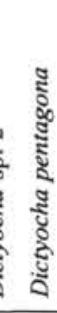 & 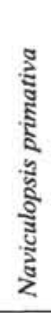 & 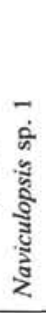 & 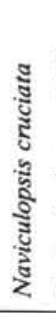 & 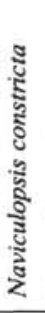 & 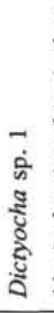 & 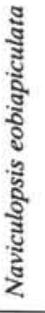 & \\
\hline \multicolumn{11}{|l|}{$114-700 \mathrm{~B}$. } \\
\hline $26 \mathrm{R}-2,78-80$ & . & . & . & & & & 0 & & & $26 \mathrm{R}-2,78-80$ \\
\hline $27 \mathrm{R}-1,60-62$ & & . & . & . & . & . & (-) & . & 1 & $27 \mathrm{R}-1,60-62$ \\
\hline $28 \mathrm{R}-1,116-118$ & (-) & . & . & . & . & . & 0 & . & . & $28 \mathrm{R}-1,116-118$ \\
\hline $28 \mathrm{R}-2,116-118$ & 8 & & . & . & . & . & 0 & 0 & . & $28 \mathrm{R}-2,116-118$ \\
\hline $28 \mathrm{R}-3,116-118$ & 8 & . & . & . & . & . & 1 & 0 & . & $28 \mathrm{R}-3,116-118$ \\
\hline $28 \mathrm{R}-4,116-118$ & 8 & (.) & ). & . & . & . & & & & $28 \mathrm{R}-4,116-118$ \\
\hline $29 \mathrm{R}-1,39-40$ & 8 & . & . & . & . & . & & ! & . & $29 \mathrm{R}-1,39-40$ \\
\hline $29 \mathrm{R}-2,37-38$ & 8 & . & 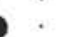 & . & . & . & 1 & . & . & $29 \mathrm{R}-2,37-38$ \\
\hline $29 \mathrm{R}-\mathrm{CC}$ & 0 & . & 0 & . & . & . & . & . & . & $29 \mathrm{R}-\mathrm{CC}$ \\
\hline 30R-1, 99-101 & 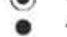 & & & . & . & 0 & . & . & . & $30 \mathrm{R}-1,99-101$ \\
\hline $30 \mathrm{R}-2,118-120$ & . & & & e & 0 & . & . & . & . & $30 \mathrm{R}-2,118-120$ \\
\hline $30 \mathrm{R}-3,106-108$ & 0 & . & & & & . & . & . & . & 30R-3, 106-108 \\
\hline $30 \mathrm{R}-4,109-111$ & ○̆ & 0 & & . & . & . & . & . & . & $30 \mathrm{R}-4,109-111$ \\
\hline $30 \mathrm{R}-5,111-113$ & & & & 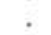 & . & . & . & . & . & $30 \mathrm{R}-5,111-113$ \\
\hline $31 \mathrm{R}-1,29-31$ & - & Ŏ & ! & . & . & . & . & . & . & $31 \mathrm{R}-1,29-31$ \\
\hline $31 \mathrm{R}-2,9-11$ & $\bullet$ & . ๑ & . & . & . & . & . & & . & $31 \mathrm{R}-2,9-11$ \\
\hline $31 \mathrm{R}-3,9-11$ & . & o & . & . & . & . & . & . & . & $31 \mathrm{R}-3,9-11$ \\
\hline $31 \mathrm{R}-4,9-11$ & 0 & . & . & . & . & . & . & & & $31 \mathrm{R}-4,9-11$ \\
\hline $31 R-5,8-10$ & & & 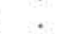 & . & . & . & . & . & . & $31 \mathrm{R}-5,8-10$ \\
\hline $31 \mathrm{R}-6,36-38$ & . & & 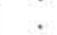 & . & . & . & . & & . & $31 \mathrm{R}-6,36-38$ \\
\hline $31 \mathrm{R}-7,40-42$ & 0 & . & . & . & . & . & . & . & . & $31 R-7,40-42$ \\
\hline $32 \mathrm{R}-1,38-40$ & . & . & . & $\therefore$ & . & . & . & . & . & $32 \mathrm{R}-1,38-40$ \\
\hline $32 \mathrm{R}-2,35-37$ & 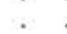 & . & . & . & . & & & & . & $32 \mathrm{R}-2,35-37$ \\
\hline $32 R-3,40-42$ & . & . & . & . & . & . & . & . & 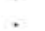 & $32 \mathrm{R}-3,40-42$ \\
\hline $32 \mathrm{R}-4,42-44$ & 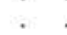 & . & . & . & . & . & . & . & . & $32 \mathrm{R}-4,42-44$ \\
\hline $32 R-5,40-42$ & : & . & . & . & . & . & . & . & . & $32 R-5,40-42$ \\
\hline
\end{tabular}

Figure 3. Range chart of graphic abundances of Dictyocha and Naviculopsis species from Hole 700B in order of lowest appearance.

occurrence of Dictyocha is noted in the early portion of the zone, whereas Naviculopsis evolved from Corbisema late in the zone.

Correlation. The top of the zone occurs within the lower portion of foraminifer Zone P4 and at or slightly above the calcareous nannofossil Fasiculithus tympaniformis group Zone. This zone occurs entirely within Subchron C26R with an estimated age of $61.45 \mathrm{Ma}$ for its upper boundary. Based upon the previously estimated age for the base of the zone, the zonal age is approximately 62.9 to $61.45 \mathrm{Ma}$.

Interval. The base of the zone is between Samples 114-700B-32R$3,40 \mathrm{~cm}$, and 114-700B-32R-2, $37 \mathrm{~cm}(298.40-296.85 \mathrm{mbsf})$, and the upper boundary lies between Samples 114-700B-30R-2, $118 \mathrm{~cm}$, and 114-700B-30R-1, $101 \mathrm{~cm}(278.68-277.01 \mathrm{mbsf})$.

\section{Dictyocha precarentis Zone}

Definition. Interval from the last consistent occurrence of Corbisema hastata alta to the last appearance of Dictyocha precarentis (Ciesielski, herein).

Assemblage. Assemblages of the Dictyocha precarentis Zone are dominated by Corbisema hastata hastata, Corbisema hastata globulata, Corbisema hastata cunicula, Corbisema inermus inermus, Corbisema constricta constricta, Corbisema glezerae, and D. precarentis.

Datums. Only occurrence of Naviculopsis cruciata $=61.4 \mathrm{Ma}, \mathrm{LAD}$ Corbisema triacantha lepidospinosa $=60.8 \mathrm{Ma}, \mathrm{FAD}$ Corbisema cuspis $=60.8 \mathrm{Ma}$, first consistent Corbisema naviculoidea $=60.5 \mathrm{Ma}, \mathrm{FAD}$ Naviculopsis constricta $=60.5 \mathrm{Ma}, \mathrm{FAD}$ Corbisema bimucronata bimucronata $=60.4 \mathrm{Ma}$, LAD Corbisema constricta spinosa $=60.04$
Ma, LAD Corbisema animoparallela $=60.13 \mathrm{Ma}$, LAD Dictyocha $\mathrm{sp} .2$ $=59.8 \mathrm{Ma}$, and $\mathrm{LAD} C$. naviculoidea $=59.2 \mathrm{Ma}$.

Remarks. Numerous datums occur within the zonal interval; however, the LAD of Dictyocha precarentis was selected as the upper boundary because of its abundant and consistent occurrence throughout the interval and its abrupt disappearance.

Correlation. The zone occurs entirely within foraminifer Zone P4 and is directly correlated to range from within paleomagnetic Subchrons $\mathrm{C} 25 \mathrm{~N}$ or $\mathrm{C} 25 \mathrm{R}$ to $\mathrm{C} 26 \mathrm{R}$. The upper boundary of the zone occurs within the calcareous nannofossil Heliolithus riedellii Zone (NP8). The depth uncertainty of the top of the zone brackets the base of Subchron C25N (59.24 Ma), but is still within the uppermost $H$. riedellii Zone $($ top $=59.1 \mathrm{Ma}$ ). The upper boundary of the zone is calculated to have an age ranging from 59.6 to $58.9 \mathrm{Ma}$, based on the assumption of constant sedimentation rates between adjacent paleomagnetic boundaries. The estimated age range for the zone is approximately 61.45 to $59.2 \mathrm{Ma}$.

Interval. The base of the zone lies between Samples 114-700B$30 \mathrm{R}-2,118 \mathrm{~cm}$, and $114-700 \mathrm{~B}-30 \mathrm{R}-1,101 \mathrm{~cm}(278.68-277.01 \mathrm{mbsf})$; the upper boundary of the zone lies between Samples 114-700B-28R-1, $116 \mathrm{~cm}$, and 114-700B-27R-1, $62 \mathrm{~cm}$ (258.16-248.12 mbsf).

\section{Naviculopsis constricta Zone}

Definition. Interval from the last Dictyocha precarentis to the initial appearance of Naviculopsis foliacea (Ciesielski, herein).

Assemblage. Principal elements of the lower portion of the zone recognized in Hole 700B include Corbisema hastata hastata, Corbisema constricta constricta, Corbisema glezerae, and Corbisema hastata cunicula.

Datums. Several species disappear between Samples 114-700B27R-1, 60-62 cm, and 114-700B-26R-2, 78-80 cm; however, these disappearances immediately precede complete opal diagenesis above this sample and are most likely due to poor preservation in the later sample.

Remarks and Correlation. The lower portion of this zone is represented in Hole 700B (base of zone to $58.3 \mathrm{Ma}$ ); however, the upper portion of the zone has not yet been recovered in the Southern Ocean as a result of the absence of siliceous-bearing sediments of earliest Eocene age. The only biosiliceous early Eocene sediment recovered comes from Sample 114-698A-3R-1, 40-42 cm. This sample contains Naviculopsis foliacea and thus provides a minimum age for the boundary between the $N$. constricta Zone and the $N$. foliacea Zone. The sample from Hole 698A containing $N$. foliacea is assigned to foraminifer Zones P8-9 and occurs between samples bracketing the Discoaster sublodoensis Zone (NP14) and Discoaster lodoensis Zone (NP13). The stratigraphic overlap of these zones is in Chron C22, which is in agreement with the occurrence of $N$. foliacea in Hole 698A above two foraminifer datums calibrated elsewhere to Chron $\mathrm{C} 22$ (FAD Morozovella crater and LAD Acarinina triplex; P. F. Ciesielski, unpubl. data). Based on these findings, the upper boundary for the $N$. constricta Zone has a minimum age of 51.95 to $53.7 \mathrm{Ma}$. The maximum age range for the zone is from 59.6 to $51.95 \mathrm{Ma}$, and the minimum age range is from 58.85 to $53.7 \mathrm{Ma}$.

Interval. The lower boundary of the zone lies between Samples 114-700B-28R-1, $116 \mathrm{~cm}$, and 114-700B-27R-1, $62 \mathrm{~cm}$ (258.16-248.12 $\mathrm{cm})$. The upper boundary is unrecognized but is older than Sample 114-698A-3R-1, 40-42 cm.

\section{Naviculopsis foliacea Zone}

Definition. Interval from the initial Naviculopsis foliacea to the initial occurrence of Bachmannocena vetula (Ciesielski, herein).

Assemblage. Only Samples 114-698A-3R-1, 40-42 cm, and 114 $702 \mathrm{~B}-18 \mathrm{X}-4,40-42 \mathrm{~cm}$, were recovered representing this zone. The older of these samples contains the oldest noted occurrence of Bachmannocena, although its initial appearance may have been earlier in as yet unrepresented portions of the Naviculopsis constricta and $N$. foliacea Zones. Among the early representatives of this genus are Bachmannocena connudata, Bachmannocena apiculata inflata, and Bachmannocena paulschulzii var. 1. Other constituents of the zone include $N$. constricta, $N$. foliacea, Naviculopsis eobiapiculata var. 1, Corbisema apiculata, Corbisema hastata globulata, and Dictyocha bryonalis.

Remarks. The upper boundary of the zone occurs in the lower opal-bearing portion of Hole $702 \mathrm{~B}$, where preservation of biogenic opal is poor to fair. As a result of poor preservation, the base of this 


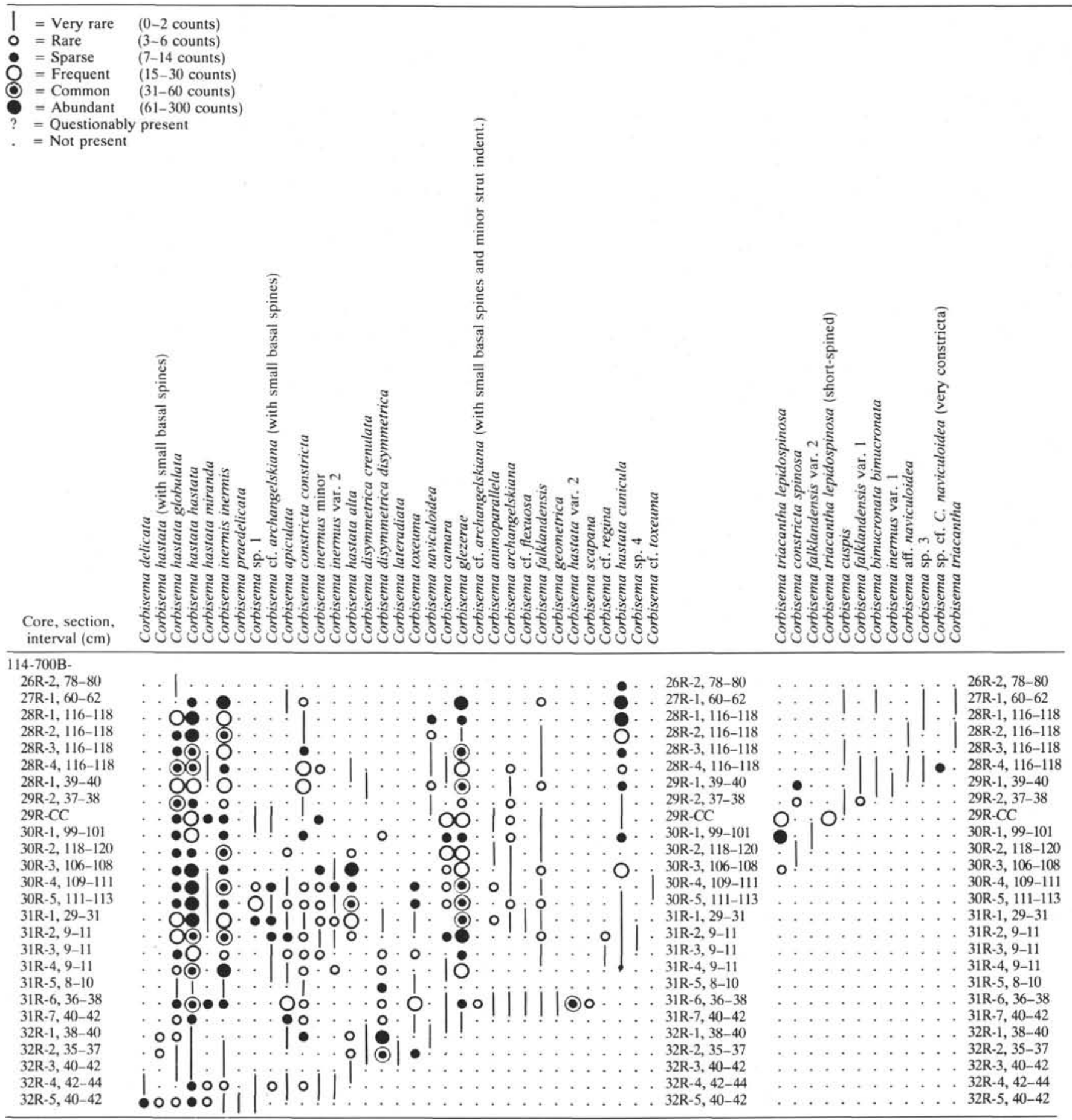

Figure 4. Range chart of graphic abundances of Corbisema species from Hole 700B in order of lowest appearance.

zone should be considered a minimum age until better preserved lower middle Eocene sediments are recovered.

Correlation. The upper boundary of the zone occurs within the Discoaster sublodoensis Zone and within upper foraminifer P10 Zone. In addition, this boundary is directly correlated to the upper portion of Subchron $\mathrm{C} 21 \mathrm{~N}$. The age of the upper boundary of the zone based upon sedimentation rates within Subchron $\mathrm{C} 21 \mathrm{~N}$ is $49.20-48.96 \mathrm{Ma}$. This age is in agreement with the boundary 1-4 m below the LAD Planorotalites pseudoscitulus elongatus ( $48.8 \mathrm{Ma}$; P. F. Ciesielski, unpubl. data); therefore, its age is taken to be $\sim 49.1 \mathrm{Ma}$. The presently known age of the zone ranges from $51.95-53.7$ to $\sim 49.1 \mathrm{Ma}$; however, the true base of the zone may be older, as sediments between the observed base and those with an age of 58.3 Ma were barren of silicoflagellates.

Interval. The lower boundary is unrecognized but is older than Sample 114-698A-3R-1, 40-42 cm (51.95-53.7 Ma). The upper boundary of the zone occurs between Samples 114-702B-18X-2, $42 \mathrm{~cm}$, and 114-702B-18X-4, $40 \mathrm{~cm}$ (160.22-163.22 mbsf).

\section{Bachmannocena vetula Zone}

Definition. Interval from the initial occurrence of Bachmannocena vetula to the initial occurrence of Dictyocha stelliformis (Ciesielski, herein). 


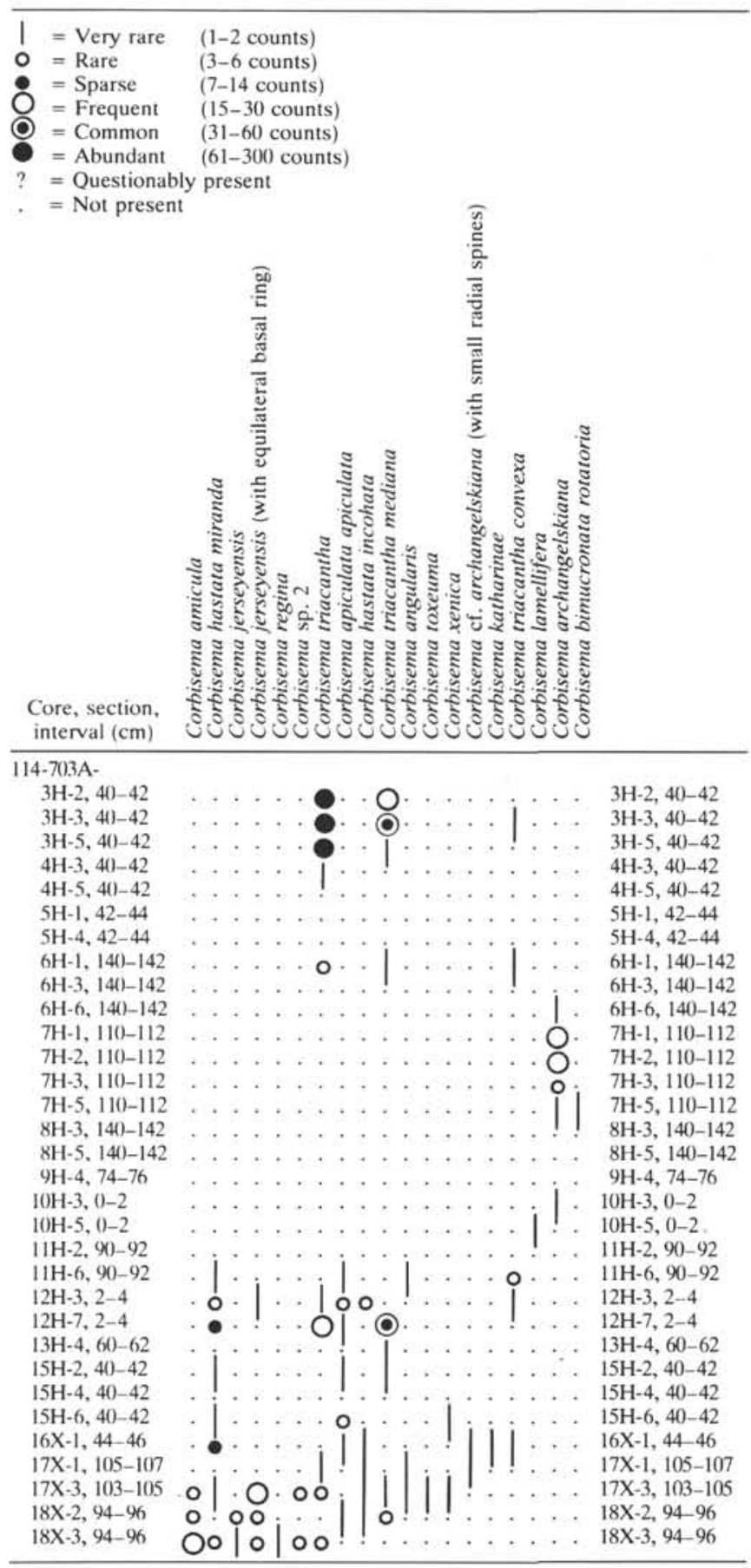

Figure 5. Range chart of graphic abundances of Corbisema species from Hole $703 \mathrm{~A}$ in order of lowest appearance.

Assemblage. Twenty-seven species were noted within the poorly preserved sediments of the zone in Hole 702B. Occurrences are generally sporadic as a result of dissolution. The most consistently occurring species are Naviculopsis constricta and Bachmannocena vetula, although they are absent in the very poorly preserved upper portion of the zone.

Datums. LAD Dictyocha bryonalis $=\sim 49.1$ to $48.3 \mathrm{Ma}, \mathrm{FAD}$ ? Bachmannocena paulschulzii $=45.85 \mathrm{Ma}$, and LAD Corbisema constricta constricta $=45.2 \mathrm{Ma}$.

Remarks. Although preservation of silicoflagellates in this zone is poor, sediments of this zone are the first of their age from the

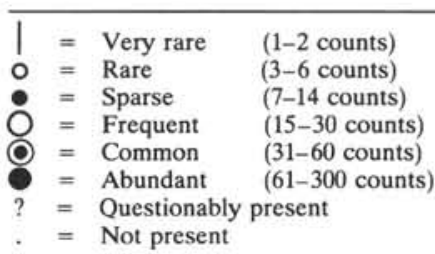

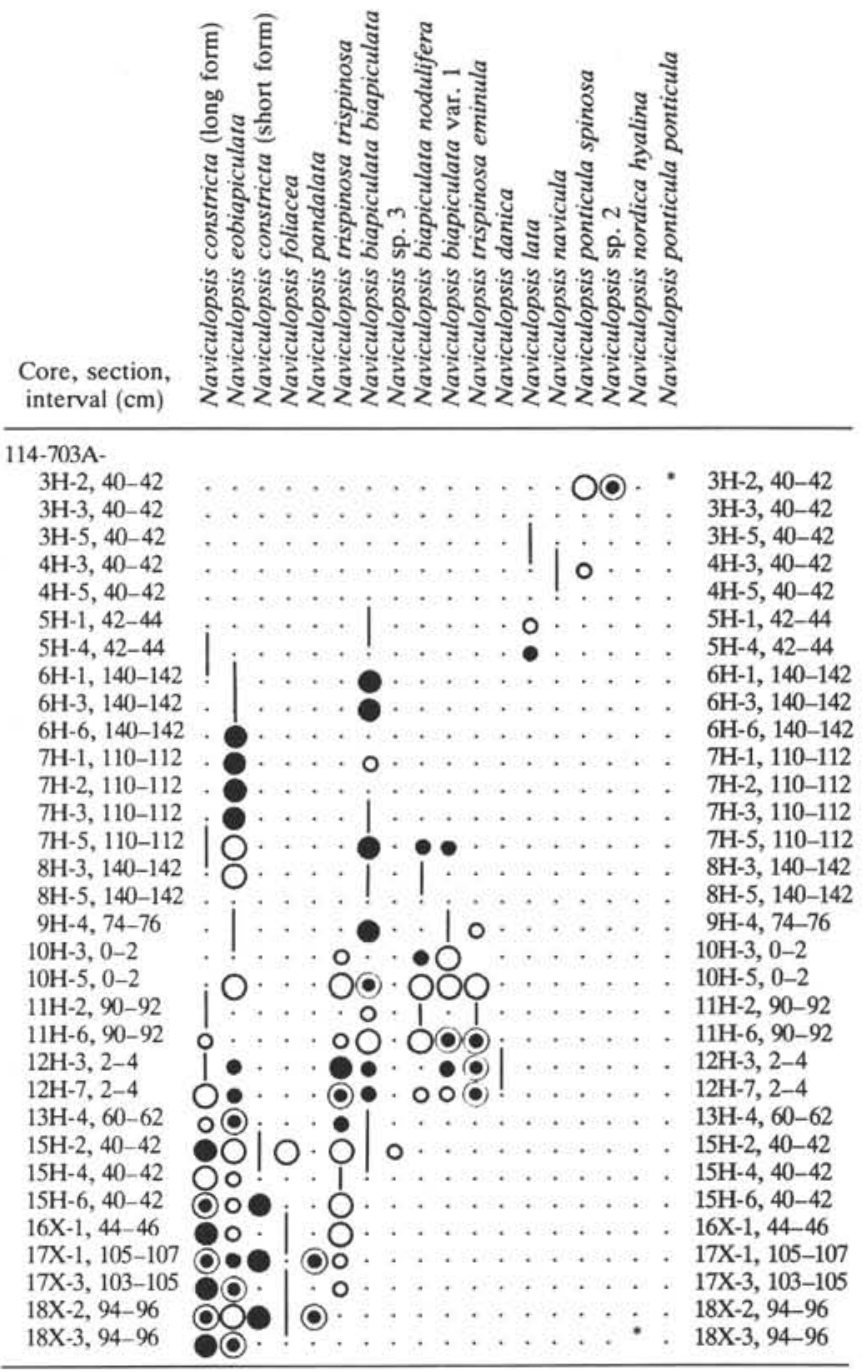

Figure 6. Range chart of graphic abundances of Naviculopsis species from Hole $703 \mathrm{~A}$ in order of lowest appearance. ${ }^{*}=$ very rare, found only after completion of census count of 300 specimens.

Southern Ocean to bear silicoflagellates. This zone is one of few middle Eocene sections anywhere with these fossils described.

Correlation. The upper zonal boundary occurs within foraminifer Zones P12-13. The bracketing depths for the boundary include the upper Nannotetrina fulgens Zone and possibly a portion of the lower Chiasmolithus solitus Zone. Direct correlation of the top of the zone with the paleomagnetic record of Hole 702B places the boundary in upper Subchron C19R, just below the base of Subchron C19N (44.06 Ma). Shaw and Ciesielski (1983) found D. stelliformis at the base of Hole 512A, which was also directly correlated to within subchron C19R and within the Discoaster bifax Subzone (CP14a) of the middle Eocene Reticulofenestra umbilica Zone. Based upon the assumption of constant sedimentation rates in Hole 702B between the base of Subchron C19N and the top of Subchron C20N, the age of the upper zonal boundary ranges from 44.07 to $44.21 \mathrm{Ma}$ (mean age $=44.14 \mathrm{Ma}$ ). 


\begin{tabular}{rlrl}
\hline & $=$ Very rare & & $(1-2$ counts $)$ \\
0 & $=$ Rare & & $(3-6$ counts $)$ \\
& $=$ Sparse & & $(7-14$ counts $)$ \\
$O$ & $=$ Frequent & & $(15-30$ counts $)$ \\
$O$ & $=$ Common & $(31-60$ counts $)$ \\
$?$ & $=$ Abundant & $(61-300$ counts $)$ \\
$?$ & $=$ Questionably present \\
& $=$ Not present &
\end{tabular}

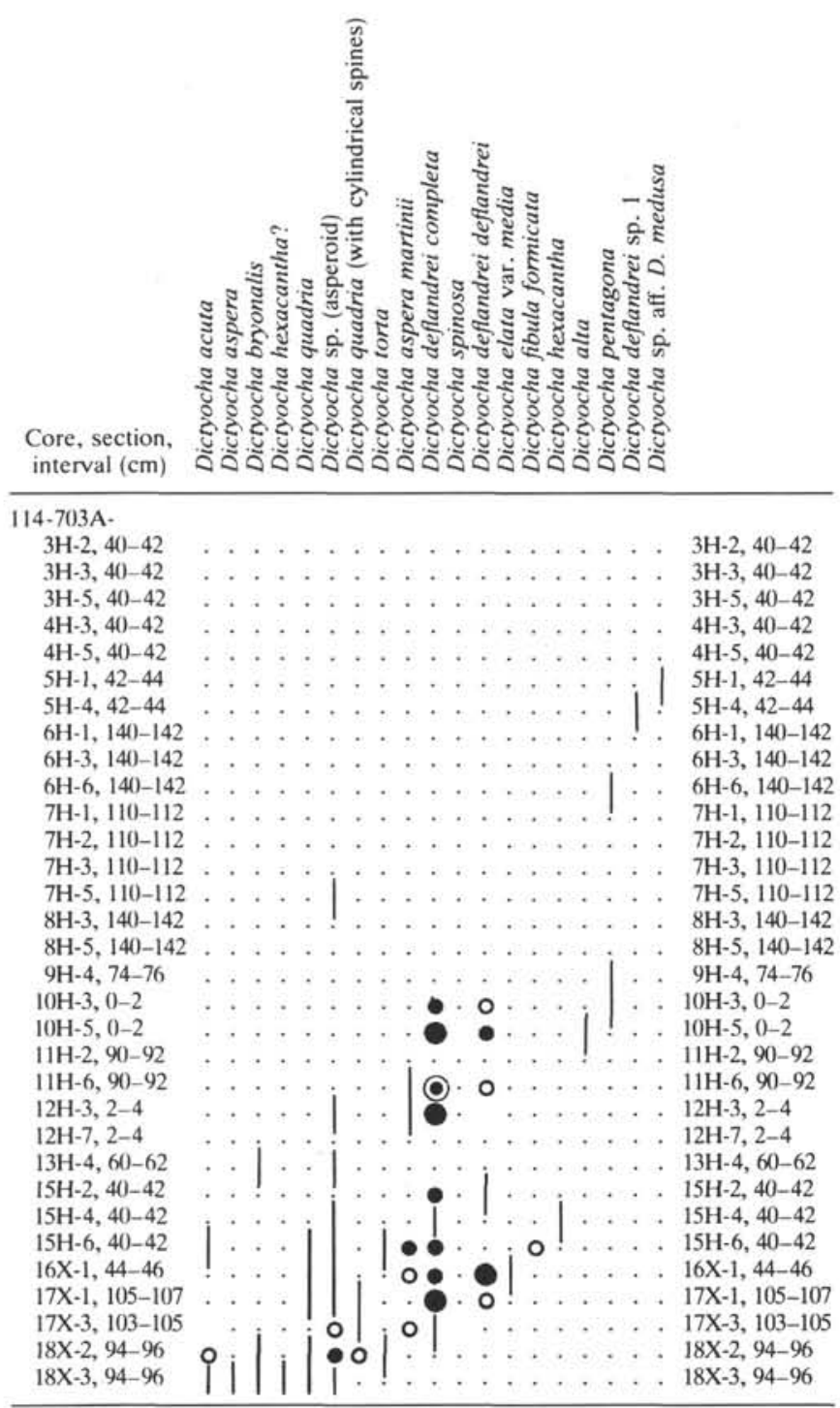

Figure 7. Range chart of graphic abundances of Dictyocha species from Hole $703 \mathrm{~A}$ in order of lowest appearance.

Interval. Poor preservation in Hole 702B prevents certain placement of the base of the zone; however, the initial appearance of $B$. vetula is noted between Samples 114-702B-18X-2, $42 \mathrm{~cm}$, and 114 $702 \mathrm{~B}-18 \mathrm{X}-4,40 \mathrm{~cm}(160.22-163.20 \mathrm{mbsf})$. The upper limit of the zone is recognized between Samples 114-702B-10X-5, $140 \mathrm{~cm}$, and 114702B-10X-3, $142 \mathrm{~cm}$ (89.70-86.72 mbsf).

\section{Dictyocha grandis Zone}

Definition. Interval from the initial occurrence of Dictyocha stelliformis to the last occurrence of Dictyocha grandis or first consistent occurrence of Naviculopsis pandalata (Shaw and Ciesielski, 1983; emended, herein).

Assemblage. The assemblage of the Dictyocha grandis Zone is of limited diversity because of silica diagenesis, which has removed dissolution-susceptible species. The portion of the zone studied in detail (Samples 114-702B-8X-3, 40-42 cm, to 114-702B-10X-3, 140$142 \mathrm{~cm}$ ) is dominated by the dissolution-resistent species Dictyocha grandis and D. stelliformis. Among other species present are Naviculopsis constricta, Naviculopsis eobiapiculata, Naviculopsis pandalata (rare), Naviculopsis trispinosa trispinosa (rare), Dictyocha quadria, and Bachmannocena paulschulzii.

Remarks. Shaw and Ciesielski (1983) defined the Dictyocha grandis Zone by the total range of the name-bearing species. Their reference section for the zone is Holes 512 and $512 \mathrm{~A}$, where the the lowermost and uppermost portions of the zone are truncated by disconformities, with only Subchron $\mathrm{C} 18 \mathrm{~N}$ through a portion of Subchron C19R represented. Although preservation of the middle Eocene at Hole 702B is poor in comparison to that at Site 512, the middle Eocene section is more complete and is the basis of a revision of the $D$. grandis Zone.

The initial appearance of $D$. stelliformis is substituted for the initial $D$. grandis as the base of the zone. In Hole $702 \mathrm{~B}$, the initial appearance of $D$. stelliformis is abrupt and abundant; it went unrecorded in Hole 512A because the lower portion of its range was terminated by a disconformity. The last occurrence of $D$. stelliformis is maintained as the top of the $D$. stelliformis Subzone, and the initial occurrence of Bachmannocena apiculata apiculata is also maintained as the top of the D. stelliformis-B. apiculata Subzone. The top of the $B$. apiculata Subzone and the top of the $D$. grandis Zone are revised from Shaw and Ciesielski (1983) to be defined by the last occurrence of $D$. grandis or the first consistent occurrence of $N$. pandalata. The dual datum definition for the top of the zone is a consequence of the scarcity of $D$. grandis in its upper range. In sections where $D$. grandis is rare, the top of the zone may be recognized by the first consistent occurrence of $N$. pandalata. In Hole $702 \mathrm{~B}$ the last noted $D$. grandis occurs between 43.06 and $39.72 \mathrm{mbsf}$ and the initial consistent occurrence of $N$. pandalata occurs between 42.70 and $39.72 \mathrm{mbsf}(\mathrm{P}$. F. Ciesielski, unpubl. data), therefore, mean depths for these datums are virtually the same ( 41.39 and $41.21 \mathrm{mbsf}$ ).

Correlation. The base of the zone is directly correlated to the paleomagnetic record of Hole 702B to occur within upper Subchron C19R (44.21-44.07 Ma). This placement indicates that the oldest portion of the zone recognized in Hole 512A (Shaw and Ciesielski, 1983), also in Subchron C19R, is near the base of the zone. The position of this datum is within the interval designated as the foraminifer P12-13 Zones and in the unstudied interval between the Chiasmolithus solitus Zone and Nannotetrina fulgens Zone.

The top of the D. stelliformis Subzone occurs in lower Subchron C18R of Hole 702B (43.4 Ma), but occurs in uppermost Subchron C19R in Hole 512, suggesting some minor diachroneity in the subantarctic South Atlantic. In Hole 702B this boundary also occurs within the the foraminifer P12-13 Zones and within the uppermost $N$. fulgens Zone or lowermost $C$. solitus Zone.

The top of the D. stelliformis-B. apiculata Subzone is not recognized in Hole 702B (a consequence of dissolution); however, direct correlation to the paleomagnetic polarity record of Hole 512 (Shaw and Ciesielski, 1983) places this boundary in lower Subchron C18R.

The upper boundary of the zone occurs in an interval of Hole 702B without paleomagnetic control and above the interval of this quantitative study. Examination of the upper portion of Hole 702B was made by this author to determine the last occurrence of $D$. grandis, however, a quantitative census of this interval can not be presented herein. The placement of this datum is within the lower portion of foraminifer Zone P15 and lower calcareous nannofossil Chiasmolithus oamaruensis Zone. Further constraining the upper age of the zone is the age of the initial consistent $N$. pandalata, co-marker for the top of the $D$. grandis Zone, which is found above a disconformity in Hole $703 \mathrm{~A}$. This datum occurs near but below the Subchron C16N/C16R boundary $(39.24 \mathrm{Ma})$ in Hole $703 \mathrm{~A}$ and above the FAD of $C$. oamaruensis (39.8 Ma) in Holes 703A and 702B. These stratigraphic constraints place the upper boundary of the $D$. grandis Zone within Subchron C16R to uppermost Subchron C17N ( 39.24-39.8 Ma).

Interval. The $D$. grandis Zone in Hole $702 \mathrm{~B}$ has its base between Samples 114-702B-10X-3, $142 \mathrm{~cm}$, and 114-702B-10X-5, $140 \mathrm{~cm}$ (89.70-86.72 mbsf). The top of the D. stelliformis Subzone occurs between Samples 114-702B-10X-1, $140 \mathrm{~cm}$, and 114-702B-9X-5, 120 $\mathrm{cm}$ (83.70-80.0 mbsf). The D. stelliformis $-B$. apiculata Subzone and $B$. apiculata Subzone are undifferentiated because of the absence of B. apiculata apiculata, apparently as a result of dissolution. The top 

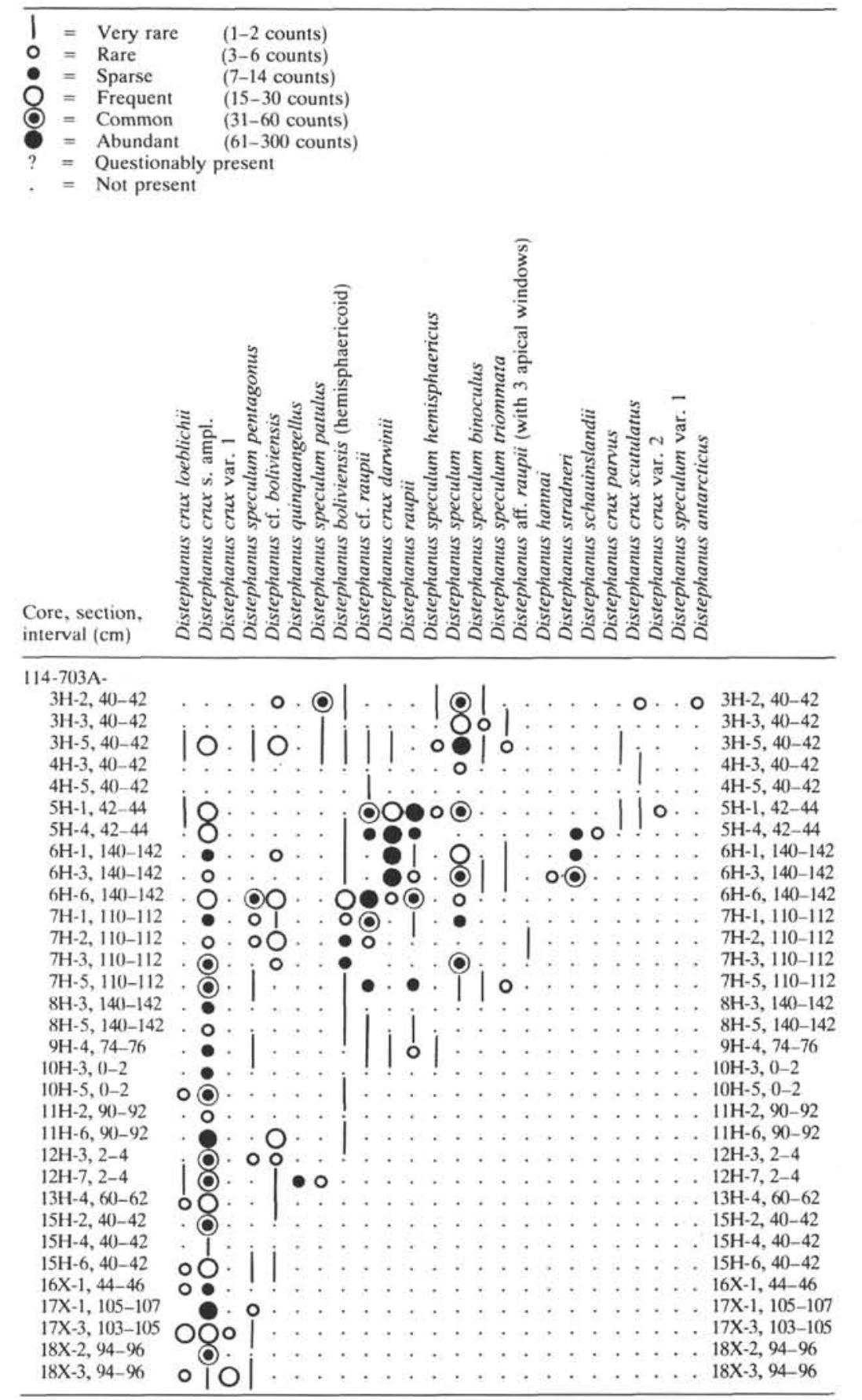

Figure 8. Range chart of graphic abundances of Distephanus species from Hole 703A in order of lowest appearance.

of the zone occurs between Samples 114-702B-5X-4, $42 \mathrm{~cm}$, and $114-702 \mathrm{~B}-5 \mathrm{X}-6,40 \mathrm{~cm}(39.72-42.70 \mathrm{~cm})$.

The $D$. stelliformis Subzone of the $D$. grandis Zone was also recognized in Sample 114-703A-19X-CC by Ling during shipboard investigations (Ciesielski, Kristoffersen, et al., 1988, p. 566). The remainder of the zone is missing at this site.

\section{Naviculopsis pandalata Zone}

Definition. Interval from the initial consistent occurrence of $\mathrm{Nav}$ iculopsis pandalata or last occurrence of Dictyocha grandis to the last occurrence of $N$. pandalata (Ciesielski, herein).

Assemblage. This zone is characterized by exceptionally abundant and diverse assemblages of silicoflagellates. More than 40 species were noted within the zone. Silicoflagellates are so abundant that 300 specimens may be counted in only a few traverses of the slide. Naviculopsis species are extremely abundant and account for the greatest proportion of the assemblage. The most abundant species include Naviculopsis constricta, N. pandalata, Naviculopsis eobiapiculata, Distephanus crux, and Distephanus crux loeblichii. Rare occurrences of the lower latitude marker species Dictyocha hexacantha were noted in Hole 703A.

Datums. LAD Corbisema jerseyensis $=38.7 \mathrm{Ma}, \mathrm{LAD}$ Bachmannocena apiculata monolineata $=38.7 \mathrm{Ma}$, LAD Corbisema amicula $=38.7 \mathrm{Ma}$, FAD Dictyocha deflandrei deflandrei $=38.7 \mathrm{Ma}, \mathrm{LAD}$ Corbisema regina $=\mathrm{C16R}(39.24 \mathrm{Ma})$, FAD Bachmannocena apiculata evexa $=\mathrm{C} 16 \mathrm{R}, \mathrm{FAD}$ Corbisema triacantha mediana $=\mathrm{C} 16 \mathrm{R}$ 

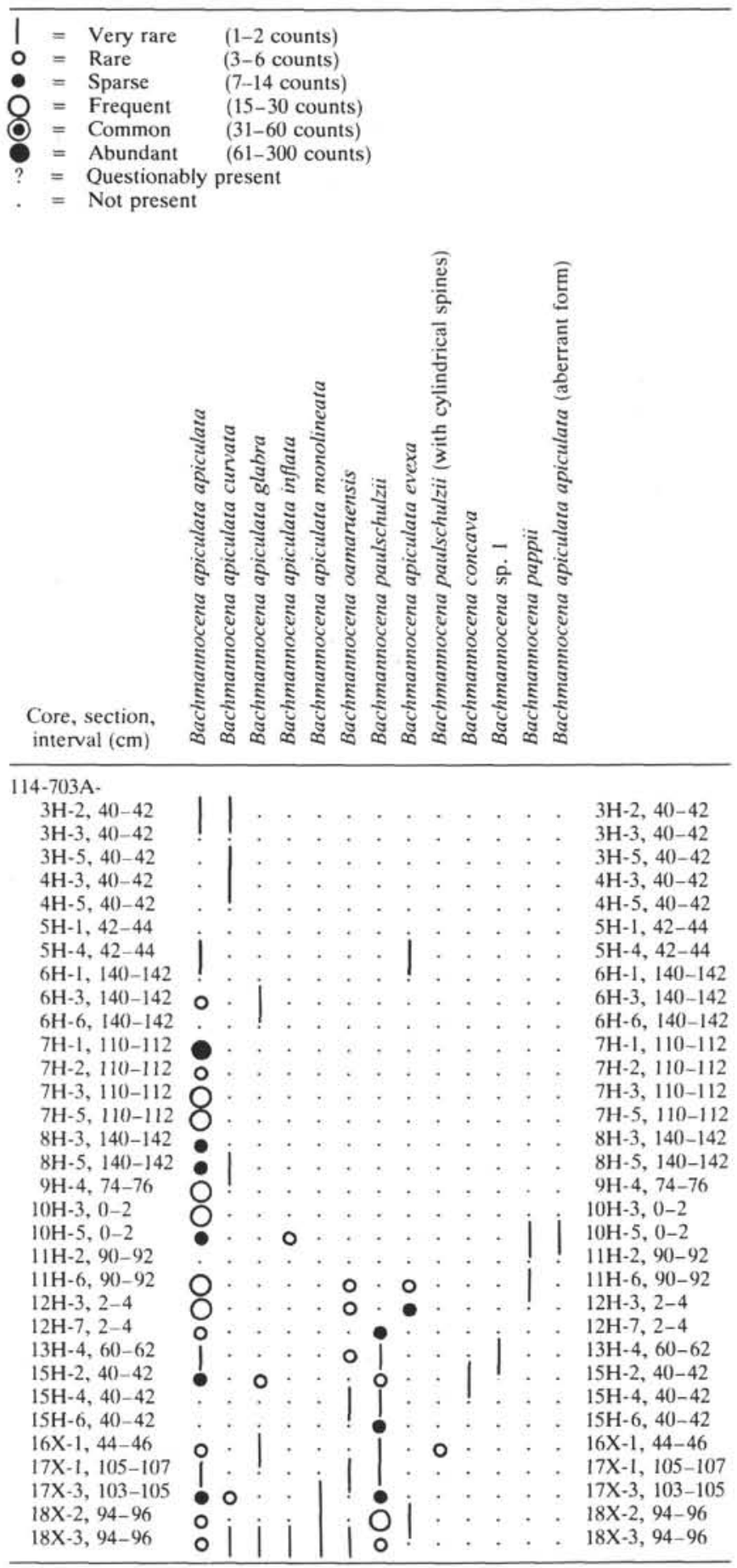

Figure 9. Range chart of graphic abundances of Bachmannocena species from Hole 703A in order of lowest appearance.

FAD Dictyocha aspera martinii $=38.8-39.25 \mathrm{Ma}$ FAD Dictyocha deflandrei completa $=38.8-39.25 \mathrm{Ma}$, first consistent occurrence Naviculopsis trispinosa trispinosa $=38.8-39.25 \mathrm{Ma}$, LAD Corbisema angularis $=38.8-39.25 \mathrm{Ma}$, and FAD $D$. deflandrei completa $=$ 38.8-39.25 Ma.

Remarks. The abundance of $N$. pandalata appears to be highly variable, ranging from $20 \%$ to less than $1 \%$. The low percentage of the species in two of the samples does not inhibit recognition of the zone as it may still be observed quickly in slides because of the great abundance of silicoflagellates in sediments of this age.
Correlation. The upper boundary of the zone is recognized in Holes $702 \mathrm{~B}$ and $703 \mathrm{~A}$, where it occurs in the calcareous nannofossil Chiasmolithus oamaruensis zone. In Hole 703A, the boundary is directly correlated to Subchron C16N, and the combined records of both holes restrict this upper boundary to calcareous nannofossil Zone CP15a and foraminifer Zone P15. Based upon an assumption of a constant sedimentation rate for Subchron $C 16 \mathrm{~N}$, the age of this boundary is $38.65-38.31 \mathrm{Ma}$. Using the age of the lower boundary of the zone with the $D$. grandis Zone (discussed previously), the $N$. pandalata Zone ranges in age from a lower boundary within Subchron 
Table 1. Absolute abundances of silicoflagellates from the Paleogene of Hole 698A in order of their highest appearance.

\begin{tabular}{|c|c|c|c|c|c|c|c|c|c|c|c|c|c|c|c|c|c|c|c|c|c|c|}
\hline $\begin{array}{l}\text { Core, section, } \\
\text { interval }(\mathrm{cm})\end{array}$ & 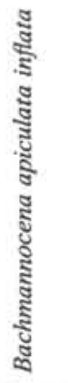 & 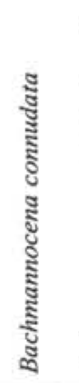 & 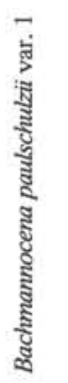 & 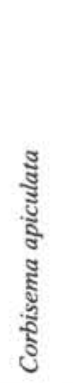 & 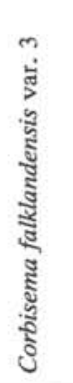 & 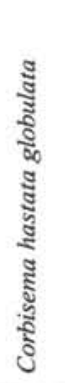 & 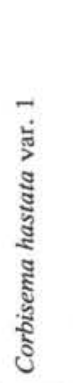 & $\begin{array}{l}\text { मे } \\
\text { के } \\
\text { हूँ } \\
\text { है } \\
\text { ड़े }\end{array}$ & 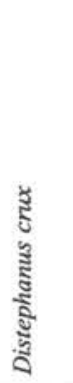 & 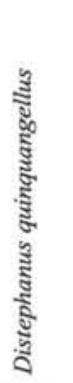 & 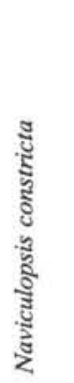 & 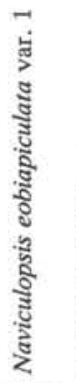 & 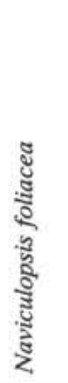 & 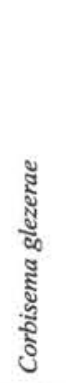 & 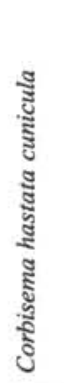 & 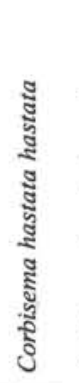 & 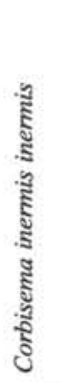 & 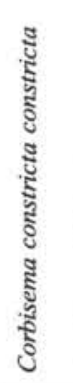 & 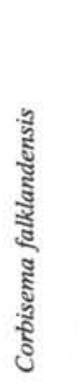 & 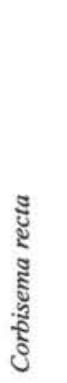 & 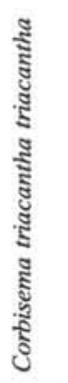 & 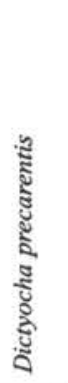 \\
\hline \multicolumn{23}{|l|}{$114-698 \mathrm{~A}$} \\
\hline & & 3 & 5 & $\begin{array}{c}4 \\
\ldots\end{array}$ & 2 & & 1 & 1 & $\begin{array}{r}1 \\
\ldots .\end{array}$ & 2 & $\begin{array}{r}125 \\
4\end{array}$ & $\begin{array}{r}69 \\
1\end{array}$ & 6 & 2 & & & & & & & & \\
\hline $12 \mathrm{R}-1,40-42$ & & & & & & . & & & & & & & & 3 & & 47 & & 2 & 1 & 2 & 1 & \\
\hline
\end{tabular}

C16R to uppermost Subchron C17N ( 39.80-39.24 Ma) to an upper boundary of $38.5 \mathrm{Ma}$.

Interval. The $N$. pandalata Zone is recognized in Holes 702B and $703 \mathrm{~A}$. The base of the zone in Hole 702B occurs between Samples 114-702B-5X-4, $42 \mathrm{~cm}$, and 114-702B-5X-6, $40 \mathrm{~cm}(39.72-42.70 \mathrm{~cm})$, and the upper boundary is placed between Samples 114-702B-4X-4, $60 \mathrm{~cm}$, and 114-702B-4X-2, $62 \mathrm{~cm}(30.40-27.42 \mathrm{mbsf})(\mathrm{P}$. F. Ciesielski, unpubl. data). In Hole $703 \mathrm{~A}$ the base of the zone is located at a disconformity between Samples 114-702B-18X-3, $96 \mathrm{~cm}$, and 114$702 \mathrm{~B}-19 \mathrm{X}-1,0 \mathrm{~cm}$ (156.86-162.40 mbsf), and its upper boundary is between Samples 114-703A-17X-1, $105 \mathrm{~cm}$, and 114-703A-16X-1, 46 cm (144.50-138.36 mbsf).

\section{Naviculopsis constricta-Bachmannocena paulschulzii Zone}

Definition. Interval from the last occurrence of Naviculopsis pandalata to the last abundant appearance datum of Naviculopsis constricta (Ciesielski, herein).

Assemblage. Silicoflagellate abundance and diversity are very high within this zone. The most abundant species is $N$. constricta, as it was in the previous zone. Other species of lesser abundance include Naviculopsis eobiapiculata, Naviculopsis trispinosa trispinosa, Distephanus crux, Dictyocha deflandrei completa, and Bachmannocena paulschulzii.

Datums. FAD Naviculopsis biapiculata biapiculata $=37.4 \mathrm{Ma}$, LAD Dictyocha acuta $=38.2-37.6 \mathrm{Ma}$, LAD Dictyocha quadria $=$ 38.2-37.6 Ma, and only Dictyocha fibula formicata $=38.2 \mathrm{Ma}$.

Remarks. $N$. constricta is extremely abundant in the upper Eocene. It abruptly decreases from more than $30 \%$ of the assemblage to only a small percentage within Subchron C13R and near the Eocene/Oligocene boundary. This abrupt decrease in abundance makes for easy recognition of the top of the zone. Reference to the abundances of $N$. constricta in Leg 71 sections, studied by Shaw and Ciesielski (1983) from the southwest Atlantic sector of the Southern Ocean, reveals that this event was not recovered in the Leg 71 sequences.

Correlation. The base of the zone occurs within Subchron C16N with an estimated age of $38.5 \mathrm{Ma}$. The upper boundary is within Subchron C13R and within calcareous nannofossil Zone CP15b. The last abundant appearance datum (LAAD) of $N$. constricta was noted only $40 \mathrm{~cm}$ above the Subchron C13/C15 boundary (37.24 Ma); however, its true LAAD may be slightly younger as a hiatus has removed a portion of Subchrons C13R and C13N between the samples bracketing the datum. Based upon the age of the truncated biostratigraphic ranges (P. F. Ciesielski, unpubl. data) the disconformity represents $\sim 35.4$ to $36.9 \mathrm{Ma}$. Further evidence regarding the age of this datum comes from partially completed examination of silicoflagellates from Hole $699 \mathrm{~A}$, which reveals that the LAAD of $N$. constricta must be below the LAD Discoaster saipanensis ( $36.7 \mathrm{Ma}$ ) (P. F. Ciesielski, unpubl. data). It appears, therefore, that little or none of the upper range of common $N$. constricta was subject to removal by the disconformity. At present the LAAD of $N$. constricta is estimated to be between 36.9 and $37.2 \mathrm{Ma}$.
Interval. The $N$. constricta-B. paulschulzii Zone is present in Holes $702 \mathrm{~B}$ and $703 \mathrm{~A}$. In Hole $702 \mathrm{~B}$ the lower boundary is placed between Samples 114-702B-4X-4, $60 \mathrm{~cm}$, and 114-702B-4X-2, $62 \mathrm{~cm}$ (30.40-27.42 mbsf), and the upper boundary occurs at a disconformity between Samples 114-702B-3H-6, $42 \mathrm{~cm}$, and 114-702B-3H-5, $82 \mathrm{~cm}$ (23.72-22.62 mbsf). In Hole 703A the lower boundary is between Samples 114-703A-17X-1, $105 \mathrm{~cm}$, and 114-703A-16X-1, $46 \mathrm{~cm}$ (144.50-138.36 mbsf). The upper boundary of the zone in Hole 703A is poorly constrained as a result of poor recovery and sediment disturbance; it occurs between Samples 114-703A-15H-2, $40 \mathrm{~cm}$, and $114-703 \mathrm{~A}-13 \mathrm{H}-4,62 \mathrm{~cm}(130.10-114.52 \mathrm{mbsf})$.

\section{Bachmannocena paulschulzii Zone}

Definition. Interval from the LAAD of Naviculopsis constricta (Ciesielski, herein) to the first abundant appearance datum (FAAD) of Naviculopsis trispinosa (Shaw in Shaw and Ciesielski, 1983).

Assemblage. In the current study the zone is only recognized in a single sample from Hole $703 \mathrm{~A}$ and in Hole $699 \mathrm{~A}$, where quantitative studies of the assemblage are incomplete. The reader is referred, therefore, to Shaw and Ciesielski (1983) for a partial tabulation of the zonal assemblage.

Remarks. Shaw (Shaw and Ciesielski, 1983) established this zone in Hole 513A, but defined only the upper boundary of the zone because of the similarity of assemblages from this boundary to the base of the hole. The older silicoflagellate-bearing sequences of Leg 114 allow definition of the base of the zone as defined previously.

Correlation. The upper boundary is defined in Hole 699A within the calcareous nannofossil Blackities spinosus Zone of Wise (1983) and Reticulofenestra oamaruensis Subzone of the Isthmolithus recurvus Zone of Crux (this volume) and the diatom Melosira architecturalis Zone of Gombos and Ciesielski (1983). The upper boundary is directly correlated to the magnetic polarity record of Hole $699 \mathrm{~A}$ within Subchron C13R. Based upon the position of the upper boundary of the zone between the top of Subchron C13R (35.87 Ma) and the LAD of Discoaster saipanensis $(36.7 \mathrm{Ma})$, the upper zonal boundary is $\sim 36.3 \mathrm{Ma}$. The duration of the zone is limited to Subchron C13R and is approximately 0.6 to $0.9 \mathrm{~m} . \mathrm{y}$.

Interval. The base of the zone in Hole 703A occurs between Samples 114-703A-15H-2, $40 \mathrm{~cm}$, and 114-703A-13H-4, $62 \mathrm{~cm}$ (130.10-114.52 mbsf); the top of the zone occurs between Samples $114-703 \mathrm{~A}-13 \mathrm{H}-4,60 \mathrm{~cm}$, and 114-703A-12H-7, $4 \mathrm{~cm}(114.5-109.40$ mbsf). The upper boundary of the zone at this site is a disconformity, which is missing a portion of Subchrons C13R and C13N. The base of the zone in Hole 699A has not yet been identified; however, the upper boundary occurs between Samples 114-699A-32X-5, $60 \mathrm{~cm}$, and 114-699A-32X-7, $17 \mathrm{~cm}$ (294.20-297.10 mbsf) (P. F. Ciesielski, unpubl. data).

\section{Naviculopsis trispinosa Zone}

Definition. Interval from the FAAD of Naviculopsis trispinosa (Shaw in Shaw and Ciesielski, 1983) to the last occurrence of Naviculopsis trispinosa eminula (Ciesielski, herein). Two subzones 
Table 1 (continued).

\begin{tabular}{|c|c|c|c|c|}
\hline & 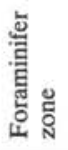 & 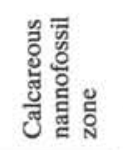 & $\begin{array}{l}\text { Silicoflagellate } \\
\text { zone }\end{array}$ & Age \\
\hline $3 \mathrm{R}-1,40-42$ & P8-9 & NP14-?15 & $\begin{array}{l}\text { Naviculopsis } \\
\text { foliacea }\end{array}$ & $\begin{array}{l}\text { early } \\
\text { Eocene }\end{array}$ \\
\hline $\begin{array}{l}10 \mathrm{R}-2,44-46 \\
12 \mathrm{R}-1,40-42\end{array}$ & P4 & $\begin{array}{c}\text { NP8 } \\
\text { NP5-7 }\end{array}$ & D. precarentis & $\begin{array}{c}\text { late } \\
\text { Paleocene }\end{array}$ \\
\hline
\end{tabular}

are recognized, a lower Subzone a and an upper Subzone b, bound by the last consistent occurrence of Dictyocha deflandrei (Ciesielski, herein).

Assemblage. Dominant components of the assemblage in all or portions of the zone include Dictyocha deflandrei deflandrei, Dictyocha deflandrei completa, Distephanus crux, Naviculopsis trispinosa trispinosa, $N$. trispinosa eminula, Naviculopsis biapiculata biapiculata, Naviculopsis biapiculata nodulifera, Naviculopsis biapiculata var. 1, and Bachmannocena apiculata apiculata.

Datums. LAD $N$. trispinosa trispinosa $=29.5-29.1 \mathrm{Ma}, \mathrm{FAD}$ Dictyocha frenguelli $=29.5-29.9$, FAD Corbisema archangelskiana $=29.9-29.1$, FAD Distephanus crux darwinii $=31.2-31.6 \mathrm{Ma}, \mathrm{FAD}$ Distephanus raupii $=31.2-31.6$, last consistent Dictyocha deflandrei deflandrei $=34.7-32.7$, LAD Corbisema apiculata apiculata $=$ Subchron C12R, LAD Corbisema hastata miranda $=$ Subchron C12R, LAD Bachmannocena oamaruensis $=$ Subchron C12R, LAD Dictyocha aspera martinii $=$ Subchron $\mathrm{C} 12 \mathrm{R}$, LAD Bachmannocena paulschulzii $=$ Subchron $\mathrm{C} 12 \mathrm{R}$, last consistent Naviculopsis constricta $=$ Subchron $\mathrm{C} 12 \mathrm{~N}-\mathrm{C} 11 \mathrm{R}$, and last consistent Dictyocha deflandrei completa $=$ Subchron C11.

Remarks. Shaw (in Shaw and Ciesielski, 1983) defined the top of the zone as the lowest consistent occurrence of Dictyocha deflandrei in Hole 511. The use of this datum to define the top of the zone is rejected here because this species appears to have particular sensitivity to cooler waters, migrating in and out of the subantarctic with changing conditions. The "lowest" occurrence noted by Shaw is no doubt in the upper acme of the species noted within the presently defined zone. Below an interval in Hole 703A where it is absent, another interval of occurrence was noted, which was missed by Shaw as this part of the section was unrecovered by Leg 71. In short, the sporadic occurrence of $D$. deflandrei prevents reliable use of its earliest consistent occurrence as a datum. Its last consistent occurrence is used to define the newly created Subzones a and b. Both $D$. deflandrei deflandrei and $D$. deflandrei completa are common and consistent in the early Oligocene and their abrupt demise appears synchronous in Holes 511, 703A, and 699A.

The top of the zone is redefined as the last occurrence of $N$. trispinosa eminula, which occurs only shortly after the last occurrence of $N$. trispinosa trispinosa. The base of the zone is maintained after Shaw (Shaw and Ciesielski, 1983), the initial abundant appearance datum of $N$. trispinosa, which she defined as being greater than $10 \%$ of the assemblage. This study reveals that the sudden increase in abundance of this species is in part the result of the initial appearance of $N$. trispinosa eminula, which was tabulated with $N$. trispinosa by Shaw. The initial abundance datum is herein defined as the initial contribution of $N$. trispinosa trispinosa and $N$. trispinosa eminula (combined) as greater than $10 \%$ of the assemblage.

Two disconformities occur within the zone of Hole 703A (P. F. Ciesielski, unpubl. data). One occurs within Subzone a (between Samples $114-703 \mathrm{~A}-11 \mathrm{H}-6,90-92 \mathrm{~cm}$, and $114-703 \mathrm{~A}-11 \mathrm{H}-2,90-92$ $\mathrm{cm}$ ), which represents a portion of Subchron C12R. The second hiatus
Table 2. Samples from Hole 698A Paleogene and Cretaceous sequences that are barren of silicoflagellates.

\begin{tabular}{|c|}
\hline $\begin{array}{l}\text { Core, section, } \\
\text { interval }(\mathrm{cm})\end{array}$ \\
\hline $\begin{array}{l}\text { 114-698A- } \\
2 \mathrm{R}-1,40-42 \\
2 \mathrm{R}-2,40-42 \\
2 \mathrm{R}-3,40-42 \\
4 \mathrm{R}-1,40-42 \\
5 \mathrm{R}-1,40-42 \\
5 \mathrm{R}-2,40-42 \\
6 \mathrm{R}-1,42-44 \\
6 \mathrm{R}-2,40-42 \\
8 \mathrm{R}-1,39-41 \\
9 \mathrm{R}-1,42-44 \\
9 \mathrm{R}-2,46-47 \\
10 \mathrm{R}-1,45-47 \\
15 \mathrm{R}-1,38-40 \\
16 \mathrm{R}-1,39-41 \\
16 \mathrm{R}-2,39-41 \\
17 \mathrm{R}-1,41-43 \\
17 \mathrm{R}-2,42-44 \\
20 \mathrm{R}-1,38-40 \\
21 \mathrm{R}-1,32-34\end{array}$ \\
\hline
\end{tabular}

occurs within the unsampled interval between Subzone a and the top of the zone (between Samples 114-703A-10H-3, 0-2 cm, and 114$703 \mathrm{~A}-9 \mathrm{H}-4,74-76 \mathrm{~cm})$, representing a portion of Subchron C9R through upper Subchron C11N.

Correlation. The incomplete representation of the zone in Hole $703 \mathrm{~A}$ prevents recognition of Subzone b. If present in Hole 703A, Subzone $b$ must be present in the unsampled interval between Samples $114-703 \mathrm{~A}-10 \mathrm{H}-3,0 \mathrm{~cm}$, and $114-703 \mathrm{~A}-9 \mathrm{H}-4,76 \mathrm{~cm}$. The paleomagnetic record near the Subzone a/b boundary in Hole 699A is incomplete and preservation is fair to poor (P. F. Ciesielski, unpubl. data); however, it is evident that it occurs within Subchrons C1IR to $\mathrm{C} 12 \mathrm{~N}$ ( 32.06 to $32.90 \mathrm{Ma}$ ). Until more detailed studies of these sections are made, the subzonal boundary can not be more accurately placed than between Subchrons $\mathrm{C} 11 \mathrm{~N}$ and $\mathrm{C} 12 \mathrm{~N}$ with a probable age of 32 to $32.9 \mathrm{Ma}$.

The upper boundary of the zone may be slightly diachronous. In Hole 699A it is noted within Subchron C9N between 29.1 and 28.7 $\mathrm{Ma}$, whereas in Hole $703 \mathrm{~A}$ it occurs in Subchron C9R. Its earlier disappearance in Hole 703A may be a consequence of dissolution in the portion of upper Subchrons C9R and C9N present at this site. The high sedimentation rate and continuous nature of the Hole 699A section and the possible influence of dissolution in Hole 703A favor placement of the upper zonal boundary as defined in Hole 699A. In both sections the upper boundary of the zone occurs within the calcareous nannofossil Chiasmolithus altus Zone and diatom Synedra jouseana Zone.

The base of the zone is defined in Hole 699A within the calcareous nannofossil Blackities spinosus zone of Wise (1983) and Reticulofenestra oamaruensis Subzone of the Isthmolithus recurvus Zone of Crux (this volume) and the diatom Melosira architecturalis Zone of Gombos and Ciesielski (1983). As stated in the discussion of the previous zone, the base occurs in Subchron C13R with an estimated age of $36.3 \mathrm{Ma}$.

The zone includes a portion of the $I$. recurvus Zone, Reticulofenestra daviesii Zone, and a portion of the Chiasmolithus altus Zone as defined by Crux (this volume). It also includes the upper $M$. architecturalis Zone, Brightwellia spiralis Zone, and Rhizosolenia gravida Zone of Gombos and Ciesielski (1983).

Interval. The $N$. trispinosa Zone was recognized in Holes 703A and $699 \mathrm{~A}$. The base of the zone is recognized between Samples $114-703 \mathrm{~A}-13 \mathrm{H}-4,60 \mathrm{~cm}$, and $114-703 \mathrm{~A}-12 \mathrm{H}-7,4 \mathrm{~cm}(114.5-109.40$ mbsf); the upper boundary occurs between Samples 114-703A-9H-4, $74 \mathrm{~cm}$, and $114-703 \mathrm{~A}-8 \mathrm{H}-5,142 \mathrm{~cm}(76.64-69.32 \mathrm{mbsf})$. The boundary between Subzone a and Subzone b, if present, occurs in the unsam- 


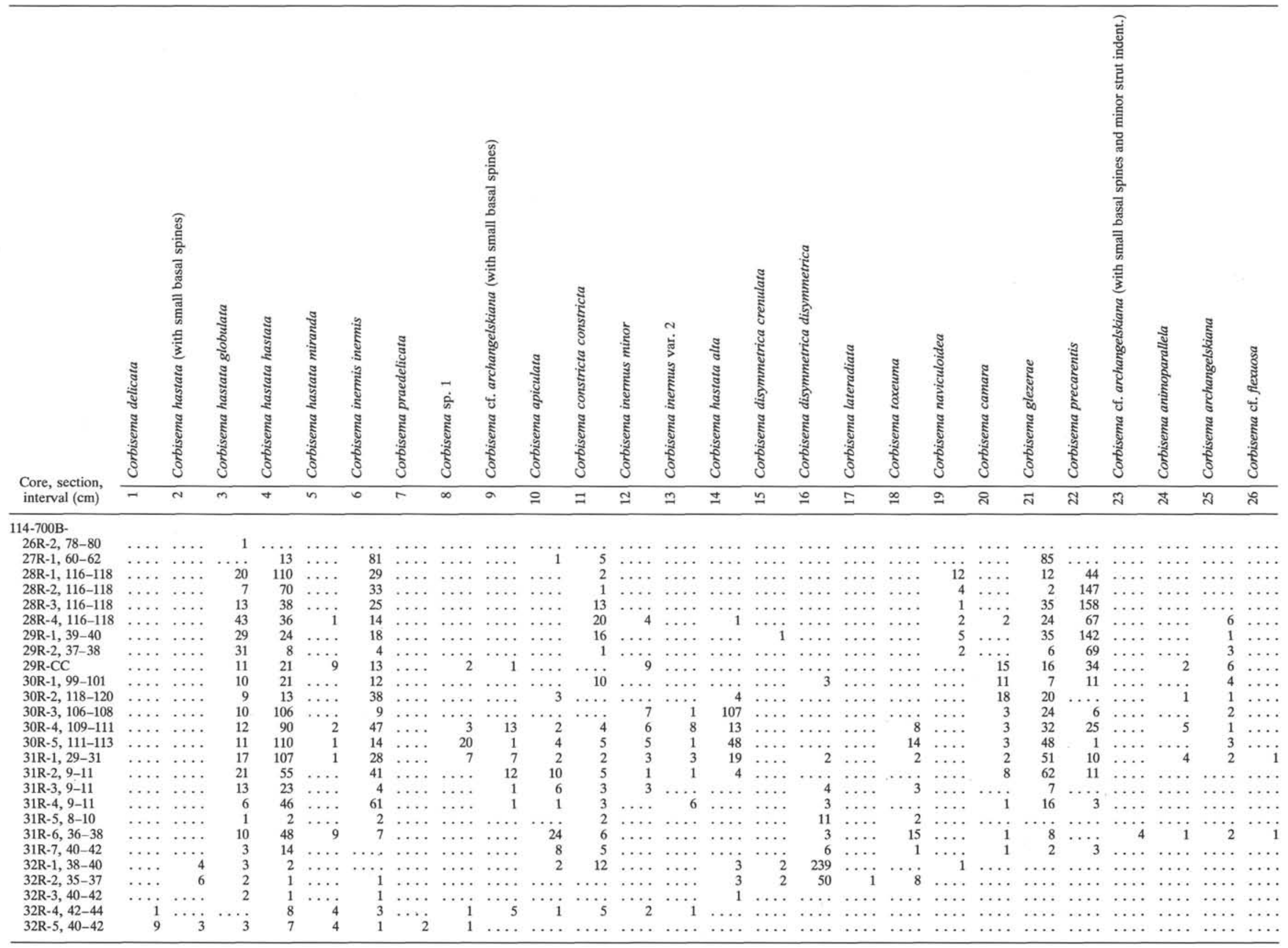



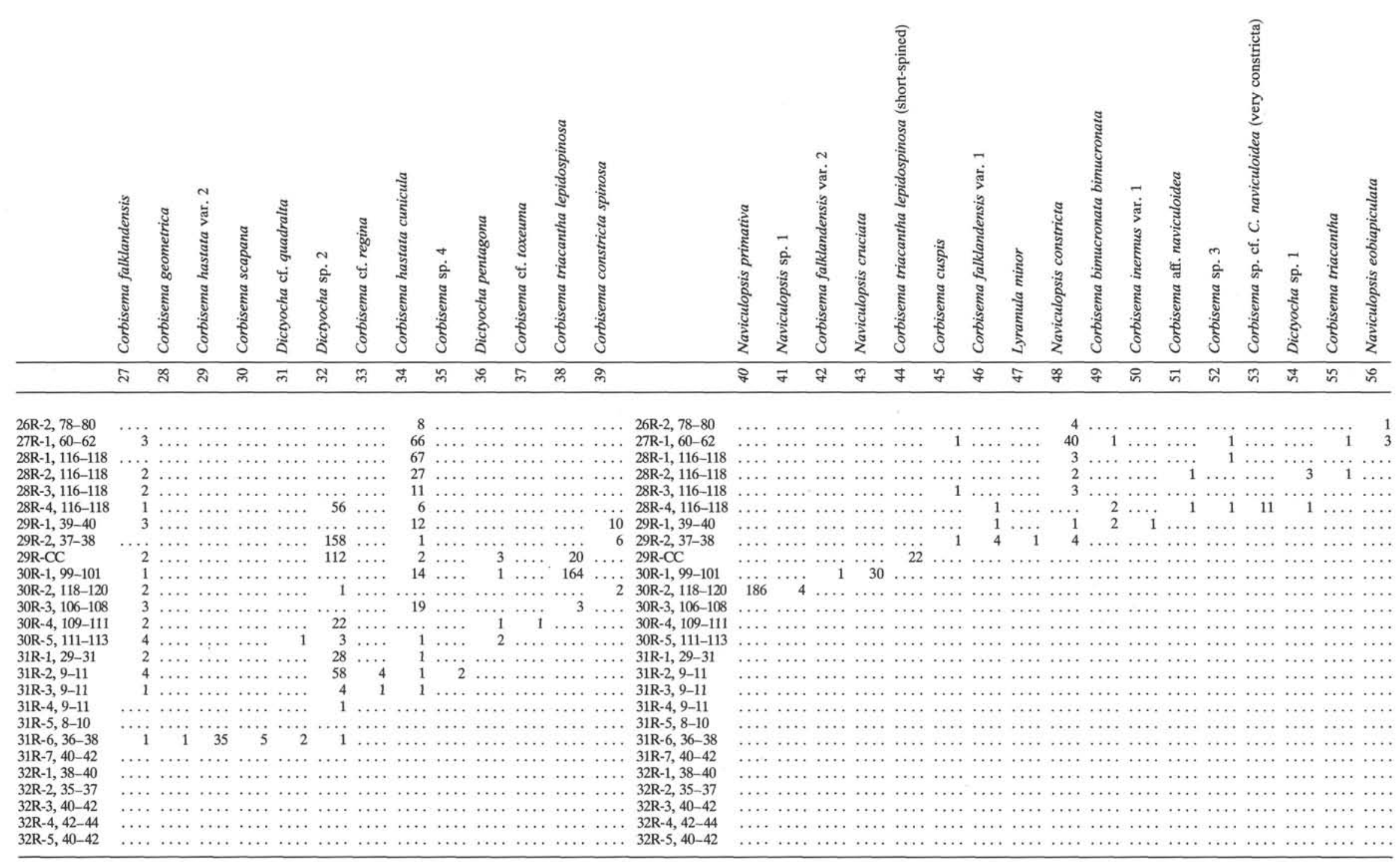
Table 3 (continued).

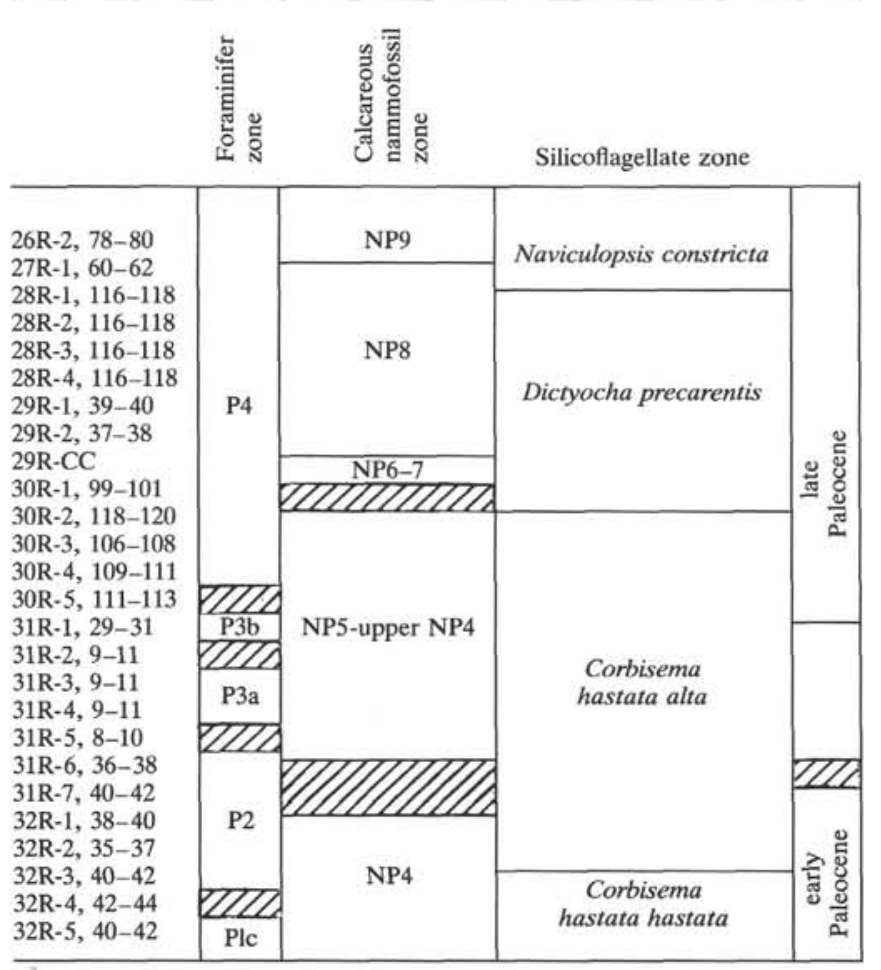

Note: Shading designates range of uncertainty for zonal boundary.
Index number

Species

number

Species

23 C. cf. archangelskiana (with small basal spines and minor strut indent.) 19 Corbisema naviculoided 9 C. cf. archangelskiana (with small basal spines)

Corbisema praedelicat

51 Corbisema aff. naviculoidea

10 Corbisema animoparal

25 Corbisema archangelskiane

49 Corbisema bimucronata bimucronata

20 Corbisema camara

26 Corbisema cf. flexuosa

33 Corbisema cf. regina

37 Corbisema cf. toxeuma

11 Corbisema constricta constricta

39 Corbisema constricta spinosa

45 Corbisema cuspis

1 Corbisema delicata

16 Corbisema disymmetrica disymmetrica

Corbisema falklandensis

46 Corbisema falklandensis var.

42 Corbisema falklandensis var.

28 Corbisema geometrica

21 Corbisema glezerae

2 Corbisema hastata (with small basal spines)

14 Corbisema hastata alta

34 Corbisema hastata cunicula

3 Corbisema hastata globulata

4 Corbisema hastata hastata

5 Corbisema hastata miranda

29 Corbisema hastata var. 2

6 Corbisema inermis inermis

12 Corbisema inermus minor

50 Corbisema inermus var. 1

13 Corbisema inermus var.

22 Dictyocha precarentis
30 Corbisema scapana

8 Corbisema sp. 1

52 Corbisema sp. 3

53 Corbisema sp. cf. C. naviculoidea (very constricta)

18 Corbisema toxeuma

55 Corbisema triacantha

38 Corbisema triacantha lepidospinosa

44 Corbisema triacantha lepidospinosa (short-spined)

31 Dictyocha cf. quadralta

36 Dictyocha pentagona

54 Dictyocha sp. 1

32 Dictyocha sp. 2

47 Lyramula minor

48 Naviculopsis constricta

43 Naviculopsis cruciata

56 Naviculopsis eobiapiculata

40 Naviculopsis primativ

41 Naviculopsis sp. 1 
Table 4. Samples from Hole 700B Paleogene and Cretaceous sequences that are barren of silicoflagellates.

\begin{tabular}{|c|}
\hline $\begin{array}{l}\text { Core, section, } \\
\text { interval }(\mathrm{cm})\end{array}$ \\
\hline $\begin{array}{l}\text { 114-700B- } \\
3 \mathrm{R}-1,130-132 \\
4 \mathrm{R}-1,120-122 \\
5 \mathrm{R}-1,120-122 \\
6 \mathrm{R}-2,135-137 \\
6 \mathrm{R}-4,135-137 \\
7 \mathrm{R}-2,50-52 \\
7 \mathrm{R}-5,50-52 \\
8 \mathrm{R}-5,85-87 \\
9 \mathrm{R}-5,90-92 \\
10 \mathrm{R}-3,38-40 \\
13 \mathrm{R}-1,60-62 \\
13 \mathrm{R}-5,60-62 \\
16 \mathrm{R}-1,21-23 \\
16 \mathrm{R}-4,20-22 \\
16 \mathrm{R}-6,20-22 \\
18 \mathrm{R}-1,50-52 \\
18 \mathrm{R}-4,26-28 \\
20 \mathrm{R}-3,44-46 \\
21 \mathrm{R}-3,39-41 \\
26 \mathrm{R}-1,120-122 \\
33 \mathrm{R}-1,44-46 \\
34 \mathrm{R}-1,59-61 \\
35 \mathrm{R}-1,44-46 \\
36 \mathrm{R}-1,25-27 \\
37 \mathrm{R}-1,79-81 \\
38 \mathrm{R}-1,75-77 \\
38 \mathrm{R}-5,75-77 \\
39 \mathrm{R}-4,46-48 \\
40 \mathrm{R}-3,41-43 \\
41 \mathrm{R}-3,131-133\end{array}$ \\
\hline
\end{tabular}

pled interval between Samples 114-703A-10H-3, $0 \mathrm{~cm}$, and 114-703A$9 \mathrm{H}-4,76 \mathrm{~cm}(83.90-76.66 \mathrm{mbsf})$.

A very complete and expanded section of the zone occurs in Hole 699A (P. F. Ciesielski, unpubl. data). The base of the zone occurs between Samples 114-699A-32X-5, $60 \mathrm{~cm}$, and 114-699A-32X-7, 17 $\mathrm{cm}(294.20-297.10 \mathrm{mbsf})$, and the upper boundary is between Samples $114-699 \mathrm{~A}-20 \mathrm{H}-2,42 \mathrm{~cm}$, and $114-699 \mathrm{~A}-19 \mathrm{H}-4,42 \mathrm{~cm}(181.50-175.02$ mbsf). The boundary between Subzones a and b occurs between Samples 114-699A-27X-5, $124 \mathrm{~cm}$, and 114-699A-24H-7, $11 \mathrm{~cm}$ (250.34-224.10 mbsf)

\section{Corbisema archangelskiana Zone}

Definition. Interval from the last appearance of Naviculopsis trispinosa eminula (Ciesielski, herein) to the last occurrence of Corbisema archangelskiana (Ciesielski, 1983).

Assemblage. A full accounting of the assemblage of the zone awaits further study of Hole 699A; however, studied assemblages from Holes 703A and 513A (Shaw and Ciesielski, 1983) reveal the most frequent elements to be $C$. archangelskiana, Distephanus raupii, Distephanus speculum, Distephanus boliviensis (hemisphaericoid), Distephanus crux, Naviculopsis eobiapiculata, Naviculopsis biapiculata, and Bachmannocena apiculata apiculata.

Datums. LAD Naviculopsis biapiculata nodulifera $=$ Subchron $\mathrm{C} 8 \mathrm{~N}-\mathrm{C} 7 \mathrm{R}$ and last consistent and common $B$. apiculata apiculata $=$ Subchron $\mathrm{C} 7 \mathrm{~N}$.

Remarks. Ciesielski (1983) defined the zone by the total Oligocene range of $C$. archangelskiana. This species occurs sporadically throughout the Paleocene-Oligocene, although its occurrence within the Oligocene is restricted almost entirely the upper Oligocene, where it is typically common.

Ciesielski defined the base of the zone in Hole 513A; however, its relationship to the lower/upper Oligocene boundary was not well defined due to a dissolution zone between its base and the lower Oligocene. In Hole 699A, silicoflagellate assemblages are better preserved near the lower/upper Oligocene boundary, where there also is a good quality paleomagnetic record. In Hole 699A, the FAD of $C$. archangelskiana (29.9-29.5 Ma) occurs nearly concurrently with the LAD of Naviculopsis trispinosa trispinosa (29.5-29.1 Ma) and prior to the LAD of $N$. trispinosa eminula (29.1-28.7 Ma). The better preservation of this part of the Oligocene in Hole 699A reveals that the FAD of $C$. archangelskiana within the Oligocene does occur within the upper Oligocene as previously thought, in the lower upper Oligocene within Subchron C10N to upper Subchron C9R. The LAD of $N$. trispinosa eminula is slightly younger, occurring within lower Subchron C9N. Either the beginning of the Oligocene range of $C$. archangelskiana or the LAD of $N$. trispinosa eminula would serve equally well for the zonal boundary as they are not greatly different in age. The zone is revised to have its base defined by the last $N$. trispinosa eminula because $C$. archangelskiana is generally rare in the early portion of its range.

As a result of the occurrence of disconformities, only a portion of the zone is recognized in Hole 703A. The most complete representation of the zone to date is in Hole 699A, where quantitative analyses of the assemblage are incomplete.

Correlation. The base of the zone in Hole $699 \mathrm{~A}$ was noted within Subchron C9N between 28.7 and $29.1 \mathrm{Ma}$. The top of the zone is also directly tied to the paleomagnetic record in this hole, occurring between the top of the lower normal of Subchron C6CN (24.04 Ma) to just below the Subchron C6CN/C6CR boundary (24.21 Ma) at approximately $24.3 \mathrm{Ma}$. An intermediate age of $24.2 \mathrm{Ma}$ is given to this upper boundary, closely approximating the Oligocene/Miocene boundary. The age range of the zone is $\sim 28.7-29.1$ to $24.2 \mathrm{Ma}$.

The zone encompasses the upper Chiasmolithus altus Zone, Reticulofenestra bisecta Zone, and lowermost Cyclicargolithus abisectus Zone.

Interval. The $C$. archangelskiana Zone appears in Holes 703A and 699A. The basal boundary occurs between Samples 114-703A-9H-4, $74 \mathrm{~cm}$, and $114-703 \mathrm{~A}-8 \mathrm{H}-5,142 \mathrm{~cm}(76.64-69.32 \mathrm{mbsf})$, and the zonal top occurs at a hiatus between Samples 114-703A-6H-6, $140 \mathrm{~cm}$, and $114-703 \mathrm{~A}-6 \mathrm{H}-3,142 \mathrm{~cm}(51.80-47.32 \mathrm{mbsf})$. Another hiatus occurs within the zone between Samples 114-703A-8H-3, $140 \mathrm{~cm}$, and 114-703A-7H-5, $112 \mathrm{~cm}$, which represents most of Chron C9 and a portion of Chron $\mathrm{C} 8$.

In Hole $699 \mathrm{~A}$ the basal boundary occurs between Samples 114$699 \mathrm{~A}-20 \mathrm{H}-2,42 \mathrm{~cm}$, and 114-699A-19H-4, $42 \mathrm{~cm}$ (181.50-175.02 mbsf); the upper boundary occurs between Samples 114-699A-11H-2, $39 \mathrm{~cm}$, and 114-699A-10H-6, $38 \mathrm{~cm}$ (95.99-92.48 mbsf).

Naviculopsis biapiculata Zone

Definition. Interval from the last occurrence of Corbisema archangelskiana (Ciesielski, 1983) to the last occurrence of Naviculopsis biapiculata (Bukry, 1975a).

Assemblage. The most abundant elements of the zonal assemblage include Distephanus crux darwnii, Distephanus speculum, Distephanus stradneri, and Naviculopsis biapiculata biapiculata.

Remarks. High sediment-accumulation rates prevail at many sites during the interval represented by this brief zone, allowing its easy identification in Holes 513A, 699A, and 703A.

Correlation. The lower boundary is assigned an age of $24.20 \mathrm{Ma}$, between the top of the lower normal of Subchron C6CN (24.04 Ma) to just below the Subchron C6CN/C6CR boundary (24.21 Ma). In Hole $703 \mathrm{~A}$, the LAD N. biapiculata biapiculata occurs in Subchron C6CN with bracketing ages for the datum of 24.0 to $23.5 \mathrm{Ma}$. A disconformity in Hole $699 \mathrm{~A}$, between Subchron C6N and younger Neogene sediments, has removed the uppermost portion of the zone.

The zone is inclusive of a portion of the Chiasmolithus abisectus Zone; however, its relationship with the Reticulofenestra bisecta Zone is ambiguous because of possible diachroneity in the upper boundary of the zone.

Interval. The base of the $N$. biapiculata Zone between Samples $114-703 \mathrm{~A}-6 \mathrm{H}-6,140 \mathrm{~cm}$, and $114-703 \mathrm{~A}-6 \mathrm{H}-3,142 \mathrm{~cm}(51.80-47.32$ mbsf) is unconformable with the $C$. archangelskiana Zone. The top of the zone occurs between Samples 114-703A-6H-1, $140 \mathrm{~cm}$, and 114-703A-5H-4, $44 \mathrm{~cm}(44.30-38.34 \mathrm{mbsf})$, where it is conformable with the Distephanus raupii Zone. In Hole 699A the base of the zone occurs between Samples 114-699A-11H-2, $39 \mathrm{~cm}$, and 114-699A-10H$6,38 \mathrm{~cm}(95.99-92.48 \mathrm{~cm})$, whereas the upper boundary of the zone is truncated by a disconformity located in Core 114-699A-8H between 69.2 and 67.5 mbsf. 


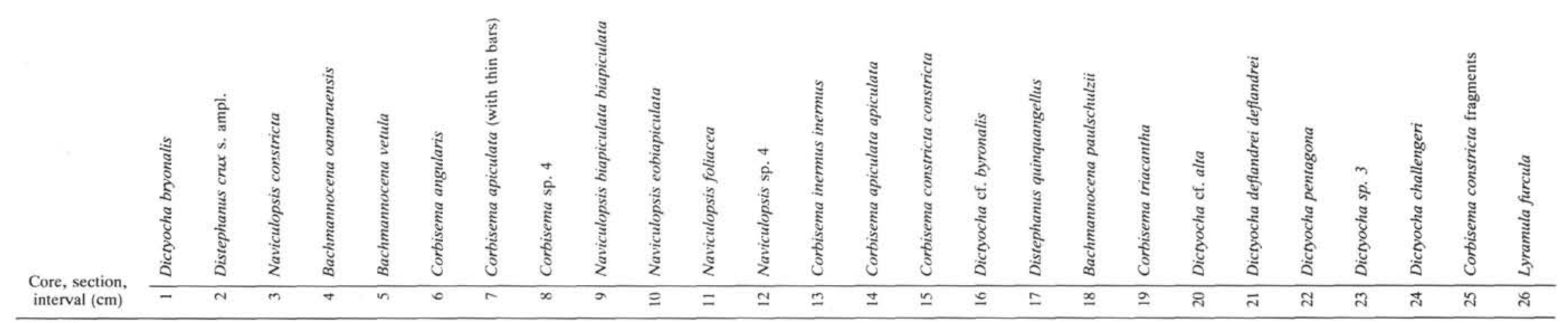

114-702B-

$8 \mathrm{X}-3,40-42$
$8 \mathrm{X}-5,40-42$

9X-1, 118-120

9X-3, 118-120

$9 \mathrm{X}-5,118-120$

$10 \mathrm{X}-3,140-142$

10X-5, 140-14

$11 \mathrm{X}-1,140-142$
$11 \mathrm{X}-3,140-142$

$12 \mathrm{X}-1,130-132$

$12 X-3,130-132$
$12 X-5,119-121$

$13 \mathrm{X}-1,130-132$

$13 X-3,130-132$
$14 X-2,43-45$

$14 X-2,43-45$
$14 X-4,43-45$

$14 X-4,43-45$
$16 X-4,140-142$

$16 \mathrm{X}-6,140-142$

$17 \mathrm{X}-2,4-6$

$18 \mathrm{X}-2,40-42$

\begin{tabular}{|c|c|}
\hline $\begin{array}{l}\text { Index } \\
\text { number }\end{array}$ & Species \\
\hline & Bachmannocena oamaruensis \\
\hline 18 & $\begin{array}{l}\text { Bachmannocena paulschulzii } \\
\text { Bachmannocena vetula }\end{array}$ \\
\hline 27 & Corbisema cf. archangelskiana (with small basal spines) \\
\hline 6 & Corbisema angularis \\
\hline 14 & $\begin{array}{l}\text { Corbisema apiculata apiculata } \\
\text { Cars) }\end{array}$ \\
\hline 15 & Corbisema constricta constricta \\
\hline 25 & Corbisema constricta fragments \\
\hline $\begin{array}{l}36 \\
13\end{array}$ & $\begin{array}{l}\text { Corbisema hastata cuntcula } \\
\text { Corbisema inermus inermus }\end{array}$ \\
\hline 8 & Corbisema sp. 4 \\
\hline 198 & $\begin{array}{l}\text { Corbisema triacantha } \\
D \text { stelliformis and } D \text { grandis fragments }\end{array}$ \\
\hline
\end{tabular}

\begin{tabular}{ll} 
Index & \multicolumn{1}{c}{ Species } \\
number & Dictyocha aff. quadria \\
41 & Dictyocha bryonalis \\
20 & Dictyocha cf. alta \\
16 & Dictyocha cf. byronalis \\
24 & Dictyocha challengeri \\
21 & Dictyocha deflandrei deflandrei \\
29 & Dictyocha grandis \\
37 & Dictyocha grandis (pentagonal basal ring) \\
42 & Dictyocha grandis (with two apical windows) \\
33 & Dictyocha grandis fragments \\
22 & Dictyocha pentagona \\
23 & Dictyocha sp. 3 \\
30 & Dictyocha stelliformis \\
32 & Dictyocha stelliformis (pentagonal basal ring)
\end{tabular}

Index
number

$$
\begin{aligned}
& \text { Species } \\
& 31 \text { Dictyocha stelliformis fragments } \\
& 17 \text { Distephanus crux s. ampl. } \\
& 26 \text { Lyramula furcula } \\
& \text { Naviculopsis biapiculata biapiculata } \\
& \text { Naviculopsis cf. constricta } \\
& \text { Naviculopsis constricta } \\
& \text { Naviculopsis eobiapicular } \\
& \text { Naviculopsis follacea } \\
& \text { Naviculopsis pandalata } \\
& \text { Naviculopsis sp. } 4 \\
& \text { Naviculopsis sp. aff. } N \text {. nordica hyalina }
\end{aligned}
$$


Table 5 (continued).

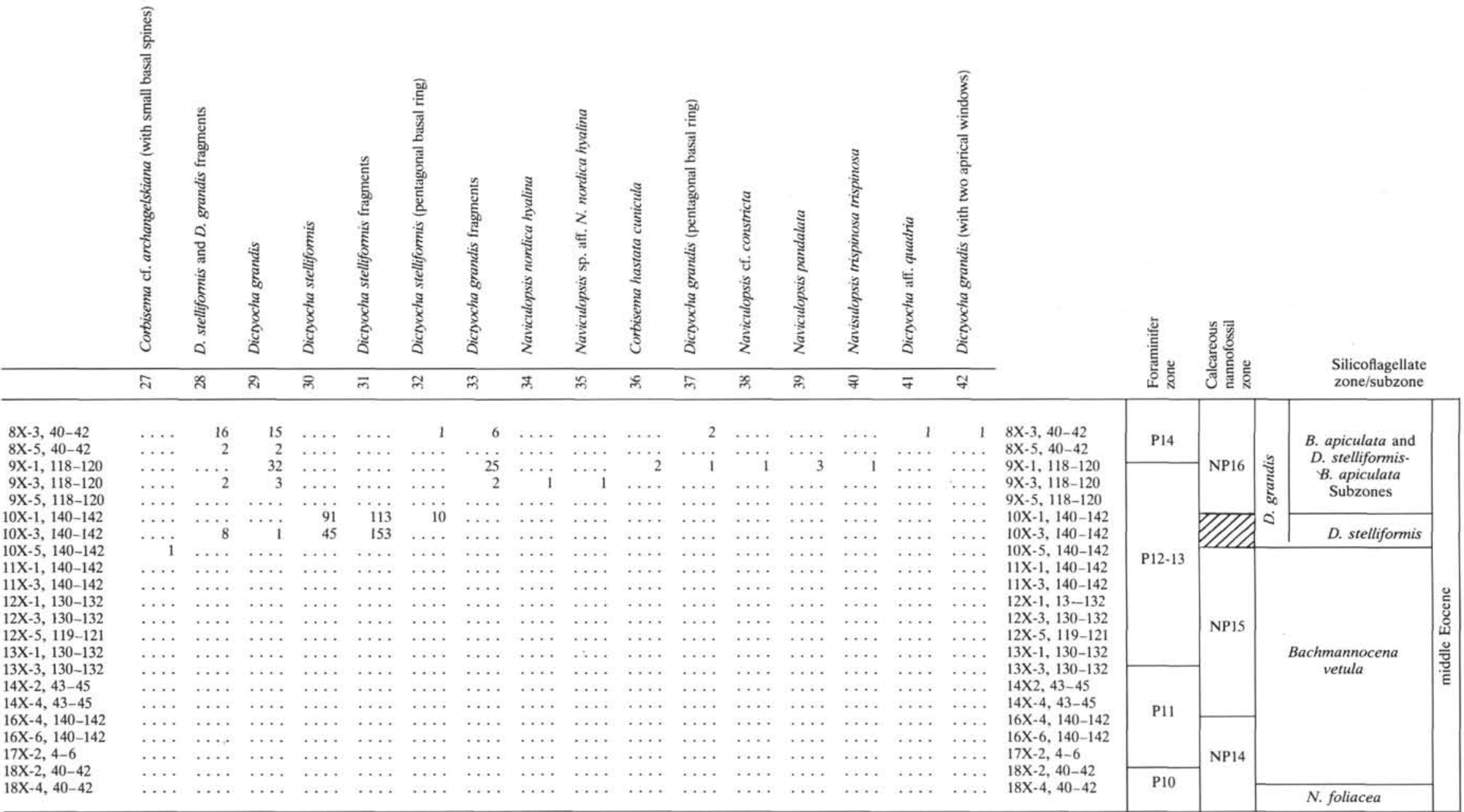

Note: Shading designates range of uncertainty for zonal boundary. 
Table 6. Samples from Hole 702B Paleogene sequences that are barren of silicoflagellates.

\begin{tabular}{l}
\hline $\begin{array}{c}\text { Core, section, } \\
\text { interval (cm) }\end{array}$ \\
\hline $114-702 \mathrm{~B}-$ \\
$11 \mathrm{X}-5,140-142$ \\
$13 \mathrm{X}-5,130-132$ \\
$14 \mathrm{X}-6,43-35$ \\
$15 \mathrm{X}-2,50-52$ \\
$15 \mathrm{X}-4,50-52$ \\
$15 \mathrm{X}-6,50-52$ \\
$17 \mathrm{X}-4,3-5$ \\
$17 \mathrm{X}-6,4-6$ \\
$18 \mathrm{X}-1,40-42$ \\
$19 \mathrm{X}-2,40-42$ \\
$19 \mathrm{X}-4,40-42$ \\
$19 \mathrm{X}-6,40-42$ \\
$20 \mathrm{X}-2,40-42$ \\
$20 \mathrm{X}-4,40-42$ \\
$20 \mathrm{X}-6,40-42$ \\
$21 \mathrm{X}-3,129-131$ \\
$22 \mathrm{X}-1,130-132$ \\
$22 \mathrm{X}-3,130-132$ \\
$23 \mathrm{X}-1,44-46$ \\
$24 \mathrm{X}-3,15-17$ \\
$25 \mathrm{X}-1,48-50$ \\
$26 \mathrm{X}-1,100-102$ \\
$27 \mathrm{X}-1,97-99$ \\
$30 \mathrm{X}-1,44-46$ \\
$30 \mathrm{X}-2,44-46$ \\
$31 \mathrm{X}-1,61-63$ \\
\hline
\end{tabular}

Distephanus raupii Zone

Definition. Interval from the last occurrence of Naviculopsis biapiculata to the last appearance of Distephanus raupii (Ciesielski, herein).

Assemblage. Distephanus raupii and Distephanus crux darwinii account for more than $50 \%$ of the assemblage of the portion of the zone examined. The acme of $D$. crux darwinii, which began in the $N$. biapiculata Zone, ends in the $D$. raupii Zone. $D$. raupii has its greatest abundance at its last occurrence, where it accounts for $63 \%$ of the assemblage. Among the other constituents of the zone are Distephanus crux, Distephanus speculum hemisphaericus, Distephanus speculum, Distephanus stradneri, and Naviculopsis lata.

Datums. FAD Distephanus crux parvus $=23.3-23.5 \mathrm{Ma}, \mathrm{FAD}$ Distephanus crux scutulatus $=23.3-23.5 \mathrm{Ma}$, LAD D. stradneri $=$ 23.5-23.3 Ma, and FAD N. lata $=23.5-24.0 \mathrm{Ma}$.

Remarks. This brief zone ( $23.7-23.1 \mathrm{Ma})$ may only be recognized in locations with a high accumulation rate. It offers added stratigraphic resolution for a period of rapid environmental change for which calcareous microfossils offer little, if any, stratigraphic data in the Southern Ocean.

Correlation. The base of the zone is in Subchron C6CN close to the upper boundary of the mid-normal (23.55 Ma). The upper boundary of the zone is directly correlated to the paleomagnetic record of Hole $703 \mathrm{~A}$, where samples bracketing the datum occur in uppermost Subchrons C6CN (23.3 Ma) and C6BN (22.9 Ma). Using the mean ages of samples bracketing the upper and lower boundaries of the zone, the age range of the zone is from 23.7 to $23.1 \mathrm{Ma}$.

Interval. The $D$. raupii Zone and the subsequent Miocene are absent in Hole 699A. The zone is present in Hole 703A, where its lower boundary occurs between Samples 114-703A-6H-1, $140 \mathrm{~cm}$, and $114-703 \mathrm{~A}-5 \mathrm{H}-4,44 \mathrm{~cm}(44.30-38.34 \mathrm{mbsf})$. The upper boundary occurs between Samples 114-703A-5H-1, $42 \mathrm{~cm}$, and 114-703A-4H-5, $42 \mathrm{~cm}(33.82-30.32 \mathrm{mbsf})$.

\section{Distephanus raupii-Corbisema triacantha Zone}

Definition. Interval from the last occurrence of Distephanus raupii to the initial common occurrence of Corbisema triacantha (Ciesielski, herein).
Assemblage. Very low diversity and poor preservation characterize this zone. Present are very rare to sparse occurrences of Distephanus speculum, D. raupii, Distephanus crux scutulatus, Naviculopsis navicula, Naviculopsis ponticula spinosa, and C. triacantha.

Datums. FAD N. ponticula spinosa $=22.85 \mathrm{Ma}$.

Remarks. The Distephanus raupii-Corbisema triacantha Zone is an interval zone with very poorly preserved silicoflagellates.

Correlation. The lower boundary of the zone is within the upper normal of Subchron C6CN to lowermost Subchron C6BN, with an estimated age of 22.9-23.3 Ma. The upper boundary is not well constrained with respect to the paleomagnetic record of Hole 703A, but occurs between a position in mid-Subchron C6BN $(22.8 \mathrm{Ma})$ and the base of Subchron C6AAN (22.3 Ma).

Interval. The lower boundary of the zone occurs between Samples $114-703 \mathrm{~A}-5 \mathrm{H}-1,42 \mathrm{~cm}$, and $114-703 \mathrm{~A}-4 \mathrm{H}-5,42 \mathrm{~cm}(33.82-30.32$ mbsf). The upper boundary is located between Samples 114-703A$4 \mathrm{H}-3,40 \mathrm{~cm}$, and $114-703 \mathrm{~A}-3 \mathrm{H}-5,42 \mathrm{~cm}(27.3-20.82 \mathrm{mbsf})$.

\section{Corbisema triacantha mediana Zone}

Definition. Interval from the initial common occurrence of Corbisema triacantha to a yet to be specified level (Ciesielski, herein).

Assemblage. Corbisema triacantha accounts for $77 \%-31 \%$ of the assemblage in the portion of the zone recognized in Hole 703A. Corbisema triacantha mediana is rare in the basal sample of the zone but reaches $11 \%$ beneath the overlying disconformity. Other species present include Distephanus speculum, Distephanus speculum hemisphaericus, Distephanus crux, Distephanus cf. boliviensis, and Distephanus speculum var. 1.

Datums. First consistent Distephanus speculum patulus.

Remarks. The base of the zone is easily recognized by the abrupt appearance of $C$. triacantha, which is generally rare and sporadic in occurrence prior to the base of the zone.

Correlation. The base of the zone occurs between a position in mid-Subchron C6BN (22.8 Ma) and the base of Subchron C6AAN $(22.3 \mathrm{Ma})$. The top of the zone is undefined as a result of truncation of the section by a disconformity; however, its minimum age is in or younger than Subchron C6AAN.

Interval. The base of the zone occurs between Samples 114-703A$4 \mathrm{H}-3,40 \mathrm{~cm}$, and $114-703 \mathrm{~A}-3 \mathrm{H}-5,42 \mathrm{~cm}(27.3-20.82 \mathrm{mbsf})$. The top of the zone is undefined because a hiatus truncated the sequence between 18.95 and 17.82 mbsf.

\section{Naviculopsis ponticula Zone}

Definition. Interval from the last occurrence of Naviculopsis quadrata to the last occurrence of the genus Naviculopsis (Bukry, 1981; P. F. Ciesielski, unpubl. data).

Assemblage. The assemblage of the single sample representing this zone is dominated by Corbisema triacantha, Corbisema triacantha mediana, Distephanus speculum patulus, Distephanus speculum, Naviculopsis ponticula spinosa, and Naviculopsis sp. 3 .

Remarks. A hiatus separates sediments between the $C$. triacantha mediana Zone and the $N$. ponticula Zone. Further evaluation of the silicoflagellate biostratigraphy of this interval awaits the examination of age-equivalent sediments present in Hole 704B.

Correlation. The portion of the zone represented here occurs within foraminifer Zone N6. The sample also contains the diatoms Coscinodiscus rhombicus, Nitzschia maleinterpretaria, and Denticulopsis nicobarica (P. F. Ciesielski, unpubl. data), restricting the sample in age to approximately $17.8 \mathrm{Ma}$, with the last Naviculopsis at $17.5 \mathrm{Ma}$.

Interval. Only Sample 114-703A-3H-2, $40-42 \mathrm{~cm}$, represents this zone in Hole 703A, occurring between a hiatus at $18.95 \mathrm{mbsf}$ and another hiatus at 15.95-14.4 mbsf.

\section{TAXONOMY}

Genus BACHMANNOCENA (Locker, 1974) Bukry, 1987 Bachmannocena apiculata apiculata (Schulz, 1928) Bukry, 1987 (PI. 8, Fig. 15)

Remarks. This species is a consistent member of the late Eocene-Oligocene assemblage of Hole $703 \mathrm{~A}$, but is absent from sediments older than middle Eocene. The last consistent and common occurrence of this species in Hole 703A is at a hiatus separating Subchrons C7N and C6CR. An apparently aberrant form 
of the species shown in PI. 8, Fig. 15, has a nodular appearance to the ring.

Bachmannocena apiculata curvata (Bukry, 1976b) Bukry, 1987

Remarks. The amount of indentation of the shorter side is highly variable. B. apiculata curvata is only present sporadically within Hole $703 \mathrm{~A}$.

Bachmannocena apiculata evexa (Bukry, 1985) Bukry, 1987

Remarks. Sporadic specimens are present in Hole 703A.

Bachmannocena apiculata glabra (Schulz, 1928) Bukry, 1978a, 1987 703A.

Remarks. A single specimen of this subspecies was noted in Hole

Bachmannocena apiculata inflata (Bukry, 1978c) Bukry, 1987 (PI. 8, Fig. 13)

Remarks. Sporadic occurrences of the species were noted within the upper Paleocene of Hole 698A and the lower Oligocene of Hole 703A.

\section{Bachmannocena apiculata monolineata Bukry, 1987}

Remarks. Rare occurrences of the species were noted within foraminifer Zone P15 and calcareous nannofossil Zone NP18 of the upper Eocene of Hole 703A. Previous description is from the uppermost Eocene of Site 612 in the northwestern Atlantic Ocean (Bukry, 1987).

Bachmannocena concava (Perch-Nielsen, 1976b) Bukry, 1987

Remarks. Specimens with strongly concave sides were noted only from a single sample of the upper Eocene of Hole 703A, within an interval assigned to foraminifer Zones P17-16.

Bachmannocena connudata (Bukry, 1978c) Bukry, 1987 (Pl. 8, Fig. 7)

Remarks. Three specimens of this rarely noted species were found in the lower Eocene (foraminifer zonal interval P8-9) of Hole 698A. The type occurrence of the species is from the upper Paleocene of Site 384 in the northwestern Atlantic Ocean (Bukry, 1978c).

\section{Bachmannocena oamaruensis (Schulz, 1928) Bukry, 1987}

$$
\text { (PI. 8, Fig. 10) }
$$

Remarks. This species is a relatively minor component of the studied sections. Its first occurrence is within foraminiferal Zones P12-13 in Hole 702B, and its last occurrence was truncated by a hiatus in upper Subchron C12N or near the Subchron C12N/C12R boundary of Hole 703A. Some specimens within the middle Eocene of Hole 702B have slightly indented sides (PI. 8, Fig. 10) but range concurrently with straight-sided forms and do not have the strong indentation of Bachmannocena concava.

\section{Bachmannocena pappii Bachmann, 1962}

\section{(Pl. 8, Fig. 8)}

Remarks. Most occurrences of this species are from the Miocene, whereas the two specimens noted here are from the lower Oligocene of Hole 703A. The paired spines characteristic of this species are probably polyphyletic, arising from several triangular Bachmannocena.

\section{Bachmannocena paulschulzii Bukry, 1987}

Remarks. This species was found in Holes 702B and 703A, ranging from the upper middle Eocene to lower Oligocene. Its first occurrence in the poorly preserved middle Eocene is within lower foraminifer Zones P12-13 and in the calcareous nannofossil Nannotetrina fulgens Zone (NP15-16). The last occurrence of the species in Hole 699A (P. F. Ciesielski, unpubl. data) is not well constrained (34.7-32.7 Ma); however, in Hole 703A it occurs between the LAD Isthmolithus recurvus and LAD Reticulofenestra umbilica (34.9-34.6 Ma).

Upper Eocene Sample 114-703A-16X-1, 44-46 cm, contains specimens with more robust and nearly cylindrical spines (PI. 8, Fig. 9), which are otherwise similar to this species. They are tabulated separately in tables and figures as B. paulschulzii (cylindrical spines).

\section{Bachmannocena paulschulzii var. 1}

(Pl. 8, Fig. 14)

Remarks. Five specimens, similar to that figured, were found in Sample 114-698A-3R-1, 40-42 cm. These specimens are similar to $B$. paulschulzii, except for the inflated convex sides of the ring. These specimens are from the only lower Eocene sample of Hole 698A not to have undergone diagenesis of biogenic silica; therefore, its geologic range is unknown. It is older than the first occurrence of $B$. paulschulzii in Leg 114 sediments and may be ancestral to it. It occurs in foraminifer Zones P8/9 and the calcareous nannofossil Discoaster sublodoensis Zone (NP14-?15) of the lower Eocene.

Bachmannocena sp. schulzii? (Martini and Müller, 1976) Bukry, 1987

(PI. 8, Fig. 12)

Remarks. A single specimen was found in middle Eocene Sample 114-702B-18X-4, 40-42 cm.

\section{Bachmannocena vetula $\mathrm{n}$. $\mathrm{sp}$.}

(PI. 8, Fig. 16)

Description. This species is characterized by its small size and its age, which differentiates it from other quadrate taxa. Radial spine length is typically 12 to $14 \mu \mathrm{m}$, and the width of the basal ring varies from 27 to $35 \mu \mathrm{m}$. The basal ring has equal sides and exhibits some outward convexity. In light microscopy it appears to have a microornamentation of subparallel ridges.

Remarks. The apparent last occurrence of the species coincides with the first occurrence of Bachmannocena paulschulzii, suggesting that it may be its ancestor. $B$. vetula appears to be the oldest of the quadrate Bachmannocena. Its smaller size differentiates it from the younger $B$. paulschulzii. B. schulzii differs by its concave sides and much larger size ( 75 to $160 \mu \mathrm{m})$.

Occurrence. $B$. vetula occurs within the middle Eocene of Hole 702B. The first occurrence of this species apparently occurs near the foraminifer Zone P10/11 boundary and is within Subchron C21N; however, poor preservation in the lower portion of the section does not preclude an earlier first-appearance datum. The species' firstnoted occurrence is only $3 \mathrm{~m}$ below the LAD Planorotalites pseudoscitulus elongatus, which has a calibrated age in Hole 700B of 48.8 $\mathrm{Ma}$; an approximate age of $49.1 \mathrm{Ma}$ thus is assigned to the FAD of $B$. vetula. Its last occurrence was noted immediately above foraminifer Zone P11 within an interval designated as P12-13 and within Subchron C20N (45.7-45.4 Ma).

Holotype. Paleontologisk Museum, Oslo (PMO) 121,032 (Pl. 8, Fig. 16).

Type locality. Hole 702B, Islas Orcadas Rise, southwest Atlantic sector of the Southern Ocean.

\section{Bachmannocena sp. 1}

$$
\text { (Pl. 8, Fig. 11) }
$$

Remarks. Only one specimen of this almost circular and spineless Bachmannocena was noted in Sample 114-703A-13H-4, 60-62 cm, from the lowermost Oligocene. Three distinct segments to the ring can be noted between hyaline "septate" divisions equally spaced with respect to one another.

\section{Genus CARYOCHA Bukry and Monechi, 1985}

Remarks. The practice of Bukry and Monechi (1985) is employed of not recognizing the genus Cannopilus and including phenotypic varieties with nonglobular and subdivided apical apparatus in Distephanus. The genus Caryocha has a more restrictive geologic range than taxa of Distephanus with a subdivided apical apparatus, the former only being a major component of the assemblage in the lower and middle Miocene. Caryocha is distinctive for its globular form, multiple apical windows, nearly equant basal spines, and a basal ring equal to, or less than, the diameter of the apical structure.

Caryocha depressa (Ehrenberg, 1854) Bukry and Monechi, 1985

Caryocha ichikawai (Bachmann in Ichikawa et al., 1964) Bukry and Monechi, 1985 


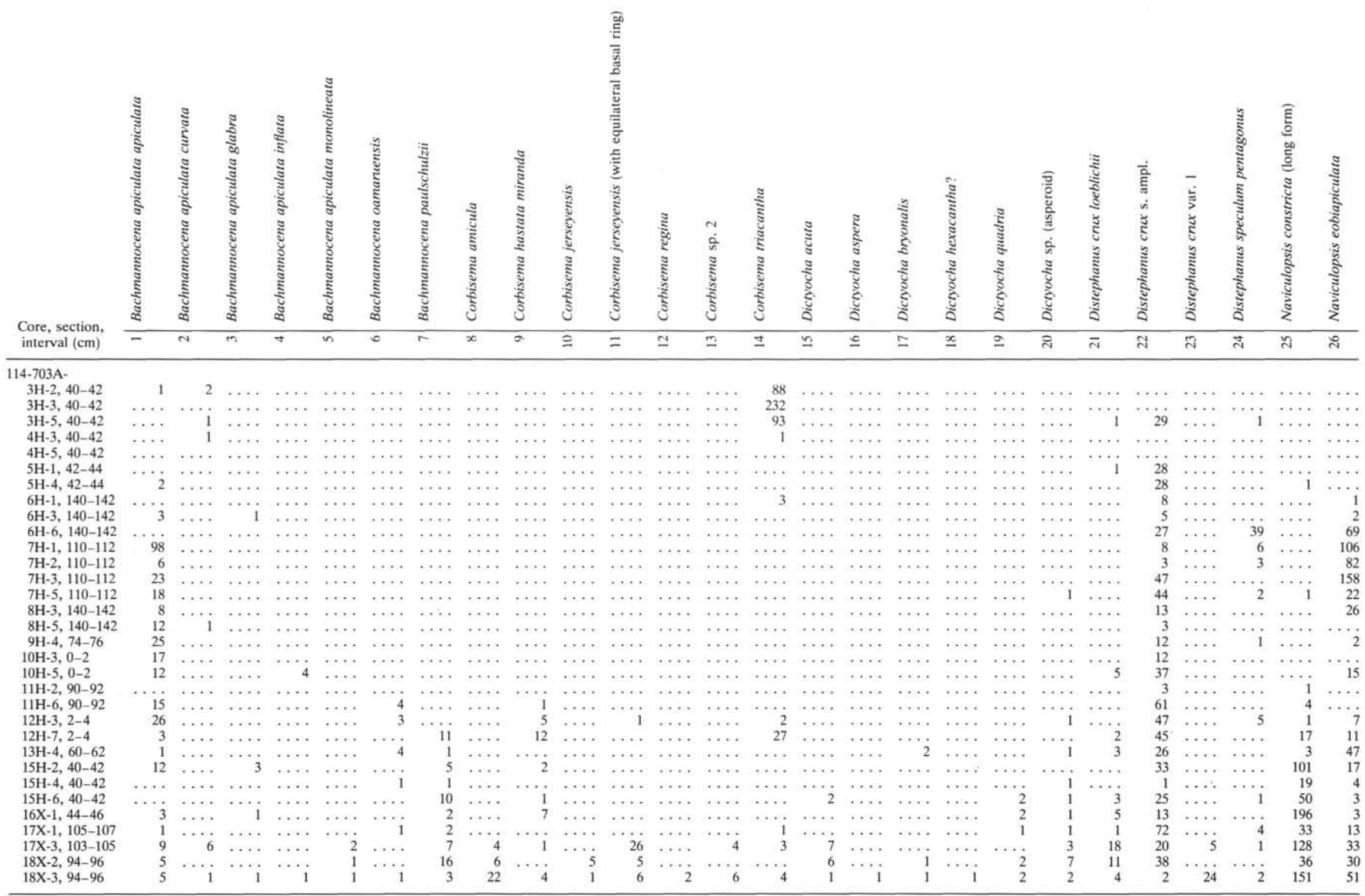

Note: ${ }^{*}=$ very rare, found only after completion of census count of 300 specimens. Shading designates range of uncertainty for zonal boundary. 

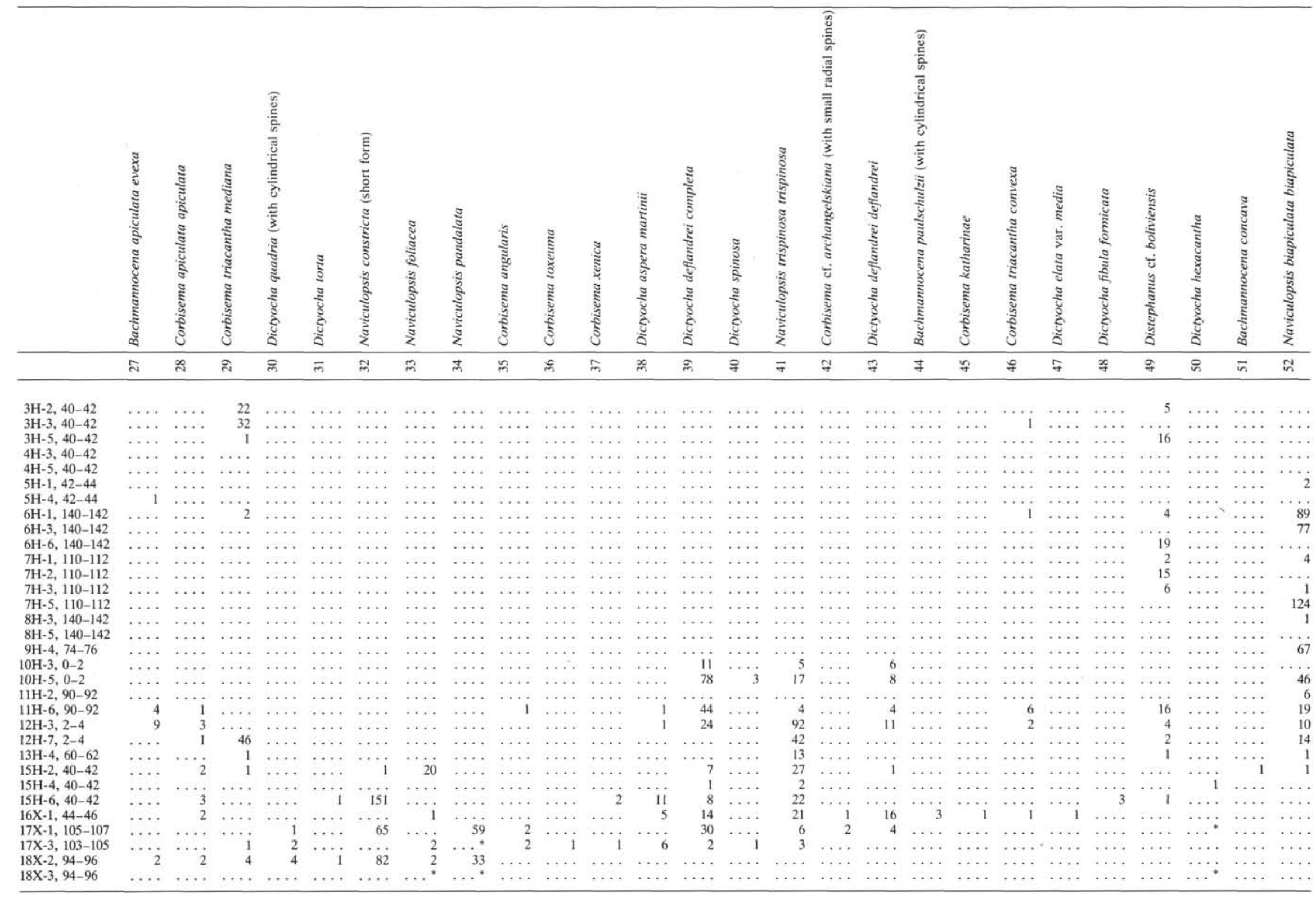


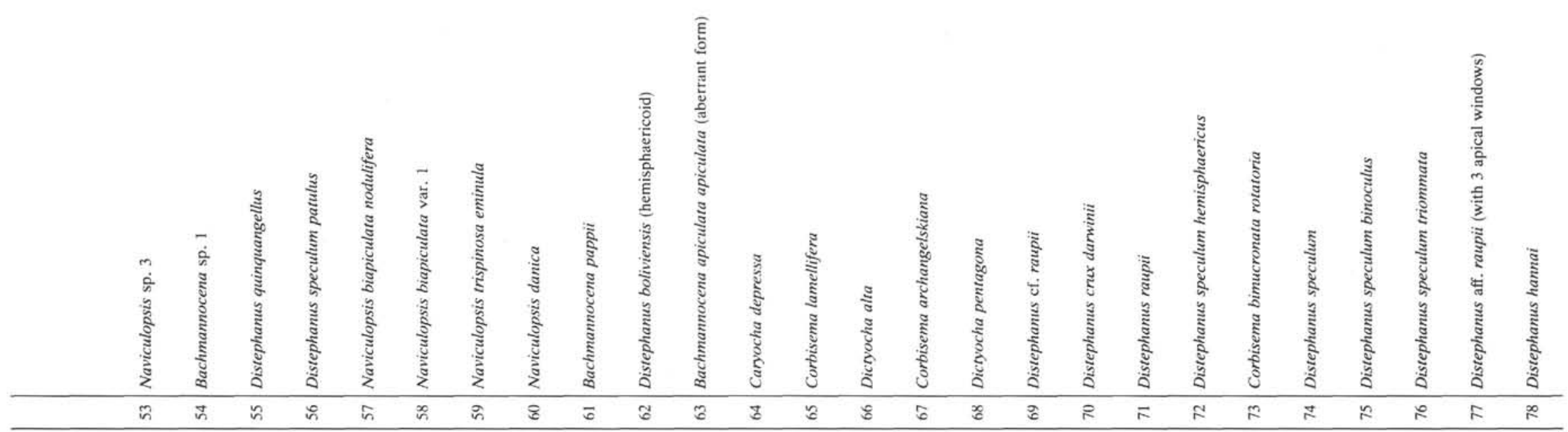

$3 \mathrm{H}-2,40-42$

$3 \mathrm{H}-3,40-42$

$3 \mathrm{H}-5,40-42$

$4 \mathrm{H}-3,40-42$

$4 \mathrm{H}-5,40-42$

$5 \mathrm{H}-1,42-44$
$5 \mathrm{H} \cdot 4,42-44$

$6 \mathrm{H}-1,140-142$

$6 \mathrm{H}-3,140-142$

6H-6, $140-142$

$7 \mathrm{H}-1,110-112$
$7 \mathrm{H}-2,110-112$

$7 \mathrm{H}-3,110-112$

7H-3, 110-112

8H-3, 140-142

$8 \mathrm{H}-5,140-142$

$9 \mathrm{H}-4,74-76$

$10 \mathrm{H}-3,0-2$

$10 \mathrm{H}-5,0-2$

$11 \mathrm{H}-2,90-92$

$11 \mathrm{H}-6,90-92$

$12 \mathrm{H}-3,2-4$

$12 \mathrm{H}-7,2-4$

$13 \mathrm{H}-4,60-62$

$15 \mathrm{H}-2,40-42$

$15 \mathrm{H}-4,40-42$

$15-6,40-42$

$16 \mathrm{X}-1,44-46$

17X-1, 105-107

$17 X-3,103-105$

$18 \times-3,94-96$ 


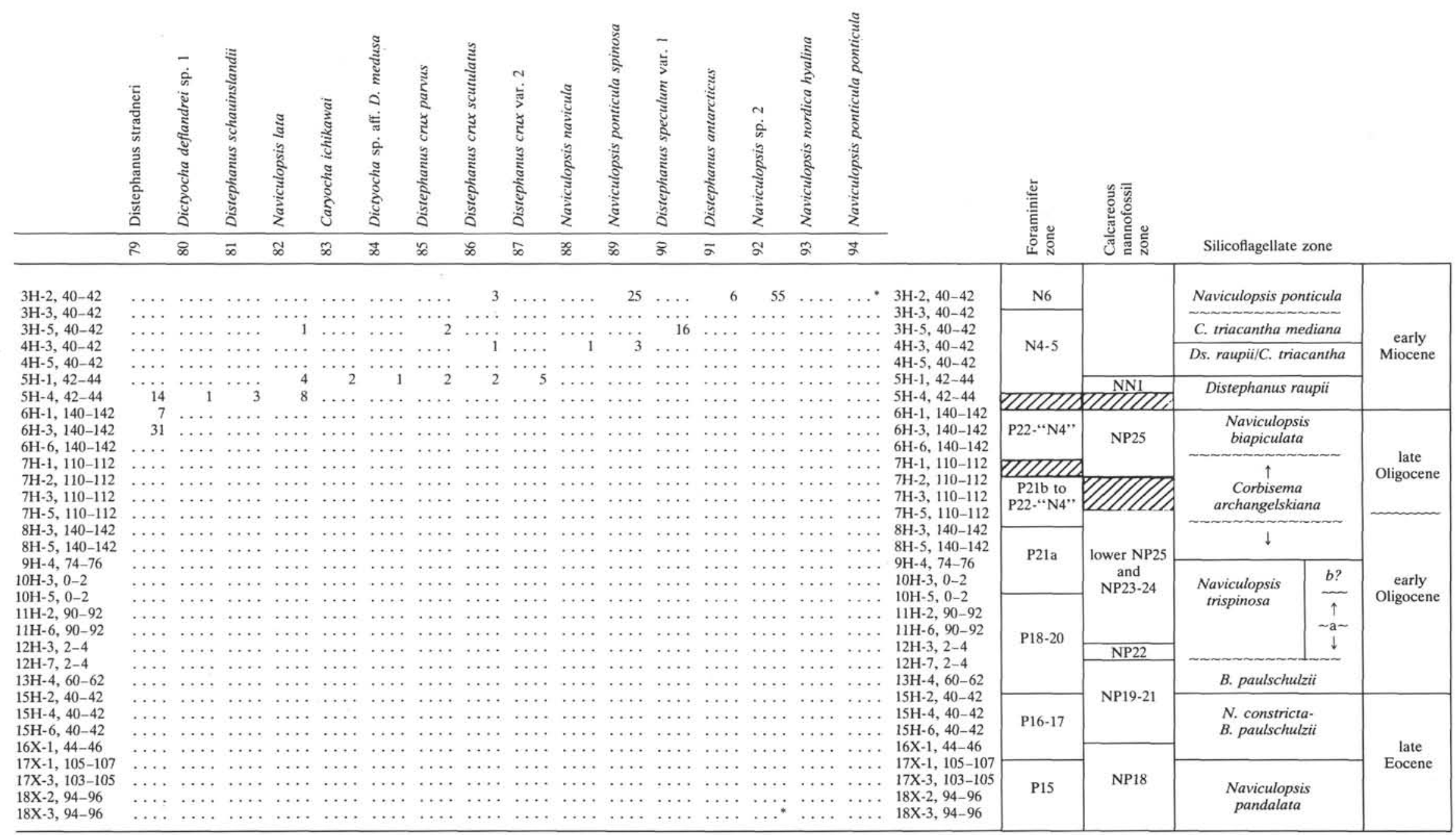




\section{Table 7 (continued).}

Index

$$
\text { Species }
$$

1 Bachmannocena apiculata apiculata

33 Bachmannocena apiculata apiculata (aberrant form)

2 Bachmannocena apiculata curvat

27 Bachmannocena apiculata evexa

3 Bachmannocena apiculata glabra

Bachmannocena apiculata inflata

51 Bachmannocena concava

6 Bachmannocena oamaruensis

61 Bachmannocena pappi

7 Bachmannocena paulschulzii

44 Bachmannocena paulschulzii (with cylindrical spines)

54 Bachmannocena sp. 1

64 Caryocha depressa

83 Caryocha ichikawai

8 Corbisema amicula

35 Corbisema angularis

28 Corbisema apiculata apiculata

67 Corbisema archangelskiana

73 Corbisema bimucronata rotatoria

42 Corbisema cf. archangelskiana (with small radial spines)

9 Corbisema hastata mirand

10 Corbisema jerseyensis

11 Corbisema jerseyensis (with equilateral basal ring)

45 Corbisema katharinae

65 Corbisema lamellifer

12 Corbisema regina

36 Corbisema toxeuma

14 Corbisema triacantha

46 Corbisema triacantha convexa
Index

Species

29 Corbisema triacantha mediana

37 Corbisema xenica

47 Dictyocha elata var. media

15 Dictyocha acuto

66 Dictyocha alta

16 Dictyocha aspera

Dictyocha aspera martini

17 Dictyocha bryonalis

Dictyocha defiandrei completa

3 Dictyocha deflandrei deflandrei

Dictyocha deflandrei sp. 1

Dictyocha fibula formicaia

Dictyocha hexacantha

18 Dictyocha hexacantha?

68 Dictyocha pentagona

Dictyocha quadria

Dictyocha quadria (with cylindrical spines

Dictyocha sp. (asperoid)

Dictyocha sp. aff. D. medusa

40 Dictyocha spinosa

Dictyocha torta

Distephanus aff. raupii (with 3 apical windows)

Distephanus antarcticus

Distephanus boliviensis (hemisphaericoid)

9 Distephanus cf. boliviensi

69 Distephanus cf. raupii

7. Distephanus crux darwinii

Distephanus crux loeblichit

Distephanus crux parvus

26. Distephanus crue s. ampl.
Index

Species

23 Distephanus crux var. 1

87 Distephanus cnux var. 2

78 Distephanus hannai

55 Distepnanus quinquangellus

71 Distephanus raupii

81 Distephanus schauinslandi

74 Distephanus speculum

75 Distephanus speculum binoculus

72 Distephanus speculum hemisphaericus

56 Distephanus speculum patulus

24 Distephanus speculum pentagonus

76 Distephanus speculum triommata

90 Distephanus speculum var. 1

79 Distephanus stradnen

52 Naviculopsis biapiculata biapiculata

57 Naviculopsis biapiculata nodulifer

58 Naviculopsis biapiculata var. 1

25 Naviculopsis constricta (long form)

32 Naviculopsis constricta (short form)

60 Naviculopsis danica

26 Naviculopsis eobiapiculata

33 Naviculopsis foliacea

82 Naviculopsis lata

98 Naviculopsis navicula

34 Naviculopsis pandalata

34 Naviculopsis pandalata
94 Naviculopsis ponticula ponticula

89 Naviculopsis ponticula spinosa

92 Naviculopsis sp. 2

59 Naviculopsis trispinosa emimula

41 Naviculopsis trispinosa trispinosa 
Table 8. Samples from Hole 703A Paleogene sequences that are barren of silicoflagellates.

\begin{tabular}{c}
\hline $\begin{array}{c}\text { Core, section, } \\
\text { interval }(\mathrm{cm})\end{array}$ \\
\hline $114-703 \mathrm{~A}-$ \\
$20 \mathrm{X}-1,140-142$ \\
$20 \mathrm{X}-3,140-142$ \\
$20 \mathrm{X}-5,140-142$ \\
$21 \mathrm{X}-2,110-112$ \\
$21 \mathrm{X}-4,110-112$ \\
$23 \mathrm{X}-1,52-54$ \\
\hline
\end{tabular}

\section{Genus CORBISEMA Hanna, 1928}

Corbisema amicula Bukry, 1987

(PI. 6, Fig. 15)

Remarks. This species occurs only in the lower portion of the biosiliceous section in Hole 703A. Its last occurrence is recorded in Sample 114-703A-17X-3, 103-105 cm, within the upper Eocene foraminifer Zone P10.

Corbisema angularis Bukry in Barron, Bukry, and Poore, 1984

$$
\text { (PI. 6, Fig. 12) }
$$

Remarks. Corbisema angularis was previously reported from the upper middle Eocene (lower Dictyocha hexacantha Zone) of the Kellogg Shale of California by Barron et al. (1984). Herein, a single occurrence was noted from the middle Eocene of Hole 702B within foraminifer Zone P10. Late Eocene forms have slightly indented sides in Sample 114-703A-17X-1, 105-107 cm.

\section{Corbisema animoparallela $\mathrm{n} . \mathrm{sp}$.}

(PI. 2, Figs. 17, 18)

Description. This distinctive species is characterized by dissimilar portals. The basal ring is strongly indented at the strut juncture and shaped to give the appearance of being six-cornered, with most corners sharp rather than rounded. One portal is almost rectangular with the peripheral side straight to slightly concave. The other two portals are unequal in size because of an asymmetrical union of the three struts and are angular to give the appearance of being five-sided. Peripheral sides of these other two lobes exhibit some convexity. The apical bars are slightly elevated and the same diameter as the basal ring. It is unclad (animo = naked, unclad) of an apical plate. No basal accessory spines were observed.

Remarks. Several Late Cretaceous Corbisema species are characterized by a triangular apical plate (Corbisema geometrica and Corbisema parallela), which became reduced and then absent from Paleocene Corbisema. These plate-bearing Corbisema of the Late Cretaceous no doubt gave rise to some of the larger Paleocene Corbisema without this apical plate. C. animoparallela is an example of a probable descendant of plate-bearing stock of the Late Cretaceous. It is very similar to $C$. parallela, which was described by Hajós (1975) from the Upper Cretaceous of Site 275 as "has a basal ring bent so that it appears almost six-cornered. Peripheral stretch of each arc more or less straight and without basal spine. Triangular apical area slightly rounded." C. animoparallela is similar in most respects, except for the one elongated lobe, the absence of an apical plate, and its younger range. One such specimen is Sample 114-700B-27R-1, $60-62 \mathrm{~cm}$ (PI. 2, Fig. 16), which is compared to C. animoparallela; it is identical to $C$. parallela except for the absence of the apical plate. This single specimen may not be in situ.

C. animoparallela may have given rise to Corbisema neoparallela (Bukry, 1976a), which has three six-sided portals.

Occurrence. The first occurrence of $C$. animoparallela is in Sample 114-700B-31R-6, 36-38 cm (62.7 Ma), and it has its last occurrence in Sample $114-700 \mathrm{~B}-29 \mathrm{R}-\mathrm{CC}(60.8 \mathrm{Ma})$. Thus, the range of the species is limited to the uppermost lower to lower upper Paleocene of Chron C26. Its first occurrence is near the boundary of the calcareous nannofossil Fasiculithus tympaniformis Zone and Prinsius bisulcus
Zone and in foraminifer Zone P2. Its last occurrence is in the calcareous nannofossil Heliolithus kleinpellii Zone (NP6-7) and the lower portion of foraminifer Zone P4.

Holotype. PMO 121,033 (Pl. 2, Figs. 17, 18).

Type locality. Hole 700B, Northeast Georgia Rise, southwest Atlantic sector of the Southern Ocean.

Corbisema apiculata apiculata (Lemmermann, 1901) Hanna, 1931

Remarks. This species occurs in the Paleocene through lower Oligocene of Sites 698,700 , and 703. Its last occurrence is recorded in Sample 114-703A-11H-6, 90-92 cm, in Subchron C12R of the lower Oligocene. Bracketing samples of this datum also bracket a disconformity, thereby leaving a wide age range for its occurrence (34.6$32.9 \mathrm{Ma}$ ). The specimen in Pl. 3, Fig. 5, is compared to Corbisema apiculata, but differs in its very inflated and evenly rounded lobes.

\section{Corbisema apiculata (with thin apical bars)}

$$
\text { (PI. 2, Figs. 12, 13) }
$$

Remarks. The figured specimen appears to be an intraspecific variation of Corbisema apiculata, which is characterized by very thin, threadlike struts that are easily broken. The strut diameter, when sharply focused upon, is less than one-half the diameter of the basal ring thickness. Rare occurrences were noted in the middle Eocene of Hole 702B within the calcareous nannofossil Discoaster lodoensis and Discoaster sublodoensis Zones and foraminifer Zones P10-11.

Corbisema archangelskiana (Schulz, 1928) Frenguelli, 1940

Remarks. Corbisema archangelskiana was recorded in the Paleocene of Hole 700B and in the upper Eocene-Oligocene of Hole $703 \mathrm{~A}$. The last occurrence of the species is recorded in Hole 699A between the top of Subchron C6CN (24.04) to just below the Subchron C6CN/C6CR boundary $(24.21 \mathrm{Ma})$ at $\sim 24.3 \mathrm{Ma}$.

\section{Corbisema cf. archangelskiana (with small radial spines)}

Remarks. Schulz (1928) mentioned the lack of radial spines in his description of the species, yet figured one specimen (fig. 21) with spines. Perch-Nielsen (1976a) suggested that only spineless forms be attributed to Corbisema archangelskiana and other workers have generally followed this advice. For this reason, spined varieties found here are referred to as Corbisema cf. archangelskiana. This form appears to arise simultaneously with the unspined varieties; however, its last occurrence at the Leg 114 sites appears to be in the upper Eocene rather than in the upper Oligocene, as is the case with the unspined $C$. archangelskiana. C. cf. archangelskiana occurs in Holes $700 \mathrm{~B}, 702 \mathrm{~B}$, and $703 \mathrm{~A}$.

Corbisema cf. archangelskiana (with small radial spines and minor strut indentation)

Corbisema cf. archangelskiana Martini and Müller, 1976, p. 869, pl. 7, fig. 5 .

Corbisema archangelskiana Perch-Nielsen, 1976a, p. 684, pl. 3, fig. 22.

Remarks. This is similar to Corbisema cf. archangelskiana (with small radial spines), except for a distinctly smaller amount of indentation of the basal ring where it joins the lateral rods. It was found only in Sample 114-700B-32R-4, 42-44 cm.

\section{Corbisema bimucronata bimucronata Deflandre, 1950}

Remarks. Rare occurrences of this species were noted in Hole 700B (Table 3 and Fig. 5) within the calcareous nannofossil Heliolithus riedellii Zone (NP8) of the upper Paleocene.

\section{Corbisema bimucronata rotatoria Bukry, 1978a}

Remarks. A single occurrence of this species was noted in Oligocene Sample 114-703A-7H-5, 110-112 cm, within the calcareous nannofossil Chiasmolithus altus Zone.

\section{Corbisema camera $\mathrm{n}$. $\mathrm{sp}$.}

(Pl. 4, Figs. 3-6)

Description. This distinctive new species is typified by its highly arched apical apparatus, consisting of three lateral rods that descend from their juncture at the highest point of the apical apparatus to the midpoint of the basal ring. The elevation of the apical apparatus 
requires a strong downward curvature of the lateral rods to join the basal ring. The three lateral rods equally divide the basal area; however, the strong curvature of the lateral rods gives the appearance of unequal division when observed at an oblique angle (PI. 4, Figs. 5, $6)$. The basal ring is an equilateral triangle with moderate length spines. The entire skeleton is robust and large as compared with other triangular Corbisema species of the Paleocene.

Remarks. This species is easily distinguished from other Paleocene triangular Corbisema by its large size, robustness, and highly arched apical apparatus.

Occurrence. Hole 700B, between Samples 114-700B-28R-4, 116$118 \mathrm{~cm}$, and 114-700B-31R-7, 40-42 cm, contains consistent occurrences of the species $(<1 \%-6 \%)$. The geologic range extends from upper lower Paleocene to middle upper Paleocene, including the Heliolithus riedellii Zone through Prinsius bisulcus Zone, foraminifer Zone P3 and portions of Zones P2 and P4, and a portion of Subchron C25R and most of Subchron C26R. Above Sample 114-700B-29R-CC only a rare occurrence was noted; therefore, this sample may mark its last occurrence as well as its last consistent occurrence.

Holotype. PMO 121,034 (Pl. 4, Figs. 3, 4).

Isotype. PMO 121,035 (PI. 4, Figs. 5, 6).

Type locality. Northeast Georgia Rise, southwest Atlantic sector of the Southern Ocean.

Corbisema constricta constricta (Busen and Wise, 1977) Ling, 1981 emended

(Pl. 2, Figs. 1, 2, 8; Pl. 3, Figs. 9, 10)

Corbisema disymmetrica communis Bukry, 1976a (in part), p. 891, pl. 1, figs. 7-9 (only).

Corbisema navicula constricta Busen and Wise, 1977, p. 712, pl. 3, figs. 1,2

Corbisema constricta Ling, 1981, pl. 1, figs. 5-7, text fig. 1 .

Remarks. Bukry (1976a) included this as a subspecies of Corbisema disymmetrica although it does not bear the distinctive thick and corrugated skeletal components of Corbisema disymmetrica disymmetrica. This author concurs with Ling's (1981) opinion that it warrants separate taxonomic status and the rejection of the name Corbisema disymmetrica communis in favor of the junior synonym, which was elevated to a separate species status by Ling (1981).

The holotype and subsequent description by Ling (1981) cite the absence of axial spines. Specimens found in this study with axial spines are otherwise identical to Corbisema constricta (compare PI. 3, Fig. 10, with Pl. 3, Figs. 11, 12). Forms with axial spines occur entirely within the range of $C$. constricta and would appear to be a subspecies based on its range and otherwise identical form. For this reason, the species Corbisema constricta is emended to include forms with axial spines, the subspecies Corbisema constricta spinosa. The subspecies Corbisema constricta constricta is to be applied to spineless forms. Some specimens exhibit a micro-ornamentation of subparallel ridges.

Occurrence. C. constricta constricta was found in Paleogene samples from Holes 698A, 700B, and 702B. The first occurrence of the species occurs in the calcareous nannofossil Prinsius martini Zone and below the Chron $\mathrm{C} 26 / \mathrm{C} 27$ boundary $(63.03 \mathrm{Ma})$. The last occurrence of this species is in Hole 702B, within the Nannotetrina fulgens Zone and Subchron C20N of the middle Eocene.

\section{Corbisema constricta spinosa $\mathrm{n}$. subsp.}

(PI. 1, Fig. 8; PI. 3, Figs. 7, 8, 11, 12)

Description. This subspecies is identical to Corbisema constricta constricta, except for the presence of axial spines. The basal ring is bilobate with broadly rounded apices. The lateral bar is thinner than the basal ring and is slightly arched, joining the basal ring where there is a constriction to the ring. The axial spines are short and basal accessory spines absent or short and thin. The widest dimension of the basal ring is generally midway between the constriction and axial spine. Basal ring ornamentation is highly variable.

Remarks. Corbisema constricta spinosa differs from $C$. constricta constricta by the presence of axial spines (see preceding discussion of C. constricta constricta).

Occurrence. This subspecies has a limited geologic range, restricted to Samples 114-700B-29R-1, 39-40 cm (60.19 Ma), and
114-700B-29R-2, $37-38 \mathrm{~cm}(60.15 \mathrm{Ma})$, where it accounts for $2 \%$ to $3 \%$ of the assemblage. These samples occur within the Heliolithus riedellii Zone and the planktonic foraminifer Zone P4. An isolated occurrence was noted in Sample 114-700B-30R-2, $118-120 \mathrm{~cm}(61.51 \mathrm{Ma})$.

Holotype. PMO 121,036 (PI. 3, Figs. 11, 12).

Isotypes. PMO 121,037 (Pl. 1, Fig. 8), PMO 121,038 (Pl. 3, Fig. 7), and PMO 121,039 (PI. 3, Fig. 8).

Type locality. Hole 700B, Northeast Georgia Rise, southwest Atlantic sector of the Southern Ocean.

Corbisema cuspis Busen and Wise, 1977

?Corbisema inermus ssp. disymmetrica Dumitrică, 1973 (in part), p. 846 , pl. 12 , fig. 3 .

Corbisema disymmetrica angulata Bukry, 1976a, p. 891, pl. 1, figs. $1-4$.

Corbisema cuspis Busen and Wise, 1977, p. 711, pl. 1, figs. 4-6.

Corbisema cuspis Ling, 1981, pp. 3-4, pl. 1, fig. 4.

Remarks. Ling (1981) discussed the taxonomic status of this species in detail. This author concurs with Ling's recommendation to reject the name Corbisema disymmetrica angulata (Bukry, 1976a), which has priority over Corbisema cuspis (Busen and Wise, 1977). C. cuspis lacks the thick, corrugated microstructure originally applied by Dumitricá (1973) to the subspecies that Bukry (1976a) elevated to the rank of species (Corbisema disymmetrica). In addition, C. cuspis appears to be confined to the upper Paleocene and above the range of Corbisema disymmetrica disymmetrica. In the present study $C$. cuspis is rare and limited to the upper Paleocene Heliolithus riedellii Zone of Hole 700B.

\section{Corbisema delicata $\mathrm{n} . \mathrm{sp}$.}

(PI. 3, Figs. 1-4)

Description. Corbisema delicata may have an equilateral-to-isosceles triangular basal ring. Most specimens have one side of the ring that exhibits greater convexity than the others, commonly creating a lopsided appearance to the ring (PI. 3, Figs. 3, 4). Very small radial spines occur at the septate corners of the basal ring. The basal ring appears to have a fine pustulate micro-ornamentation. The lateral rods are slightly elevated above the plane of the basal ring and are exceptionally thin and threadlike in appearance. These lateral rods are one-half or less the thickness of the basal ring and are seldom straight; instead, they are bowed or wavy in appearance. Basal accessory spines appear to be absent.

Remarks. C. delicata may have evolved from Corbisema geometrica through the loss of the apical plate and other minor skeletal alterations. Some specimens of $C$. geometrica have lateral rods almost as thin as $C$. delicata.

Occurrence. This species is confined to the lower Paleocene of Hole 700B, where it occurs in Samples 114-700B-32R-5, 40-42 cm, and 114-700B-32R-4, 42-44 cm. These samples are in foraminifer Zone P1c and lower Zone P2, as well as in the calcareous nannofossil Prinsius martini Zone. The short range of this species is below the Chron C26/C27 boundary (63.03 Ma) and above the Chron C28/C29 boundary $(65.50 \mathrm{Ma})$.

Holotype. PMO 121,040 (PI. 3, Figs. 1, 2).

Isotype. PMO 121,041 (PI. 3, Figs. 3, 4).

Type locality. Hole 700B, Northeast Georgia Rise, southwest South Atlantic sector of the Southern Ocean.

Corbisema disymmetrica crenulata (Bukry, 1976a) n. comb. (Pl. 1, Figs. 1, 2)

Dictyocha triacantha var. inermus f. inermus Glezer, 1966 (in part), p. 230 , pl. 8, figs. 1(?), 2(?) (only).

Corbisema inermus Dumitrică 1973 , p. 845 , pl. 12, figs. 7-9.

Corbisema inermus crenulata Bukry, 1976a, p. 892.

Corbisema inermus inermus Busen and Wise, 1977, p. 711, pl. 2, fig. 5.

Crassicorbisema disymmetrica dumitricae Ling, 1981, pp. 5-6.

Remarks. Bukry (1976a) assigned this distinctive silicoflagellate with a crenulate surface texture as a subspecies of Corbisema inermus, rather than as a subspecies of Corbisema disymmetrica. In spite of similarities in the ornamentation and thickness of the skeletal elements, Bukry (1976a) did not assign this taxa to $C$. disymmetrica 
because of its separate geologic range and thinner apical bar without crenulation.

The occurrence of this rounded triangular crenulate species in Hole 700B clarifies its taxonomic position. It is rare in two lower Paleocene samples, which are assigned to foraminifer Zone P2, and has its first occurrence with that of Corbisema disymmetrica disymmetrica. As a consequence, $C$. disymmetrica disymmetrica is not restricted to the upper Paleocene and the earlier portion of its range is concurrent with the range of Corbisema disymmetrica crenulata, thus eliminating the separate range criteria used by Bukry to assign them to separate taxa. Furthermore, $C$. disymmetrica crenulata exhibits similar variability in the characteristics of the apical bridge, as does $C$. disymmetrica disymmetrica. Both may have apical bridges significantly thinner than the basal ring or may have a robust, gradually tapering bar with ornamentation similar to the basal ring. Partially overlapping geologic ranges, the large robust size, and the similarity of ornamentation clearly reveal a close genetic relation between $C$. disymmetrica disymmetrica and $C$. disymmetrica crenulata. For this reason, Corbisema inermus crenulata has been reassigned as a subspecies of $C$. disymmetrica.

C. disymmetrica crenulata appears restricted to the lower $\mathrm{Pa}-$ leocene of Hole 700B. It occurs in the lower Paleocene calcareous nannofossil Cruciplacolithus tenuis Zone at Site 208 on the Lord Howe Rise. Other very rare occurrences in the upper Paleocene of Holes 277A and 327A are considered to be reworked (see Ling, 1981). A single reworked occurrence is in the upper Paleocene of Hole 700B.

Corbisema disymmetrica disymmetrica (Dumitrică, 1973) Bukry, $1976 \mathrm{a}$

(PI. 1, Figs. 3-6, 7?, 9?)

Corbisema inermus disymmetrica Dumitrică, 1973 (in part), p. 846, pl. 12, figs. 1, 2, 4-6 (only); pl. 13, figs. 1-8.

Corbisema inermus disymmetrica Perch-Nielsen, 1976a, p. 685, pl. 8 , figs. $1,2$.

Corbisema inermus disymmetrica Busen and Wise, 1977, p. 711, pl. 2, fig. 6.

Corbisema disymmetrica disymmetrica Bukry, 1976a, p. 891, pl. 1, figs. 10-12.

Crassicorbisema disymmetrica disymmetrica Ling, 1981, pp. 6-7, pl. 1 , figs. 8-12.

Remarks. This large robust species first occurs in the lower Paleocene within Sample 114-700B-32R-2, 35-37 cm, immediately above the Subchron C26R/C27N boundary (63.03 Ma) in Section 114-700B-32R-3. It is abundant only shortly above its initial occurrence in foraminifer Zone P2, but is consistently present into Chron $\mathrm{C} 26$. It is rare to very rare in two upper Paleocene samples above its last consistent occurrence. Ling (in Ciesielski, Kristoffersen, et al., 1988) also observed the species in Samples 114-702B-31X-CC and 114-702B-32X-CC; however, it was not noted in other samples from these cores in the present study. These later occurrences, if in situ, occur within the calcareous nannofossil Heliolithus kleinpellii Zone and Fasiculithus typaniformis Zone and foraminifer P3a and P3b Zones.

Some specimens in Hole 700B exhibit extremely long accessory spines so as to give the appearance of double apical bars in an oblique apical view.

\section{Corbisema falklandensis Bukry, 1976a}

$$
\text { (PI. 4, Figs. 7, 8) }
$$

Remarks. Corbisema falklandensis occurs in Holes 698A and $700 \mathrm{~B}$. In the more complete Hole 700B section, the entire range of the species is recorded. Although rare, it is consistently present between Subchrons C26R and C23R. It ranges from the upper foraminifer Zone P2 to upper Zone P4.

\section{Corbisema falklandensis var. 1}

Remarks. Corbisema falklandensis var. 1 is similar to Corbisema falklandensis in the structure of the basal apparatus, which is pearshaped with a short radial spine at the apex of the basal ring. Arching lamelliform projections with bifurcated terminations occupy the position of the basal accessory spines. It differs from $C$. falklandensis in the structure of the apical apparatus, which is not a triangular plate supported by struts, but comprises three centrally located struts that each bifurcate to form a total of six struts merging with the basal ring. It is found only in the upper part of the range of $C$. falklandensis (Table 3) in Hole 700B and within the calcareous nannofossil Heliolithus riedellii and Heliolithus kleinpellii Zones and foraminifer Zone P4.

\section{Corbisema falklandensis var. 2}

Remarks. This is similar to Corbisema falklandensis except for the apical structure, which consists of contorted, looping apical struts, forming an average of five irregularly shaped apical windows. Corbisema falklandensis var. 2 was found only in Sample 114-700B-30R$1,99-101 \mathrm{~cm}(61.38 \mathrm{Ma})$.

\section{Corbisema falklandensis var. 3}

Remarks. Corbisema falklandensis var. 3 is similar to Corbisema falklandensis var. 1 except that the three centrally located struts comprising the apical apparatus do not bifurcate. Two specimens were observed in Sample 114-698A-3R-1, 40-42 cm.

\section{Corbisema flexuosa (Stradner, 1961) Perch-Nielsen, 1976}

Corbisema cf. flexuosa (Stradner, 1961) Perch-Nielsen, 1976a (Pl. 6, Fig. 7)

Corbisema flexuosa Martini and Müller, 1976, pl. 7, fig. 7.

Remarks. A single specimen found in Sample 114-700B-31R-1, $29-31 \mathrm{~cm}$, is similar to Corbisema flexuosa but lacks the common apical plate structure. This Paleocene specimen is older than the known range of $C$. flexuosa and may be a variant of Corbisema archangelskiana.

\section{Corbisema geometrica Hanna, 1928}

Remarks. A single specimen was noted within the Paleocene of Hole 700B (Table 2) and is interpreted as reworked. Otherwise absent from the lower Paleocene sediments of this site, this Cretaceous species cannot range higher into the lower Paleocene than 63.2 Ma.

\section{Corbisema glezerae Bukry, 1976a}

$$
\text { (PI. 6, Figs. 16, 17) }
$$

Remarks. This species is one of the most abundant in the Paleocene of Hole $700 \mathrm{~B}$, where its entire range is recorded. The first occurrence of the species occurs in the lower Paleocene (62.7 Ma) within the foraminifer P2 Zone and in Subchron C26R. The last occurrence is within upper foraminifer Zone P4 and in Subchron C23R.

\section{Corbisema hastata alta $\mathrm{n}$. subsp.}

$$
\text { (Pl. 4, Figs. 1, 2; Pl. 9, Fig. 10) }
$$

Description. This species is characterized by the extreme elongation of the basal ring, which in general has a length-to-width ratio of $\sim 2: 1$. Most specimens exhibit two long sides that are convex with a slight indentation where the apical rods join the basal ring. The third side of the basal ring is generally strongly indented where the third apical rod joins the ring. Two spines are of moderate length, and the third spine on the strongly indented side is usually shorter to much shorter than the others. The apical apparatus of three rods is slightly elevated. The rod merging with the strongly indented side of the basal ring, asymmetrically disposed toward the shorter spine, is typically asymmetric where it joins the other rods. Small accessory spines or buds occur where the lateral rods join the abapical side of the basal ring.

Toward the upper part of its range this species exhibits more examples of reduction of the third spine, loss of basal ring indentation, and an increase in the length-to-width ratio. Morphotypes of this type (PI. 9, Fig. 10) closely resemble Naviculopsis primativa n. sp. (compare with Pl. 9, Fig. 9) in size and shape of the body ring, apical structure, and spine length, except for the remnant short spine.

Remarks. The greatest abundance of the species $(36 \%)$ occurs in Sample 114-700B-30R-3, 106-108 cm (61.6 Ma). This occurrence is immediately below the first occurrence of $N$. primativa (Sample 114-700B-30R-2, 118-120 cm), which so closely resembles Corbisema hastata alta. Based upon the morphologic similarities of these species it seems likely that $C$. hastata alta was the direct ancestor to $N$. primativa and the progenitor of the genus Naviculopsis. 
Occurrence. C. hastata alta occurs in the Paleocene of Hole 700B, ranging from Samples 114-700B-32R-3, 40-42 cm, to 114-700B-30R-2, $118-120 \mathrm{~cm}$, except for an isolated occurrence in Sample 114-700B$28 \mathrm{R}-4,116-118 \mathrm{~cm}$, which may be reworked. Its interval of consistent occurrence ranges from 63.0 to $61.5 \mathrm{Ma}$, occurring from the calcareous nannofossil Prinsius martini Zone to near the boundary between the Heliolithus kleinpellii and Heliolithus riedellii Zone and from foraminifer Zones P2 to lower Zone P4.

Holotype. PMO 121,042 (PI. 4, Figs. 1, 2).

Isotype. PMO 121,043 (Pl. 9, Fig. 10).

Type locality. Northeast Georgia Rise, southwest Atlantic sector of the Southern Ocean.

\section{Corbisema hastata cunicula Bukry, 1976a}

Remarks. The first occurrence of the species is documented in Hole 700B within Subchron C26R (62.3 Ma) and ranges throughout the Paleocene. A single rare occurrence was noted in the middle Eocene of Hole $702 \mathrm{~B}$.

\section{Corbisema hastata globulata Bukry, 1976a}

(Pl. 6, Figs. 13, 14)

Remarks. This species ranges throughout most of the Paleocene and is particularly common in the upper Paleocene. It is present in the basal sample of the Paleocene in Hole 700B containing silicoflagellates, which is in the calcareous nannofossil Prinsius martini Zone and foraminifer Zone PIc. It is frequent to common in and above Chron C26. The youngest noted occurrence was in Sample 114-698A-3R-1, $40-42 \mathrm{~cm}$, which is near the boundary between the Discoaster lodoensis and Discoaster sublodoensis Zones.

Corbisema hastata hastata (Lemmermann, 1901) Bukry, 1976a

Corbisema hastata incohata Bukry, 1987

(PI. 6, Fig. 11)

Corbisema hastata miranda Bukry in Barron, Bukry, and Poore, 1984

Corbisema hastata (with small basal spines)

Remarks. An apparent variant of Corbisema hastata but with short basal spines, occurring in only the older silicoflagellate-bearing portion of Hole 700B between Samples 114-700B-32R-5, 40-42 cm, and 114-700B-32R-1, 32-40 cm (63.2-62.8 Ma).

\section{Corbisema hastata var. 1}

$$
\text { (Pl. 6, Fig. 10). }
$$

Remarks. This apparent intraspecific variant was noted only in Sample 114-698A-3R-1, 40-42 cm. A distinctive set of basal ring accessory spines occurs adjacent to the radial spine, which is opposite the short side. One short basal ring accessory spine projects at a $45^{\circ}$ angle from the base of the radial spine.

\section{Corbisema hastata var. 2}

Remarks. This variant of Corbisema hastata occurs only in Sample 114-700B-31R-6, 36-38 cm (62.6 Ma), where 35 specimens were noted. It has an isosceles triangular basal ring. The short side of the basal ring is concave and averages $\sim 33 \mu \mathrm{m}$. The other two sides have an average length of $50 \mu \mathrm{m}$ and are moderately indented where they join the lateral rods. Lobes adjacent to the short side are very inflated, with a width of $\sim 40-42 \mu \mathrm{m}$ between these inflated sides. The lateral rods are slightly elevated and symmetric. It possesses short radial spines and basal accessory spines.

\section{Corbisema inermus inermus (Lemmermann, 1901) Bukry, 1976a}

$$
\text { (PI. 3, Fig. 6) }
$$

Remarks. The main occurrence of this species is within the Paleocene of Holes 698A and 700B. It is absent in the single lower Eocene silicoflagellate-bearing sample from Hole 698A and only a single occurrence was noted in the middle Eocene of Hole 702B. It is present throughout the biosiliceous Paleocene section of Hole $700 \mathrm{~B}$, except in Sample 114-700B-26R-2, 78-80 cm, where its absence is due to dissolution. The species is rare in the lower Paleocene, but generally is common to abundant in and above Chron C26.

\section{Corbisema inermus minor (Glezer, 1966) Bukry, 1976a}

$$
\text { (Pl. 4, Figs. 16, 17) }
$$

Remarks. This rare species was found sporadically between Samples 114-700B-28R-4, 116-118 cm, and 114-700B-31R-3, 9-11 cm. These occurrences are limited to the lower and middle portion of the upper Paleocene (foraminifer Zones P3a to P4).

\section{Corbisema inermus var. 1 (bar diameter $>$ ring diameter)}

Remarks. This variety of Corbisema inermus differs by the presence of apical bars with a diameter that exceeds that of the basal ring. Most specimens of other varieties of this species encountered here have a thin to threadlike apical bar. Only one specimen with a bar thicker than that of the ring was found in Sample 114-700B-29R-1, $39-40 \mathrm{~cm}(60.2 \mathrm{Ma})$.

\section{Corbisema inermus var. 2}

$$
\text { (PI. 2, Figs. 6, 7?) }
$$

Remarks. This apparent variety of Corbisema inermus has a short geologic range within the Paleocene of Hole $700 \mathrm{~B}$, making it a potentially useful stratigraphic marker. It is characterized by having two parallel-to-subparallel sides to each of the three lobes. The ends of two or three of the lobes are straight and perpendicular to the the adjacent sides of each lobe. One lobe is typically smaller than the other two. It possesses slightly elevated lateral rods thinner than the basal ring. Basal accessory spines are present and project inward in the abapical direction. Other than a single rare occurrence in the lower Paleocene, its range is limited to Chron C26.

\section{Corbisema jerseyensis Bukry, 1987 (emended herein)}

Remarks. Specimens identical to Bukry's (1987) description of the species were noted in Samples 114-703A-18X-2, 94-96 cm, and $114-703 \mathrm{~A}-18 \mathrm{X}-3,94-96 \mathrm{~cm}$. Additional specimens found to range concurrently to slightly above (to Sample 114-703A-17X-3, 103-105 $\mathrm{cm}$ ) differ only by having an equilateral to nearly equilateral basal ring; it is listed in tables and figures as Corbisema jerseyensis (with equilateral sides). These latter specimens are similar to one of Bukry's isotypes (pl. 5, fig. 3). Because of the concurrent range, overall similarity, and the equilateral nature of one of the isotypes, the species is hereby emended to included specimens with an equilateral or isosceles basal ring.

\section{Corbisema jerseyensis Bukry, 1987 (emended herein) (with equilateral basal ring)}

Remarks. As noted previously, the species has been emended to include related morphotypes with an equilateral basal ring. Equilateral forms are tabulated separately in figures and tables to illustrate the similar stratigraphic range to isosceles forms, which are listed as Corbisema jerseyensis.

\section{Corbisema katharinae Bukry, 1976b}

(Pl. 6, Figs. 8, 9)

Remarks. Corbisema katharinae was found in only Sample 114$703 \mathrm{~A}-16 \mathrm{X}-1,44-46 \mathrm{~cm}$. The figured specimen fits the description of Bukry (1976b) except for the absence of an apical plate, which is similarly absent in one of the isotypes (pl. 1, fig. 2). The other characteristics are identical to the type specimens, including shape of basal ring and irregularity, portal shape, radial spine length and placement, and basal accessory spines.

Corbisema lamellifera (Glezer, 1962) Bukry, 1977

Corbisema lateradiata (Schulz, 1928) Perch-Nielsen, 1976a

Corbisema naviculoidea Perch-Nielsen, 1976b

(Pl. 2, Figs. 3, 4, 5?)

Corbisema naviculoidea Perch-Nielsen, 1976b, p. 33, figs. 7, 9, 22.

Corbisema navicula navicula Busen and Wise, 1977, p. 712, pl. 2, figs. $7 ?, 8,9$.

Corbisema naviculoidea, Ling, 1981, p. 3, pl. 1, fig. 3, text fig. 1 .

Remarks. The first valid description of the species was by PerchNielsen (1976b) although it was figured in earlier publications. The species is apparently restricted to the upper Paleocene; a single specimen found in the lower Paleocene is probably downhole contam- 
ination. It is consistently present between Samples 114-700B-29R-2, $37-38 \mathrm{~cm}$, and $114-700 \mathrm{~B}-28 \mathrm{R}-1,116-118 \mathrm{~cm}(60.7-59.6 \mathrm{Ma})$. The relatively short range of the species is entirely within foraminifer Zone P4 and the calcareous nannofossil Heliolithus riedellii Zone (NP8). Its first consistent occurrence is $1 \mathrm{~m}$ or less below the Chron C25/C26 boundary $(60.21 \mathrm{Ma})$.

\section{Corbisema aff. naviculoidea}

Remarks. Two specimens were found in the upper Paleocene of Hole 700B, within the range of Corbisema naviculoidea, which are probably intraspecific variants. These specimens have a rectangular basal ring; a thin, slightly arched apical bar; no axial spines; and abapical basal accessory spines.

\section{Corbisema sp. cf. Corbisema naviculoidea

$$
\text { (P1. 2, Fig. 9) }
$$

Remarks. Specimens similar to the one figured here were encountered only within Sample 114-700B-28R-4, 116-118 cm (59.9 Ma), of the upper Paleocene. These specimens are strongly constricted where the very short strut merges with the basal ring, giving the skeleton a figure-eight appearance. There is some dissimiliarity in the portal sizes. It possesses inwardly directed basal accessory spines pointing in the abapical direction. One or two specimens have a small bump or "pre-spine" on one apex. It lacks the broadly rounded apices of Corbisema constricta, is more constricted, and has a greater lengthto-width ratio. It is compared to Corbisema naviculoidea because of the more similar length-to-width ratio and more narrowly rounded apices. Its overall characteristics appear intermediate to the two species.

\section{Corbisema praedelicata $\mathrm{n} . \mathrm{sp}$.}

(Pl. 2, Figs. 14, 15)

Description. This small lower Paleocene species has an asymmetric basal ring and thin, fragile lateral rods. One-half of the basal ring is a smooth arc with one lateral rod merging near the midpoint of the arc with little or no constriction. The other half of the basal ring is irregular with one relatively straight segment and another segment exhibiting concavity. The basal ring shape and lateral rod placement result in unequal portals. The lateral rods are similar to Corbisema delicata, one-half to one-third of the ring thickness, fragile and "threadlike," and wavy. Lateral rods appear to be on the same plane as the basal ring. Basal accessory spines were not observed. The basal ring appears to have a micro-ornamentation similar to that of Corbisema disymmetrica but is much finer.

Remarks. This species differs from $C$. delicata by its smaller size, lack of basal ring spines, and more irregular shape of the basal ring.

Occurrence. It is present only in lower Paleocene Sample 114700B-32R-5, 40-42 cm (63.2 Ma). This sample is older than the Chron $\mathrm{C} 26 / \mathrm{C} 27$ boundary $(63.03 \mathrm{Ma})$ and is within the calcareous nannofossil Prinsius martini Zone and foraminifer Zone P1c.

Holotype. PMO 121,044 (PI. 2, Figs. 14, 15).

Type locality. Hole 700B, Northeast Georgia Rise, southwest Atlantic sector of the Southern Ocean.

\section{Corbisema recta (Schulz, 1928) Ling, 1972}

Remarks. Rare specimens were found only in Sample 114-698A12R-1, 40-42 cm, assigned to the lower portion of the foraminifer P4 Zone of the upper Paleocene.

Corbisema regina Bukry in Barron, Bukry, and Poore, 1984

Remarks. Bukry found Corbisema regina to be a common constituent of the middle Eocene Kellogg Shale of California. In the present study it was not found in the middle Eocene, possibly as a result of the poor preservation in Hole 702B. A couple of specimens were found in the lowermost silicoflagellate-bearing sample of Hole 703A (Sample 114-703A-18X-3, 94-96 cm), which is assigned to the Chiasmolithus oamaruensis Zone (NP18) and Zone P15 of the upper Eocene.

\section{Corbisema cf. regina \\ (Pl. 6, Figs. 5, 6)}

Remarks. The five specimens noted in Samples 114-700B-31R-2, 9-11 cm, and 114-700B-31R-3, 9-11 cm, are very similar to Corbisema regina that Bukry described from the middle Eocene Kellogg Shale of California. The specimens noted here more closely resemble those illustrated by Bukry with flattened struts and an expanded center rather than those with a central plate. Struts are clearly greater in width than the basal ring and have an apparent reticulate ornamentation. $C$. regina has not been previously described from the Paleocene, therefore, Corbisema cf. regina (noted here in the lowermost upper Paleocene in foraminifer Zone P3a) may represent an ancestral form of $C$. regina.

\section{Corbisema scapana $\mathrm{n} . \mathrm{sp}$.}

$$
\text { (PI. 6, Figs. 1-4) }
$$

Description. A robust, heavily silicified early Paleocene species. The basal ring is spade-shaped (scapana $=$ spade), consisting of two convex sides only slightly indented at the rod juncture and a third strongly indented side. The apical apparatus with three rods is moderately arched over the basal ring and slightly flattened in appearance. The juncture of the three apical rods is displaced toward the pointed end of the basal ring opposite the indented side, resulting in unequal division of the basal opening. Slight protuberances are usually present at the three corners of the basal ring. Thick basal accessory spines project inward in the abapical direction and have thick bifurcations at their ends that nearly touch bifurcations of the adjacent accessory spine.

Remarks. This species appears to be related to Corbisema falklandensis, which has its first rare occurrence just below Corbisema scapana. It is similar in the robustness of the skeleton and heavy, bifurcated accessory spines and may have evolved from $C$. falklandensis through reduction of the apical plate and change of basal ring shape from pear-shaped to spade-shaped.

Occurrence. It was found in the lowermost upper Paleocene Sample 114-700B-31R-4, 9-11 cm (62.36 Ma). The stratigraphic position of $C$. scapana is within lowermost Zone $\mathrm{P} 3 \mathrm{a}$ and within the Fasiculithus tympaniformis Zone.

Holotype. PMO 121,045 (Pl. 6, Figs. 3, 4).

Isotype. PMO 121,046 (PI. 6, Figs. 1, 2).

Type locality. Northeast Georgia Rise, southwest Atlantic sector of the Southern Ocean.

\section{Corbisema toxeuma Bukry, 1978b}

Remarks. Bukry (1978b) described this species from the lower Eocene Naviculopsis foliacea Zone of DSDP Hole 390A on the Blake Plateau, where it is associated with the Tribrachiatus orthostylus Zone. One possibly reworked specimen was found in the upper Eocene of Hole 703A; however, it is consistently present between Samples 114-700B-32R-2, 35-37 cm, and 114-700B-30R-4, 109-111 $\mathrm{cm}$. The range of the species in Hole $700 \mathrm{~B}$ is between foraminifer Zone P2 and lower Zone P4 of the upper lower to middle upper Paleocene. The species was not noted in the lower Eocene, as in Hole $390 \mathrm{~A}$; however, its absence in lower or middle Eocene sediments may be the result of poor preservation of this interval at the Leg 114 sites.

\section{Corbisema cf. toxeuma}

Remarks. A single specimen in Sample 114-700B-30R-3, 106-108 $\mathrm{cm}$, and within the range of the species it is attributed to, has accessory spines that are offset slightly from their normal position near the rod juncture with the ring.

\section{Corbisema triacantha (Ehrenberg, 1844) Bukry and Foster, 1973}

Remarks. Corbisema triacantha s. ampl. includes simple equilateral, symmetric forms of Corbisema having moderate-to-long spines and not otherwise attributed to other taxa in this study. Such forms were found in Holes 698A, 700B, 703A, and 702B.

\section{Corbisema triacantha convexa Bukry, 1978d}

Remarks. Present only in the lower Miocene of Hole 703A.

Corbisema triacantha lepidospinosa $\mathrm{n}$. subsp.

$$
\text { (Pl. 4, Figs. 9-14) }
$$

Description. The distinguishing characteristics of this subspecies are the small size of the basal apparatus and the long, slender radial spines. The basal ring is variable in proportions, being an equilateral 
or isosceles triangle; however, equilateral forms predominate. The three apical bars are moderately elevated above the basal ring and are joined together above the center or slightly off-center of the basal opening. Apical rods generally merge with the midpoint of the basal ring sides. It possesses long, gently tapering, elegant spines (lepidospinosa $=$ elegant spined). Radial spines are generally longer than the basal ring sides and very thin and fragile at their ends. One or more of the spines commonly is curved toward the end. It possesses small, tapering, and almost transparent basal accessory spines. In the youngest of the samples (114-700B-29R-CC), shorterspined forms occur with spines closer to the length of the basal ring sides but still exhibiting curved spine tips (Pl. 4, Fig. 14). These shorter-spined forms are tabulated separately in figures and tables as Corbisema triacantha lepidospinosa (short-spined morphotype).

Remarks. Corbisema triacantha triacantha s. ampl. is rare in previously described Paleocene sections and it is possible that $C$. triacantha lepidospinosa has been lumped into this group in previous studies.

Occurrence. C. triacantha lepidospinosa occurs in Samples 114700B-29R-CC through 114-700B-30R-3, 106-108 cm. It is extremely abundant in Sample 114-700B-30R-1, 99-101 cm, where it accounts for $55 \%$ of the assemblage. The range of the subspecies is within the calcareous nannofossil Heliolithus kleinpellii and Fasiculithus tympaniformis Zones, lower planktonic foraminifer Zone P4, and within Chron C26 of the upper Paleocene.

Size. Radial spine lengths are generally $18-30 \mu \mathrm{m}$ and basal ring sides are generally $19-24 \mu \mathrm{m}$.

Holotype. PMO 121,047 (PI. 4, Figs. 9, 10).

Isotypes. PMO 121,048 (PI. 4, Figs. 11-12), PMO 121,049 (PI. 4, Fig. 13), and PMO 121,050 (Pl. 4, Fig. 14).

Type locality. ODP Hole 700B, Northeast Georgia Rise, southwest Atlantic sector of the Southern Ocean.

\section{Corbisema triacantha mediana Bukry, 1978a}

Remarks. This species is distinguished from Corbisema triacantha triacantha by the distinctive asymmetric locations of the junctions of the struts to the basal ring (Bukry, 1978a). The species is common in the lower Miocene of Hole 703A and sporadic in older sediments of the same hole through the upper Eocene. Bukry (1978b) raised the question as to whether short-spined forms of Corbisema triacantha mediana should be combined with long-spined forms. In the present study, only a single short-spined form was noted in Sample 114-703A$17 \mathrm{X}-3,103-105 \mathrm{~cm}$.

\section{Corbisema xenica Bukry, 1978b}

Remarks. This rarely noted species was found in upper Eocene Samples 114-703A-15H-6, 40-42 cm (38.2 Ma), and 114-703A-17X-3, $103-105 \mathrm{~cm}(38.8 \mathrm{Ma})$, of Subchron C16N.

\section{Corbisema sp.}

$$
\text { (PI. 4, Fig. 19) }
$$

Remarks. The morphologic variability of this silicoflagellate needs further study before establishing its taxonomic status. It has an isosceles triangular basal ring divided into three lobes by slightly elevated apical rods. One lobe is distinctly larger than the other two, with parallel basal ring sides that merge through gentle curvature toward the radial spine. The other two pointed lobes are pointed toward the slender and short radial spines. Strong indentations occur to the basal ring where the lateral rods merge adjacent to the large lobe; the other stricture is minor. Accessory spines are small and very slender. Occurrences are within the lower to upper Paleocene of Hole $700 \mathrm{~B}$ between Samples 114-700B-32R-5, 40-42 cm, and 114-700B29R-CC (63.2-60.8 Ma).

\section{Corbisema sp. 2}

Remarks. No suitable photographs could be obtained at this time to illustrate this distinctive but small Corbisema that was noted in the Chiasmolithus oamaruensis Zone (NP18) of the upper Eocene of Hole $703 \mathrm{~A}$. The basal ring has three equilateral sides (each generally only 14 $\mu \mathrm{m}$ in length) and three slightly elongated sides, each joining at the midpoint of each side of the basal ring. One side of the basal ring is with smooth convex curvature, and the other sides are slightly indented at the bar-ring juncture. It possesses three radial spines 7-8 $\mu \mathrm{m}$ long.
Corbisema sp. 3

(Pl. 4, Fig. 18)

Corbisema hastata minor Bukry, 1978b, p. 815, pl. 1, fig. 9.

Remarks. Single occurrences of this very small Corbisema were noted in three samples in the upper Paleocene of Hole 700B. These specimens resemble specimens that Bukry (1978b) noted as having a lopsided basal ring and isosceles format.

\section{Corbisema sp. 4}

(PI. 2, Figs. 10, 11)

Remarks. This probable intraspecific variation of Corbisema constricta differs only by the presence of an extremely thin, threadlike apical bar. Rare specimens were found in Paleocene Sample 114700B-31R-2, 9-11 cm (62.1 Ma), which was assigned to the Fasiculithus tympaniformis Zone. A single occurrence was noted in Sample 114-698A-3R-1, 40-42 cm, of the Discoaster sublodoensis Zone and another single occurrence in Sample 114-702B-18X-2, 40-42 cm, also in the D. sublodoensis Zone.

\section{Genus DICTYOCHA Ehrenberg, 1839}

\section{Dictyocha acuta Bukry, 1987}

Remarks. This recently described species has been noted from the western North Atlantic and California from the upper Eocene. Herein, it occurs in the upper Eocene of Hole 703A. Only its last occurrence was noted just above the base of the nannofossil Isthmolithus recurvus Zone and within Subchron C16N. The species' first occurrence is $39.24 \mathrm{Ma}$ (Subchron C16N/C16R boundary).

\section{Dictyocha alta Ciesielski in Shaw and Ciesielski, 1983}

Remarks. The only previously noted occurrence of the species is from the lower Oligocene of Site 513 in the southeast Argentine Basin. In this study a single specimen was noted in the lower Oligocene of Hole $703 \mathrm{~A}$ within Subchron C11R.

\section{Dictyocha cf. alta}

Remarks. The compared specimens are from the upper middle Eocene (Subchrons C19R-C20N) of Hole 702B, where they are found within foraminifer Zones P12/13 and the calcareous nannofossil Nannotetrina fulgens Zone. Specimens differ by the straighter sides of the rhombic basal ring but have the characteristic highly elevated apical apparatus.

\section{Dictyocha aspera martinii Bukry, 1975a}

$$
\text { (PI. 7, Figs. 19-23) }
$$

Remarks. This species was found between Samples 114-703A-17X-3, $103-105 \mathrm{~cm}$, and $114-703 \mathrm{~A}-11 \mathrm{H}-6,90-92 \mathrm{~cm}$. Its range in this hole is from the upper Eocene to lower Oligocene. Its last occurrence occurs at a hiatus within Subchron C12R to near the C12N/C12R boundary and it ranges at least as low as upper Eocene foraminifer Zone P15.

Dictyocha bryonalis Bukry in Barron, Bukry, and Poore, 1984

Remarks. Occurrences of this species are rare; however, they give further insight as to its geologic range. It occurs in Holes $703 \mathrm{~A}$ and $702 \mathrm{~B}$ between the lower middle Eocene and basal Oligocene. Its first noted occurrence is in Subchron C21N within the foraminifer Zone $\mathrm{P} 10$ and the calcareous nannofossil Discoaster sublodoensis Zone. This latter datum is at a hiatus, however, within Chron C13. The last occurrence was found in foraminifer Zone P18/20 and the Reticulofenestra oamaruensis Subzone of the calcareous nannofossil Isthmolithus recurvus Zone.

\section{Dictyocha cf. byronalis}

$$
\text { (PI. 7, Figs. 5, 6) }
$$

Remarks. The figured specimen comes from the middle Eocene of Hole $702 \mathrm{~B}$ and is similar to Dictyocha byronalis, except for the smaller internal diameter of the ring $(16 \mu \mathrm{m})$ and the longer, more slender major axis spines.

\section{Dictyocha challengeri Martini and Müller, 1976}

Remarks. A single specimen of this rarely noted species was observed in the upper middle Eocene of Hole 702B within foraminifer Zone P12/13 and Subchron C13R. 
Dictyocha deflandrei completa (Glezer, 1966) Bukry, 1978c (Pl. 7, Figs. 15, 16)

Remarks. Bukry (1978c) noted that this subspecies has a smaller apical plate that is thicker and less consistently square in outline than other subspecies. Specimens assigned to this subspecies are similar to that figured here, although there is some variation in the overall size of the specimens. It differs from Dictyocha deflandrei by the lack of termination of the rod canals in the apical structure and it has a small apical plate with concave sides. Many specimens exhibit a greatly reduced plate, which is hardly more than a slight widening of the rods at their apical juncture. There is no apparent difference in the range of this subspecies with respect to Dictyocha deflandrei deflandrei in Leg 114 sediments, in that the rare single occurrence of the latter species in the middle Eocene is reworked. The stratigraphic utility of taxonomic separation of the two subspecies is, therefore, in question.

\section{Dictyocha deflandrei deflandrei Frenguelli (1940) ex. Glezer, 1966}

$$
\text { (Pl. 7, Figs. 10-12) }
$$

Remarks. Dictyocha deflandrei deflandrei is characterized by a square apical plate and apical rod canals that terminate at the corners of the apical plate. These terminating rod canals are clearly evident in the Leg 114 samples and are the most useful discriminating morphologic feature separating it from other related taxa. Other than the two specimens found in the lower middle Eocene of Hole 702B, its occurrence is limited to the upper Eocene-lower Oligocene of Hole 703. Its range in this latter hole is within foraminifer Zones P15 to P18/20 and calcareous nannofossil Chiasmolithus oamaruensis to Chiasmolithus altus Zones. According to the paleomagnetic record of Hole $699 \mathrm{~A}$ this datum occurs within Subchrons C11R to C12N (32.06-32.90 Ma).

This subspecies shows considerable variability, including forms with straight-sided apical rings, slightly scalloped basal rings (Pl. 7, Figs. 10, 11), basal rings with slightly convex sides (Pl. 7, Fig. 12), distinct apical plates ( $\mathrm{Pl}$. 7, Figs. 10-12), and some reduced apical plates. The ranges of all these morphotypes are identical in Hole $703 \mathrm{~A}$. Therefore, these should be considered variations of the same subspecies and warrant no further taxonomic splitting.

$$
\text { Dictyocha deflandrei furtivia } \mathrm{n} \text {. subsp. }
$$$$
\text { (PI. 7, Figs. 13, 14) }
$$

Description. Dictyocha deflandrei furtivia possesses a square, straight-sided basal ring with radial spines and a length generally close to the length of the basal ring sides. Lateral rods are symmetrically disposed and raise the apical apparatus. The lateral rods have a flattened lamellar appearance and narrow canals that terminate where the rods widen slightly vertically from the basal ring a short distance before turning to form the merging that forms the apical plate. The apical plate is elongated in the direction of one set of radial spines. All four sides of the apical plate are strongly curved because of the close proximity of the lateral rods.

Remarks. This is the first noted occurrence of a subspecies of Dictyocha deflandrei in the Paleocene. The oldest previous occurrence of a subspecies is from the Eocene. D. deflandrei furtivia is similar to Dictyocha deflandrei deflandrei in respect to the presence of a square basal ring and lateral rod canals that terminate in an apical plate. It differs from the latter species by possessing a smaller apical plate rather than a large, thin, square, apical plate. Other subspecies of $D$. deflandre $i$ have younger ranges and lack lateral rod terminations in the apical structure.

Occurrence. The species range in Hole 700B extends from upper Zone P2 to within Zone P4 and near the base of Zone NP8. This species and Dictyocha precarentis are the oldest representatives of the genus found within the lower Paleocene. Its first occurrence is lower Chron C26 and its last occurrence slightly above the Chron C25/C26 boundary ( $60.21 \mathrm{Ma})$.

Holotype. PMO 121,051 (Pl. 7, Figs. 13, 14).

Type locality. Hole 700B from the Northeast Georgia Rise, southwest Atlantic sector of the Southern Ocean.

\section{Dictyocha deflandrei sp. 1}

$$
\text { (PI. 7, Figs. 17, 18) }
$$

Remarks. A single specimen found near the Miocene/Oligocene boundary (Subchron $\mathrm{C} 6 \mathrm{CN}$ ) of Hole $703 \mathrm{~A}$ is not attributable to any described species of Dictyocha deflandrei but bears similarity to Dictyocha deflandrei lobata (Bukry, 1978c) and Dictyocha frenguellii var. carentis $\mathrm{f}$. carentis (Glezer, 1966). The figured specimen has a similarly shaped but large apical plate to that of Dictyocha deflandrei lobata. It is also similar as to size and basal ring, but has an asymmetrical strut arrangement. The size and shape of the apical plate and other features are similar to $D$, frenguellii var. carentis $\mathrm{f}$. carentis (Glezer, 1966, pl. 11, figs. 8, 10-13); however, the apical plate is not as highly elevated. The specimen may be a new species, although it is most certainly reworked in Hole 703A, as D. deflandrei became extinct globally earlier in the Oligocene.

\section{Dictyocha elata var. media Glezer, 1964}

Dictyocha elata var. media Glezer, 1964, p. 51, pl. 1, fig. 8.

Remarks. A single specimen was found in Sample 114-703A-16X1, 44-46 cm, of the upper Eocene. Originally described from the upper Eocene of the Soviet Union, this and other very small species have probably been largely overlooked in previous studies because of their small size.

\section{Dictyocha aff. elongata Glezer, 1960}

$$
\text { (Pl. 4, Fig. 15) }
$$

Remarks. The figured specimen bears a strong resemblance to Dictyocha elongata, which was noted by Glezer (1966) from the lower and ?middle Eocene of the Soviet Union. Herein it was noted only from Sample 114-700B-30R-2, 118-120 cm, within lower foraminifer Zone P4 of the upper Paleocene.

\section{Dictyocha fibula fornicata Bukry, 1975a}

Dictyocha grandis Ciesielski and Shaw in Shaw and Ciesielski, 1983 (Pl. 5, Fig. 6)

Remarks. Dictyocha grandis has been previously recognized in DSDP Hole 512, also from the South Atlantic sector of the Southern Ocean. Preservation of the species in most samples from Hole 702B is poor, in comparison with that at the type locality, with numerous fragments of this very large and distinctive silicoflagellate. Shaw and Ciesielski (1983) illustrated a great deal of intraspecific variability in this species. In the present study two morphotypes of $D$. grandis are listed separately in the figures and tables. This was also done by Shaw and Ciesielski (1983) to aid future investigators in determining possible distinct stratigraphic ranges of various morphotypes that may merit the creation of subspecies. Discussion of two of these morphotypes follows.

Occurrence. The middle Eocene type section of Hole 512 is bracketed by unconformities resulting in some uncertainty as to the age of the stratigraphic range of $D$. grandis. The first and last occurrences of the species at this site are at unconformities; however, Shaw and Ciesielski (1983) interpreted the paleomagnetic record of the Hole 512 middle Eocene section to represent Subchrons C18N through C19R ( $\sim 1.29-44.30 \mathrm{Ma}$, ages corrected to Berggren et al., 1985).

In Hole 702B, D. grandis was found between Samples 114-702B$5 \mathrm{X}-\mathrm{CC}$ and 114-702B-10X-3, 140-142 cm. Based upon shipboard examination of core-catcher samples, Ling (in Ciesielski, Kristoffersen, et al., 1988) found additional specimens in Sample 114-702B$10 \mathrm{X}-\mathrm{CC}$, its lowermost occurrence. The species interval of occurrence in Hole 702 is within foraminifer Zones P15 (lowermost) through P12/13 and the calcareous nannofossil Chiasmolithus solitus Zone (NP16) and possibly the uppermost Nannotetrina fulgens Zone (NP15-16) and lowermost Chiasmolithus oamaruensis Zone (the Discoaster saipanensis Zone was unrecognized in Hole 702B). The FAD of $D$. grandis is in Subchron C19R (44.1 Ma) and the LAD of the species occurs below the Subchron C16N/C16R boundary (39.24 Ma) in Hole 703A and above the FAD of C. oamaruensis $(39.8 \mathrm{Ma}$ ) in Holes $703 \mathrm{~A}$ and $702 \mathrm{~B}$ (within Subchron C16R to uppermost $\mathrm{C} 17 \mathrm{~N})$.

Dictyocha grandis Ciesielski and Shaw in Shaw and Ciesielski, 1983 (with two apical windows)

Remarks. A single specimen of a morphotype with two apical windows was noted in Sample 114-702B-8X-3, 40-42 cm. No such morphotype was noted by Shaw and Ciesielski (1983) in Hole 512. 
Dictyocha grandis Ciesielski and Shaw in Shaw and Ciesielski, 1983 (pentagonal basal ring)

Dictyocha grandis var. B Shaw and Ciesielski, 1983, p. 711, pl. 9, fig. 4.

Remarks. Although pentagonal morphotypes are rare, the limited data from Holes 512 and 702B suggest it may be limited to the upper portion of the range of the species.

\section{Dictyocha hexacantha Schulz, 1928}

$$
\text { (PI. 7, Fig. 3) }
$$

Remarks. Shaw and Ciesielski (1983) noted that the occurrence of this species is rare at high latitudes. Although used as a zonal indicator in lower latitude sections, Dictyocha hexacantha was found in only three samples from Hole 703A within the calcareous nannofossil Chiasmolithus oamaruensis Zone and lower Isthmolithus recurvus Zone.

\section{Dictyocha hexacantha?}

(Pl. 7, Figs. 1, 2)

Remarks. An exceptional large specimen found in Sample 114703A-18X-3, 94-96 cm (Subchron C16R), has the skeletal design of Dictyocha hexacantha but is heavily silicified with surface ornamentation similar to that of Corbisema disymmetrica.

Dictyocha pentagona (Schulz, 1928) Bukry and Foster, 1973

Dictyocha precarentis Bukry, 1976a

(PI. 7, Figs. 4, 8, 9)

Remarks. The entire geologic range of the species is represented in Hole $700 \mathrm{~B}$, where its first occurrence was found in the middle of foraminifer Zone P2 and in lower Subchron C26R (62.7 Ma). The last occurrence of the species is within P4 and near the Subchron C25N/C25R boundary $(59.2 \mathrm{Ma})$. The greatest abundance of the species occurs within P4. Dictyocha precarentis was also noted in Hole 698A

\section{Dictyocha cf. quadralta Hanna, 1928}

(Pl. 5, Figs. 9, 10)

Remarks. The figured specimen is similar to the Late Cretaceous holotype of Hanna (1928), but possesses only two short spines, with the other two spines broken off or absent. A few such specimens were noted in Paleocene Samples 114-700B-30R-5, 111-113 cm, and 114700B-31R-6, 36-38 cm.

\section{Dictyocha quadria (Mandra, 1969) Martini and Müller, 1976}

$$
\text { (Pl. 5, Figs. 5, 8, 11) }
$$

Remarks. Rare occurrences of Dictyocha quadria were found consistently between Samples 114-703A-15H-6, 40-42 cm, and 114703A-18X-3, 94-96 cm (Chron C16). These occurrences are associated with the Isthmolithus recurvus Subzone of the Isthmolithus recurvus Zone, Chiasmolithus oamaruensis Zone, and Zones P16/17 through P15.

Listed separately in Table 7 and Figure 8 is a separate morphotype of D. quadria (with cylindrical spines). Previously, Martini and Müller (1976) noted a variety of characteristics to the corners of the basal ring, including spherical protuberances and rounded, flattened, and inflated corners. Forms otherwise similar to $D$. quadria, but with cylindrical spines, range concurrently with morphotypes with spherical protuberances in Hole 703A. These specimens are considered to be yet another intraspecific variation of $D$. quadria.

\section{Dictyocha aff. quadria}

$$
\text { (Pl. 5, Fig. 7) }
$$

Remarks. The figured specimen was the only one of its kind and was encountered in Sample 114-702B-8X-3, 40-42 cm. It occurs in the upper middle Eocene foraminifer P14 Zone and calcareous nannofossil Chiasmolithus solitus Zone, where it is slightly older than the portion of Hole 703A bearing Dictyocha quadria. The figured specimen occurs within the known range of $D$. quadria and is similar to the morphotype with cylindrical spines previously discussed. Its only significant difference is the slight scalloping of the sides of the basal ring, which is not characteristic of $D$. quadria. Nevertheless, this specimen is considered to be an intraspecific variant of this highly variable species.

\section{Dictyocha spinosa (Deflandre, 1950) Glezer, 1966}

Remarks. Dictyocha spinosa is another lower latitude index species that is rarely noted in high-latitude sequences. Only a couple of rare occurrences of the species were noted in the upper Eocene and lower Oligocene of Hole 703A.

\section{Dictyocha stelliformis Shaw and Ciesielski, 1983}

(PI. 5, Figs. 1-3)

Remarks. Common to abundant, whole and fragmented Dictyocha stelliformis were encountered in the middle Eocene of Hole 702B. The first occurrence of the species is abrupt in Sample 114-702B-10X-3, $140-142 \mathrm{~cm}$, where it accounts for most of the assemblage, which has been subjected to partial dissolution. Its first occurrence (44.07-44.21 $\mathrm{Ma}$ ) is directly correlated to near or slightly below the Subchron C19N/C19R boundary (44.06 Ma). The last occurrence of the species was noted in Subchron C18R (43.5-43.3 Ma).

Dictyocha stelliformis (pentagonal basal ring) Shaw and Ciesielski, 1983

(Pl. 5, Fig. 4)

Dictyocha stelliformis Shaw and Ciesielski, 1983, p. 712, pl. 6, fig. 5 .

Remarks. Ten specimens of this five-sided form were found in Sample 114-702B-10X-1, 140-142 cm (43.5 Ma), and another, probably reworked, specimen was found in Sample 114-702B-8X-3, 40-42 cm.

\section{Dictyocha torta Martini and Müller, 1976}

$$
\text { (Pl. 7, Fig. 7) }
$$

Remarks. Rare occurrences of the species were noted in the upper Eocene of Hole 703A. Martini and Müller in their study of Leg 38 Norwegian Sea sites found Dictyocha torta in the Corbisema bimucronata Zone at Site 340 and in the Dictyocha quadria Zone at Site 338. The species thus appears to have a range restricted to the late Eocene.

\section{Dictyocha sp. 1}

Remarks. The four specimens found in Samples 114-700B-28R-2, $116-118 \mathrm{~cm}$, and $114-700 \mathrm{~B}-28 \mathrm{R}-4,116-118 \mathrm{~cm}$, probably represent a new species and will await formal description at a later date when suitable micrographs are available. This form of Dictyocha is characterized by a basal ring with four equal sides that have a strong and evenly concave indention on each side at the apical rod-basal ring juncture. Four lateral rods and an apical bar of approximately equal lengths divide the basal ring opening. Apical elements are thin and lamellar in nature. Basal ring spines are moderate to long and of equal length. The occurrence is limited to the upper Paleocene Heliolithus riedellii Zone and foraminifer $\mathrm{P} 4 \mathrm{Z}$ Zone.

\section{Dictyocha sp. 3}

(Pl. 6, Figs. 18, 19)

Remarks. This large Dictyocha was found only in the poorly preserved middle Eocene of Hole 702B. It has a nearly square basal ring, $\sim 75-80 \mu \mathrm{m}$ long per side. The basal ring is robust and has a rod thickness of $\sim 3.5-4.0 \mu \mathrm{m}$. Basal spines are generally $14-16 \mu \mathrm{m}$ and taper only slightly. Basal accesory spines are offset significantly from the strut juncture with the basal ring. The apical apparatus is elevated with a short apical bar of $7-10 \mu \mathrm{m}$ and four lateral rods, which commonly do not merge with the center of the basal ring sides. One or more basal ring sides are bowed out at the rod juncture with the basal ring.

\section{Dictyocha sp. (asperoid)}

Dictyocha sp. (asperoid) Bukry, 1987, pl. 7, fig. 10.

Remarks. It occurs throughout the upper Eocene to lowermost Oligocene of Hole $703 \mathrm{~A}$ and is similar to the figured specimen by Bukry (1987) from the middle Eocene of Site 612 from the northwestern North Atlantic.

\section{Genus DISTEPHANUS Stohr, 1880}

Distephanus antarcticus (Ciesielski, 1975) n. comb.

Cannopilus antarcticus Ciesielski, 1975, p. 654, pl. 1, figs. 1-9. 
Remarks. The author follows the practice of Bukry and Monechi (1985) of not recognizing the genus Cannopilus and includes all phenotypic varieties with nonglobular and subdivided apical apparatus in Distephanus. Six specimens of this species, endemic to the Southern Ocean, were noted in lower Miocene Sample 114-703A-3H$2,40-42 \mathrm{~cm}$.

\section{Distephanus boliviensis (Frenguelli, 1940) Bukry, 1973}

Remarks. Bukry (1979) designated a lectotype from Frenguelli's (1940) type suite as Distephanus boliviensis boliviensis, which has relatively short equant spines and a single apical ring; it is particularly common in the Pliocene and lower Quaternary. Spine length was not observed as a stable phenotype within the Distephanus boliviensis and Distephanus speculum stock. Herein all specimens are tabulated as $D$. boliviensis, regardless of spine length, as long as the basal spine lengths are equal.

Distephanus boliviensis (hemisphaericoid)

Distephanus boliviensis (hemisphaericoid) Ciesielski (unpubl. data).

Remarks. Similar in all respects to Distephanus boliviensis (cannopilean) of Ciesielski, Kristoffersen, et al. (1988) except that the multiwindowed apical apparatus is almost as wide as the basal ring. In contrast, D. boliviensis (cannopilean) has a multiwindowed apical apparatus that is distinctly less than the width of the basal ring. It differs from Distephanus speculum hemisphaericus by its equal basal spine length.

\section{Distephanus crux s.1.}

Remarks. Distephanus crux is herein regarded as a group of subspecific taxa generally characterized by a tetragonal basal ring surmounted by an apical ring. Several subspecies are tabulated separately, which conforms to existing subspecies definitions. Other variants are tabulated as Distephanus crux s.l.

Distephanus crux darwinii Bukry, 1976a

Distephanus crux loeblichii Bukry, 1978 b

Distephanus crux parvus Bukry, 1982

Distephanus crux scutulatus Bukry, 1982

\section{Distephanus crux var. 1}

Remarks. This variety is characterized by its small size and highly elevated apical ring.

\section{Distephanus crux var. 2}

Remarks. This rare but distinctive morphotype of Distephanus crux was encountered in Hole 703A and will be described formally in a later publication. It has very fragile and thin skeletal components. The basal ring is rhombic, with each side $\sim 16 \mu \mathrm{m}$. A small square apical window, $\sim 6 \mu \mathrm{m} / \mathrm{side}$, is symmetrically connected by struts to the basal ring. Major axis radial spines are $\sim 35 \mu \mathrm{m}$ and minor axis spines are $\sim 10 \mu \mathrm{m}$.

\section{Distephanus hannai (Bukry, 1975b) Bukry, 1979}

Distephanus quinquangellus Bukry et Foster, 1973

\section{Distephanus raupii Bukry, 1976a}

Remarks. The base of the species range in Hole 703A is above a hiatus separating Subchrons C9R and C11N. In Hole 699A its FAD is recorded within Subchron C11N (31.38 Ma; P. F. Ciesielski, unpubl. data). The last occurrence is within uppermost Subchron C6N (23.3 Ma) to lowermost C6BR (22.9 Ma) in Hole 703A. The last occurrence of the species was not observed in Hole 699A as a result of a disconformity that eliminated the uppermost portion of its range. Ranging concurrently with Distephanus raupii is an otherwise identical morphotype, except that the strut-basal ring junctures are not offset with respect to the midpoint of each basal ring side. This morphotype is compared with $D$. raupii as Distephanus cf. raupii because of its similar geologic range in Hole 703A. Reference to the abundance of $D$. raupii and $D$. cf. raupii in Table 7 and Figure 9 reveals that the asymmetric strut arrangement of $D$. raupii may have developed later in the range of this species. A single specimen of $D$. raupii with three apical windows was encountered in Sample 114-703A-7H-2, 110-112 cm.

Distephanus schauinslandii Lemmermann, 1901

Remarks. This species was recorded only in Sample 114-703A-5H$4,42-44 \mathrm{~cm}$.

Distephanus speculum binoculus (Ehrenberg) Bukry, 1975b

Distephanus speculum hemisphaericus (Ehrenberg, 1844) Bukry $1975 \mathrm{~b}$ emend. Ciesielski (unpubl. data)

Remarks. Recent detailed quantitative analyses of silicoflagellates with multiple-windowed apical structures by Shaw and Ciesielski (1983) and Ciesielski (unpubl. data) reveal justification for emendation of this species. This taxon is emended to include forms with a six- to eight-sided basal ring similar to but slightly larger in size than Distephanus speculum speculum. It is, however, distinctly smaller than Distephanus boliviensis, with a relatively flat to slightly domed apical apparatus. It bears four or more apical windows, which have a width almost as wide as the basal apparatus. Supporting rods connecting the apical apparatus to the basal ring are indistinct because of the width of the apical apparatus. Apical windows may be arranged in any fashion, as there is no stratigraphic significance to particular arrangements. Apical windows may be irregularly arranged and sized. Basal accessory spines are usually present on the basal ring. This species is present only in Hole 703A.

\section{Distephanus speculum patulus Bukry, 1982}

Distephanus speculum pentagonus Lemmermann, 1901

Distephanus speculum pentagonus Bukry, 1978c, p. 785, pl. 2, fig. 11.

Remarks. Specimens tabulated as Distephanus speculum pentagonus are moderate in size and have large to moderate apical rings with angular corners. They are also lacking in basal accessory spines, which differentiates them from smaller Neogene species. A single occurrence was noted in the middle Eocene of Hole 702B, with sporadic occurrences primarily throughout the upper EoceneOligocene of Hole 703A. A single specimen with four apical windows was noted in Sample 114-703A-10H-3, 0-2 cm, of the lower Oligocene.

Distephanus speculum speculum s.l. (Ehrenberg, 1839) Haeckel, 1887

Distephanus speculum triommata (Ehrenberg) Bukry, 1981

Distephanus speculum var. 1

Remarks. This morphotype is similar to Distephanus speculum but is larger with pronounced spines on the apical ring.

Distephanus stradneri (Jerkovic, 1965) Bukry, 1978a

Genus LYRAMULA Hanna, 1928

Lyramula furcula Hanna, 1928

Remarks. A single reworked occurrence of this Cretaceous species was noted in the middle Eocene of Hole 702B.

Lyramula minor (Deflandre, 1940) Deflandre, 1950

Remarks. A single reworked occurrence of this Cretaceous species was noted in the upper Paleocene of Hole 700B.

\section{Genus NAVICULOPSIS Frenguelli, 1940}

Naviculopsis biapiculata biapiculata (Lemmermann, 1901) Frenguelli, 1940 (PI. 10, Figs. 8, 9)

Remarks. This species is rare in the middle Eocene of Hole 702B and rare to abundant in the uppermost Eocene-Oligocene of Hole $703 \mathrm{~A}$. Specimens displaying a particularly highly arched apical bar (PI. 10, Figs. 8, 9) are abundant in Sample 114-703A-7H-5, 110-112 
$\mathrm{cm}$. The last consistent and common occurrence of this species in Hole $703 \mathrm{~A}$ is in Subchron C6CN between 24.0 and $23.5 \mathrm{Ma}$. Naviculopsis eobiapiculata and Naviculopsis biapiculata biapiculata together are a sizable proportion of the late Oligocene assemblage in Hole $703 \mathrm{~A}$, comprising up to more than $50 \%$ of the assemblage.

\section{Naviculopsis biapiculata nodulifera $\mathrm{n}$. subsp.} (Pl. 10, Figs. 6, 7)

Description. Similar to Naviculopsis biapiculata biapiculata except for the presence of a distinct small node centrally located on the slightly flattened apical bar. The apical node is clearly visible in oblique view or apical view with a focus on the plane of the apical bar. The apical bar has a prominent upward arch. Axial spine lengths are more or less equal to the body ring length. Basal ring length-to-width ratios average 1.6-1.7.

Remarks. It is distinguished from all other Naviculopsis taxa by the presence of the small node centrally located on the apical bar.

Occurrence. Naviculopsis biapiculata nodulifera occurs in the lower Oligocene of Hole $703 \mathrm{~A}$ in association with $N$. biapiculata biapiculata. Its last occurrence is in the lower upper Oligocene between upper Subchron C8N and C7R. Its first occurrence is in Sample 114-703A-12H-7, 2-4 cm, within foraminifer Zone P18/P20 and immediately above a hiatus that has removed a portion of Subchron C13R and possibly a portion of C13N (P. F. Ciesielski, unpubl. data).

Holotype. PMO 121,052 (Pl. 10, Figs. 6, 7).

Type locality. Hole 703A from the Meteor Rise, southeast Atlantic sector of the Southern Ocean.

\section{Naviculopsis biapiculata var. 1}

$$
\text { (Pl. 9, Fig. 22) }
$$

Remarks. Concurrently ranging with Naviculopsis biapiculata biapiculata (with the highly arched apical bar) are morphotypes that have a wider apical ring, are generally smaller, and have an apical bar with a slightly reduced arch. Length-to-width ratios of this variety are between 1.4 and 1.75 . This ratio is significantly less than the $2.1-3.0$ ratio of Oligocene specimens of Naviculopsis eobiapiculata. Typical specimens of the wider type, such as the one figured, have spine lengths of $16 \mu \mathrm{m}$, a basal ring length of $20 \mu \mathrm{m}$, and a basal ring width of $14 \mu \mathrm{m}$.

Naviculopsis constricta (Schulz, 1928) Bukry emend., in Barron, Bukry, and Poore, 1984

Remarks. Naviculopsis constricta occurs in all four of the studied Paleogene sections of Holes 698A, 700B, 702B, and 703A. The first and last occurrences of the species are documented in Holes $700 \mathrm{~B}$ and $703 \mathrm{~A}$, respectively. The first occurrence is in Sample 114-700B-29R-2, 37-38 cm, within the lower foraminifer P4 Zone and Heliolithus riedellii Zone. The paleomagnetic record of this site places the datum in Subchron $\mathrm{C} 26 \mathrm{~N}$ of the early late Paleocene. The last consistent but rare occurrence of $N$. constricta occurs in Sample 114-703A-11H-2, 90-92 cm, although two reworked rare occurrences appear higher. Bracketing samples for this datum are just above or below the Subchron C12N/C11R boundary in Hole 703A. The last occurrence of the species as $10 \%$ or more of the assemblage is in Sample 114-703A-15H-2, 40-42 cm, only $40 \mathrm{~cm}$ above the Chron $\mathrm{C} 13 / \mathrm{C} 15$ boundary $(37.24 \mathrm{Ma})$. This abundance drop prior to its disappearance may occur slightly higher in the disturbed interval of Core 114-703A-14H; however, it must still be no younger than Subchron C13R. Because $N$. constricta is such a dominant constituent of the upper Eocene, its major and sudden drop in abundance near the Eocene/Oligocene boundary is a much more reliable stratigraphic marker than its rare last occurrence, which is in the lower Oligocene.

Both large and small forms of $N$. constricta co-occur, as noted by Bukry (in Barron et al., 1984). The apical band width appears to be the most stable feature, at generally 6 to $7 \mu \mathrm{m}$. The overall length between spine tips ranges from 220 to $80 \mu \mathrm{m}$, body length from 65 to $25 \mu \mathrm{m}$, body width from 16 to $12 \mu \mathrm{m}$, and spine length from 98 to $27 \mu \mathrm{m}$.

A single figured specimen (PI. 9, Fig. 21) with an obliquely oriented apical band was found in middle Eocene Sample 114-702B-9X-1, $118-120 \mathrm{~cm}$, and is compared to $N$. constricta.
Naviculopsis cruciata $\mathrm{n}$. sp.

(Pl. 9, Figs. 1-4, 5?)

Description. This small silicoflagellate has an oval ring with the long axis of the ring aligned with the spines. The length-to-width ratio of the basal ring is 1.4-1.7. An elevated apical apparatus is centered above the basal ring, consisting of four slightly flattened rods, aligned with the major and minor axes, and generally steeply turned down toward the basal ring. Apical rods generally are not merged together but merge instead into a short central rod, which is oriented obliquely to the major axis, giving the rods an offset appearance. Axial spines are 1.4 to 1.8 times longer than the major axis length of the basal ring. Both spines are commonly canted slightly to one side of the major axis.

Remarks. Naviculopsis cruciata is directly descended from Naviculopsis primativa, the oldest known Naviculopsis. Both species are abundant but have short geologic ranges, preceding the earliest occurrence of Naviculopsis constricta. Because of the abundance of the species and its position as the second oldest known Naviculopsis, it is described here as a new species. $N$. cruciata and $N$. primativa flourished only briefly, but probably gave rise to the other members of the genus, which came to dominate late Paleocene to late Eocene assemblages of the Southern Ocean.

Occurrence. $N$. cruciata occurs only in Sample 114-700B-30R-1, $99-101 \mathrm{~cm}$, where it comprises $10 \%$ of the assemblage. This sample is assigned to the lower portion of planktonic foraminifer Zone P4 (Nocchi et al., this volume) and is near the boundary between the calcareous nannofossil Fasiculithus tympaniformis Zone (Sample 114-700B-30R-2, 120-121 cm) and Heliolithus kleinpellii Zone (Sample 114-700B-29R-CC), as noted by Crux (this volume). The age of the occurrence of this species is $61.4 \mathrm{Ma}$ and within paleomagnetic Subchron C26R.

Holotype. PMO 121,053 (PI. 9, Figs. 3, 4).

Isotype. PMO 121,054 (Pl. 9, Figs. 1, 2).

Type locality. Northeast Georgia Rise, southwest Atlantic sector of the Southern Ocean.

Naviculopsis danica Perch-Nielsen, 1976b

Remarks. A single specimen was noted in Sample 114-703A-12H$3,2-4 \mathrm{~cm}$, within the lower Oligocene calcareous nannofossil Reticulofenestra daviesii Zone.

\section{Naviculopsis eobiapiculata Bukry, 1978c}

(Pl. 9, Figs. 17, 18; Pl. 10, Figs. 4, 5)

Remarks. In the uppermost Eocene, Naviculopsis eobiapiculata was found to be much larger than the older specimens. It obtains a length between spine tips of up to $120 \mu \mathrm{m}$. It has a length-to-width ratio of the basal ring from 2.3 to 3.0 , very similar to the $2.1-3.0$ ratio cited by Bukry (1978c) from measured Oligocene specimens. Spine lengths are generally about $90 \%$ of the length of the basal ring. The apical bar is arched less than Naviculopsis biapiculata with some slightly flattened and a sporadic slight constriction where the apical bar meets the basal ring. The observed specimens most closely resemble the holotype (pl. 4, fig. 9) and an isotype (pl. 4, fig. 16) of Bukry (1978c).

\section{Naviculopsis eobiapiculata var. 1}

Remarks. Few specimens were noted in the upper Paleocene of Hole $700 \mathrm{~B}$, but it is common in the lower Eocene of Hole 698A. It is also common in the upper Eocene of Hole 703A, but not very abundant in the lower Oligocene, where it last appears. Most of those observed from the Paleocene have an axial spine to basal ring length ratio of $4: 3$. Bukry (1978c) cited the axial spines as typically greater than one-half as long as the basal ring.

Naviculopsis foliacea Deflandre, 1950

\section{Naviculopsis lata (Deflandre, 1932) Bukry, 1982}

$$
\text { (Pl. 10, Fig. 10) }
$$

Remarks. The species is absent in all Leg 114 Paleogene sections. The sole occurrence was within Subchron C6CN to the upper lower Miocene of Hole 703A, between Samples 114-703A-5H-4, 42-44 cm, and $114-703 \mathrm{~A}-3 \mathrm{H}-5,40-42 \mathrm{~cm}$. 
Naviculopsis navicula (Ehrenberg, 1840) Deflandre, 1950

Remarks. Only a single specimen was noted in Sample 114-703A$4 \mathrm{H}-3,40-42 \mathrm{~cm}(22.8 \mathrm{Ma})$.

\section{Naviculopsis nordica hyalina Bukry, 1976b}

Remarks. One specimen found in Sample 114-702B-9X-3, 118-120 $\mathrm{cm}$ (43.1 Ma), from the middle Eocene has a significantly shorter basal ring length than the type specimens of Bukry (1976b). A second specimen from this same sample (PI. 9, Fig. 19) is attributed to this species but is extremely small, only $25 \mu \mathrm{m}$ between axial spine tips.

\section{Naviculopsis pandalata $\mathrm{n} . \mathrm{sp}$.}

$$
\text { (Pl. 9, Figs. 11-16) }
$$

Description. Naviculopsis pandalata is the largest representative of the genus encountered in the Paleogene sediments of Leg 114. The most diagnostic characteristic of this species is the twisted nature of the basal ring, which is readily recognized in oblique view (PI. 9, Figs. 11-13). The twist to the basal ring provides a distortion to the portals when viewed from the apical or abapical directions and unequal focal planes to opposite sides of the basal ring. The basal ring is long with subparallel sides, rounded ends, and a slight constriction at the juncture with the apical band. The ratio of ring length to maximum width is approximately $4: 1$. The basal ring becomes more laminar at about half the distance between the ring end and apical band. This transition to the apical band is accompanied by a turn of the ring laminae to a vertical orientation, where it expands into the apical band. The turning of the ring laminae creates a thinned appearance to the basal ring near the juncture with the apical band in an apical or abapical view. The apical band width is equal to or slightly less than the width of the basal ring at the band location. Axial spines vary in length from slightly longer to slightly shorter than the basal ring length. Spines appear to be flattened with a distinct tube that commonly gives the impression of a ridge in light microscopy.

Remarks. The only concurrently ranging species with similarity to N. pandalata are Naviculopsis constricta and Naviculopsis foliacea. It differs from both species by the prominent twist of the basal ring and greater size. The apical band width is significantly less than that of $N$. foliacea.

Occurrence. $N$. pandalata has a geologic range restricted to the upper Eocene, as noted in Holes 703A and 702B. In Hole 703A, it occurs more commonly in Samples 114-703A-17X-1, 105-107 cm (20\%), and 114-703A-18X-3, 94-96 cm. It also occurs in the other samples of the zone bearing its name, because at less than $1 \%$ it is readily recognized because of the great abundance of silicoflagellates and its large size. A rare occurrence of the species was noted in the upper Dictyocha grandis Zone; however, its earliest occurrence in Hole 703A is within Subchron C16R to uppermost Subchron C17N (39.24-39.80 Ma). The first occurrence of the species may be slightly older, as silica diagenesis has eliminated the older silicoflagellate record at this site. The last occurrence of $N$. pandalata is within Subchron $\mathrm{C} 16 \mathrm{~N}$, with samples bracketing the datum having an age of 38.65 to $38.3 \mathrm{Ma}$.

$N$. pandalata has a single isolated occurrence in Subchron C18R (43.0 Ma), however, its first consistent occurrence is younger than the initial calcareous nannofossil Chiasmolithus oamaruensis (39.8 Ma). The last occurrence of the species in Hole 702B was not noted in the present study. Subsequent examination of the upper portion of the section by Ciesielski (P. F. Ciesielski, unpubl. data) revealed common $N$. pandalata and a last occurrence in Sample 114-702B-4X-4, 60-62 $\mathrm{cm}$, with an estimated age of 38.65 to $38.3 \mathrm{Ma}$.

Holotype. PMO 121,055 (Pl. 9, Figs. 12, 13).

Isotypes. PMO 121,056 (PI. 9, Figs. 11), PMO 121,057 (PI. 9, Fig.14), PMO 121,058 (PI. 9, Fig. 15), and PMO 121,059 (Pl. 9, Fig. 16).

Type locality. Hole 703A, Meteor Rise, southeast Atlantic sector of the Southern Ocean.

Naviculopsis ponticula ponticula (Ehrenberg, 1844) Bukry, 1982 (Pl. 10, Fig. 11)

Remarks. A single specimen was noted in Sample 114-703A-3H-2, $40-42 \mathrm{~cm}$, of the lower Miocene.

\section{Naviculopsis ponticula spinosa Bukry, 1982}

(Pl. 10, Fig. 12)

Remarks. This species was noted in the lower Miocene between Samples 114-703A-4H-3, 40-42 cm, and 114-703A-3H-2, 40-42 cm, and is particularly common in the latter sample.

\section{Naviculopsis primativa $\mathrm{n} . \mathrm{sp}$.}

(Pl. 9, Figs. 6-9)

Description. This oldest known Naviculopsis is characterized by an elliptical basal ring with a length-to-width ratio of $\sim 2: 1$. An elevated apical apparatus occupies a position above one-half, or slightly less, of the basal ring. Apical elements are composed of a highly arched bar extending above the basal ring and perpendicular to the spines and of an additional bar that extends from the basal ring adjacent to one spine to the middle of the other bar. A slight indentation occurs in the transverse bar where it joins the bar aligned with the long axis of the basal ring. The basal ring is commonly slightly arched in the apical direction where it joins the spines (PI. 9, Fig. 6). The elevated nature of the apical structure at one end of the basal ring and the absence of any apical structure at the other is clearly evident in side or oblique view (Pl. 9, Fig. 6). Spine lengths are close to the length of the basal ring, although the spine at the end unoccupied by an apical structure tends to be approximately the same length as the basal ring; the other spine tends to be longer than the basal ring.

Remarks. Naviculopsis primativa resembles Naviculopsis danica Perch Nielsen (1976b) described from the lower Eocene of Denmark. $N$. primativa differs from this species in geologic range, as well as in the apical and basal structure. N. primativa has a short range in the lowermost upper Paleocene whereas $N$. danica was described from the lower Eocene. $N$. primativa is the oldest known representative of the genus and occurs prior to the first Naviculopsis constricta, rather than after the first $N$. constricta, as is the case with $N$. danica. The holotype of $N$. danica has three apical rods, one aligned with the short axis of the basal ring and two others joining obliquely to the opposite side of the basal ring, an arrangement different from that of $N$. primativa as noted previously. In addition, the holotype of $N$. danica has a more rounded basal ring, as opposed to the more elongate ring of $N$. primativa (length-to-width ratio of 2:1).

Occurrence. $N$. primativa was noted only in Sample 114-700B$30 \mathrm{R}-2,118-120 \mathrm{~cm}(61.5 \mathrm{Ma})$, where it is extremely abundant $(62 \%)$ and present in nearly every field of view. The sample is only slightly older than the one found containing Naviculopsis cruciata, its apparent descendant. It occurs within Subchron C26R, in the lower planktonic foraminifer P4 Zone and between samples bracketing the calcareous nannofossil Fasiculithus tympaniformis and Heliolithus kleinpellii Zones (Crux, this volume). The first occurrence of this species and genus is in the earliest late Paleocene and closely approximates the late/early Paleocene boundary.

Holotype. PMO 121,060 (Pl. 9, Figs. 7, 8).

Isotypes. PMO 121,061 (Pl. 9, Fig. 6) and PMO 121,062 (Pl. 9, Fig. 9).

Type locality. Northeast Georgia Rise, southwestern South Atlantic sector of the Southern Ocean.

\section{Naviculopsis trispinosa eminula $\mathrm{n}$. subsp.}

$$
\text { (P1. 8, Figs. 2-6) }
$$

Description. This distinctive descendant of Naviculopsis trispinosa is characterized by a short apical spine projecting upward and at a right angle from the basal ring plane. The location of the apical spine is not centrally located on the apical bar as in N. trispinosa. Instead, it is located in close proximity to one margin of the apical bar, where it descends to the basal ring. The length of the apical spine is one-half or less than that of $N$. trispinosa. When viewed obliquely from the side with the apical spine, its marginal location is readily apparent with the spine rising almost directly from the arched portion of the apical bar. Other aspects of the morphology are similar to $N$. trispinosa.

Remarks. The shortness and location of the apical spine make differentiation from $N$. trispinosa easy, except in abapical view when spine length and position are difficult to discern. Oblique abapical orientations pose little problem for identification as specimens seldom settle with this orientation. Other sections with $N$. trispinosa are being 
reexamined to determine whether this species has previously been lumped with $N$. trispinosa.

Occurrence. Naviculopsis trispinosa eminula evolved from Naviculopsis trispinosa trispinosa during the early Oligocene. The first occurrence of the species is in Sample 114-703A-12H-7, 2-4 cm. This sample falls within the Chiasmolithus subdistichus Subzone of the Isthmolithus recurvus Zone (NP19-21) and foraminifer Zone P18-20. Its first occurrence is immediately above a hiatus that has removed a portion of Subchron C13R and possibly a portion of C13N (P. F. Ciesielski, unpubl. data). In Hole 699A its first occurrence is between Samples 114-699A-32X-5, $60 \mathrm{~cm}$, and 114-699A-32X-7, $17 \mathrm{~cm}$. The species initial appearance in Hole 699A is below the Subchron C13N/C13R boundary, within the Reticulofenestra oamaruensis Subzone of the Isthmolithus recurvus Zone, and has an estimated age of 36.3 Ma. The last occurrence of the species in Hole 699A is noted within Subchron C9N, between 29.1 and $28.7 \mathrm{Ma}$. In Hole 703A it first occurs in Subchron C9R. Its earlier disappearance in Hole 703A may be a consequence of dissolution present in upper Subchron C9R and Subchron $\mathrm{C} 9 \mathrm{~N}$ at this site. The high sedimentation rate and continuous nature of the Hole $699 \mathrm{~A}$ section and the possible influence of dissolution in Hole 703A favor placement of the upper boundary as defined in Hole 699A.

Holotype. PMO 121,063 (PI. 8, Fig. 2).

Isotypes. PMO 121,064 (Pl. 8, Fig. 3), PMO 121,065 (PI. 8, Fig. 4), and PMO 121,066 (PI. 8, Figs. 5-6).

Type locality. Hole 703A, Islas Orcadas Rise, southwest Atlantic sector of the Southern Ocean.

\section{Naviculopsis trispinosa trispinosa (Schulz, 1928) Glezer, 1966} (Pl. 8, Fig. 1)

Remarks. A single specimen was found in Sample 114-702B-9X-1, $118-120 \mathrm{~cm}$, but was otherwise absent from the poorly preserved sediments of the middle Eocene of Hole 702B. If in place, this represents the oldest known occurrence of the species, which is within the Chiasmolithus solitus Zone (NP16). Common to abundant occurrences were noted throughout much of upper Eocene to lower Oligocene of Hole 703A.

\section{Naviculopsis sp. 1}

Remarks. Along with the first occurrence of the genus Naviculopsis in Paleocene Sample 114-700B-30R-2, 118-120 cm (61.5 Ma), are four specimens of Naviculopsis that bear a resemblance to Naviculopsis constricta. These specimens are found only in this single sample and precede the first occurrence of $N$. constricta in Sample 114-700B-29R-3, $37-38 \mathrm{~cm}$. These specimens differ from $N$. constricta by a distinct lack of any significant arching to the apical bar but are otherwise similar. Naviculopsis sp. 1 may be the ancestor to $N$. constricta.

\section{Naviculopsis sp. 2 \\ (PI. 10, Figs. 13-16)}

Remarks. Sample 111-703A-3H-2, 40-42 cm, exhibits a group of Naviculopsis morphotypes with features common to the other lower Miocene Naviculopsis ponticula and Naviculopsis obtusarca. Herein referred to as Naviculopsis sp. 2, these specimens are similar to Naviculopsis ponticula spinosa morphotypes having biconvex sides and little or no concavity at the bar-ring juncture, but lack the tubular spines. Naviculopsis obtusarca var. acicula also is similar in the shape of the basal ring and low, narrow apical bar. Naviculopsis sp. 2 appears as another variant of lower Miocene Naviculopsis with a hyaline region at the ends of the basal ring. In $N$. ponticula spinosa the hyaline region site is at the ring terminus and is mounted by a cylindrical spine. $N$. obtusarca has no spines, but instead the ends of the basal ring protrude as the result of a hyaline field elongated with the major axis. Naviculopsis sp. 2 appears to differ in generally having a triangular hyaline field at the ring terminus, surrounded by a thin remnant of the basal ring, giving the appearance of a spine.

Fifty-five specimens of Naviculopsis sp. 2 were noted in the single sample from Hole 703A. Further study and photomicrography are needed for description of this probable new species.

\section{Naviculopsis sp. 3}

(Pl. 9, Fig. 20)

Remarks. Three specimens of this extremely small silicoflagellate were found in Sample 114-703A-15H-2, 40-42 cm, within lower
Subchron C13R of the upper Eocene (P16/17, Reticulofenestra oamaruensis Subzone of the Isthmolithus recurvus Zone). These specimens have a basal ring of only $16 \mu \mathrm{m}$ and a ring width of $10 \mu \mathrm{m}$. Spines are aligned with the major axis and are shorter than the basal body length $(\sim 6 \mu \mathrm{m})$. The apical bar has a diameter less than that of the body ring and may have one or more small pustules.

\section{Naviculopsis sp. 4 \\ (Pl. 10, Figs. 1, 2, 3?)}

Remarks. Naviculopsis sp. 4 was found in three samples of the lower middle to upper middle Eocene of Hole 702B. These occurrences are slightly earlier than the first occurrence of another large species, Naviculopsis pandalata, which appeared during the middle Eocene. In addition to its large size, Naviculopsis sp. 4 resembles $N$. pandalata in its flattened spines and may be an ancestral species. Naviculopsis sp. 4 has a narrow apical bar that is less than the diameter of the basal bar. It also has a slight constriction to the basal ring at the bar-ring juncture. Basal ring length to maximum ring width dimensions are generally $2: 1$.

\section{ACKNOWLEDGMENTS}

The National Science Foundation and the Joint Oceanographic Institutions, Inc., are thanked for their sponsorship of the shipboard participation of PFC on Leg 114 of the Ocean Drilling Program. Financial support for this purpose was provided through the Texas A\&M Research Foundation/ United States Science Program award P.O. 20038. The same institutions are also thanked for their post-cruise financial support through award P.O. 20115. Dr. Kevin McCartney is thanked for a critical review of the manuscript. Ms. Susan Case-Ciesielski provided editorial and drafting and computer assistance.

\section{REFERENCES}

Bachmann, A., 1962. Eine neu entdeckte Silicoflagellidenart: Cannopilus ernestinae Bachmann, nov. spec. Mikrokosmos, 51:255.

Barron, J. A., Bukry, D., and Poore, R. Z., 1984. Correlation of the middle Eocene Kellogg Shale of northern California. Micropaleontology, 30:138-170.

Berggren, W. A., Kent, D. V., Flynn, J. J., and Van Couvering, J. A., 1985. Cenozoic geochronology. Geol. Soc. Am. Bull., 96:14071418.

Bukry, D., 1973. Silicoflagellate and diatom stratigraphy, Leg 16, Deep Sea Drilling Project. In van Andel, T. H., Heath, G. R., et al., Init. Repts. DSDP, 16: Washington (U.S. Govt. Printing Office), 815-870.

1975a. Coccolith and silicoflagellate stratigraphy, northwestern Pacific Ocean, Deep Sea Drilling Project Leg 32. In Larson, R. L., Moberly, R., et al., Init. Repts. DSDP, 32: Washington (U.S. Govt. Printing Office), 677-701.

, 1975b. Silicoflagellate and coccolith stratigraphy, Deep Sea Drilling Project Leg 29. In Kennett, J. P., Houtz, R. E., et al., Init. Repts. DSDP, 29: Washington (U.S. Govt. Printing Office), 845872.

1976a. Cenozoic silicoflagellate and coccolith stratigraphy, South Atlantic Ocean, Deep Sea Drilling Project Leg 35. In Hollister, C. D., Craddock, C., et al., Init. Repts. DSDP, 35: Washington (U.S. Govt. Printing Office), 885-917.

1976b. Silicoflagellate and coccolith stratigraphy, Norwegian-Greenland Sea, Deep Sea Drilling Project Leg 38. In Talwani, M., Udintsev, G., et al., Init. Repts. DSDP, 38: Washington (U.S. Govt. Printing Office), 843-855.

1977. Coccolith and silicoflagellate stratigraphy, South Atlantic Ocean, Deep Sea Drilling Project Leg 39. In PerchNielsen, K., Supko, P. R., et al., Init. Repts. DSDP, 39: Washington (U.S. Govt. Printing Office), 825-839.

1978a. Cenozoic coccolith and silicoflagellate stratigraphy, offshore northwest Africa, Deep Sea Drilling Project Leg 41. In Lancelot, Y., Seibold, E., et al., Init. Repts. DSDP, 44: Washington (U.S. Govt. Printing Office), 775-805.

1978b. Cenozoic coccolith, silicoflagellate, and diatom stratigraphy, Deep Sea Drilling Project Leg 44. In Bensen, W. E., 
Sheridan, R. E., et al., Init. Repts. DSDP, 44: Washington (U.S. Govt. Printing Office), 807-863.

1978c. Cenozoic silicoflagellate and coccolith stratigraphy, northwestern Atlantic Ocean, Deep Sea Drilling Project Leg 43. In Bensen, W. E., Sheridan, R. E., et al., Init. Repts. DSDP, 44: Washington (U.S. Govt. Printing Office), 775-805. 1978d. Cenozoic silicoflagellate and coccolith stratigraphy, southeastern Atlantic Ocean, Deep Sea Drilling Project Leg 40. In Bolli, H. M., Ryan, W.B.F., et al., Init. Repts. DSDP, 40: Washington (U.S. Govt. Printing Office), 635-639.

1979. Comments on opal phytoliths and stratigraphy of Neogene silicoflagellates and coccoliths at Deep Sea Drilling Project Site 397 off northwest Africa. In Luyendyk, B. P., Cann, J. R., et al., Init. Repts. DSDP, 49: Washington (U.S. Govt. Printing Office), 977-1009.

1981. Pacific Coast silicoflagellates, Deep Sea Drilling Project Leg 63. In Yeats, R. S., Haq, B. U., et al., Init. Repts. DSDP, 63: Washington (U.S. Govt. Printing Office), 539-557. 1982. Cenozoic silicoflagellates from offshore Guatemala, Deep Sea Drilling Project Site 495. In Aubouin, J., von Huene, R., et al., Init. Repts. DSDP, 67: Washington (U.S. Govt. Printing Office), 425-445.

1985. Cenozoic silicoflagellates from Rockall Plateau, Deep Sea Drilling Project Leg 81. In Roberts, D. G., Schnitker, D., et al., Init. Repts. DSDP, 81: Washington (U.S. Govt. Printing Office), 547-563.

1987. Eocene siliceous and calcareous phytoplankton, Deep Sea Drilling Project Leg 95. In Poag, C. W., Watts, A. B., et al., Init. Repts. DSDP, 95: Washington (U.S. Govt. Printing Office), 395-415.

Bukry, D., and Foster, J. H., 1973. Silicoflagellate and diatom stratigraphy, Leg 16, Deep Sea Drilling Project. In van Andel, T. H., Heath, G. R., et al., Init. Repts. DSDP, 16: Washington (U.S. Govt. Printing Office), 815-871.

Bukry, D., and Monechi, S., 1985. Late Cenozoic silicoflagellates from the northwest Pacific, Deep Sea Drilling Project Leg 86: paleotemperature trends and texture classification. In Heath, G. R., Burckle, L. H., et al., Init. Repts. DSDP, 86: Washington (U.S. Govt. Printing Office), 367-397.

Busen, K. E., and Wise, S. W., Jr., 1977. A silicoflagellate stratigraphy, Deep Sea Drilling Project, Leg 36. In Barker, P., Dalziel, I.W.D., et al., Init. Repts. DSDP, 36: Washington (U.S. Govt. Printing Office), 697-743.

Ciesielski, P. F., 1975. Biostratigraphy and paleoecology of Neogene and Oligocene silicoflagellates from cores recovered during Antarctic Leg 28, Deep Sea Drilling Project. In Hayes, D. E., Frakes, L. A., et al., Init. Repts. DSDP, 28: Washington (U.S. Govt. Printing Office), 625-691.

1983. The Neogene and Quaternary diatom stratigraphy of subantarctic sediments, Deep Sea Drilling Project Leg 71. In Ludwig, W. J., Krasheninnikov, V. A., et al., Init. Repts. DSDP, 71: Washington (U.S. Govt. Printing Office), 635-665.

Ciesielski, P. F., Hasson, P., and Turner, J. W., Jr., 1989. The stratigraphy of Neogene silicoflagellates from the Norwegian Sea, ODP Leg 104. In Eldholm, O., Thiede, J., et al., Proc. ODP, Sci. Results, 104: College Station, TX (Ocean Drilling Program), 497-526.

Ciesielski, P. F., Kristoffersen, Y., et al., 1988. Proc. ODP, Init. Repts., 114: College Station, TX (Ocean Drilling Program).

Deflandre, G., 1932. Sur la systématique des Silicoflagellés. Bull. Soc. Bot. Fr., 79:494-506.

1940. L'origine phylogénétique des Lyramula et l'évolution des Silicoflagellidées. C.R. Acad. Sci. Paris, 211:508-510.

1950. Contribution a l'étude des silicoflagellidés actuels et fossiles. Microscopie, 2:72-108, 117-142, 191-210.

Dumitrică, P., 1973. Paleocene, late Oligocene and post-Oligocene silicoflagellates in southwestern Pacific sediments cored on DSDP Leg 21. In Burns, R. E., Andrews, J. E., et al., Init. Repts. DSDP, 21: Washington (U.S. Govt. Printing Office), 837-883.

Ehrenberg, C. G., 1839. Uber die Bildung der Kreidefelsen und des Kreidemergels durch unsichtbare Organismen. K. Akad. Wiss. Berlin Abh. 1838 (1840, separate 1839), 59-148.
1844. Untersuchungen über die kleinsten Lebensformen im Quellenlande des Euphrats und Araxes, so wie über eine an neuen formen sehr reiche marine Tripelbildung von den Bermuda-Inseln vor. Ber. Verh. K. Preuss. Akad. Wiss. Berlin, 1844, 253-275.

1854. Mikrogeologie, das Erden und Felsen Schaffende Wirken des Unsichtbar Kleinen Selbständigen Lebens auf der Erde. Leipzig (Leopold Voss).

Frenguelli, J., 1940. Consideraciones sobre los silicoflagelados fosiles. Rev. Mus. La Plata, Secc. Geol., 2:37-112.

Glezer, Z. I., 1960. Paleogenovye kremnevye zhgutikovye vodorosli (Silicoflagellatae) Zapadnoy Sibiri. Inf. Sb. Vses. Nauchno-Issled. Geol Inst., 35:127-136.

1962. K voprosu o filogeneze kremnevykh zhgutikovykh vodoroslei (On the phylogeny of silicoflagellates). Paleontol. Z. $1: 146-156$.

1964. Novye Kremnevye Zhgutikovye Vodorsl: Paleogena SSSR. Akad. Nauk. SSSR, Novosti Sistematiki Rasteniy, Otdel. Ottisk, 57.

1966. Silicoflagellatophyceae. In Gollerbakh, M. M. (Ed.), Cryptogamic Plants of the U.S.S.R.: Akad. Nauk. SSSR, V. A. Komarova Bot. Inst. [Translated 1970, Jerusalem (Israel Program Sci. Translations), 7:1-363.]

Gombos, A. M., and Ciesielski, P. F., 1983. Late Eocene to early Miocene diatoms from the southwest Atlantic. In Ludwig, W. J., Krasheninnikov, V. A., et al., Init. Repts. DSDP, 71: Washington (U.S. Govt. Printing Office), 583-634.

Haeckel, E.H.P.A., 1887. Report on the radiolaria collected by H.M.S. Challenger during the years 1873-1876. Rep. Sci. Results of H.M.S. Challenger 1873-6, 18:1-1803.

Hajós, M., 1975. Late Cretaceous archaeomonadaceae, diatomaceae, and silicoflagellatae from the South Pacific Ocean, Deep Sea Drilling Project, Leg 29, Site 275. In Kennett, J. P., Houtz, R. E., et al., Init. Repts. DSDP, 29: Washington (U.S. Govt. Printing Office), 913-1009.

Hanna, G. D., 1928. Silicoflagellates from the Cretaceous of California. J. Paleontol., 1:259-264.

1931. Diatoms and silicoflagellates of the Kreyenhagen Shale. California Div. Mines State Mineral. Rept., 27:187-201.

Ichikawa, W., Fuji, N., and Bachmann, A., 1964. Fossil diatoms, pollen grains and spores, silicoflagellates and arachaeomonads [sic] in the Miocene Hojuji diatomaceous mudstone, Noto Peninsula, central Japan. Sci. Rep. Kanazawa Univ., 9:25-118.

Jerkovic, L., 1965. Sur quelques Silicoflagellidés de Yugoslavie: Paris (Lab. Micropaleont., Inst. Paleont. Museum), 1-8.

Lemmermann, E., 1901. Silicoflagellatae. Ber. Dtsch. Bot. Ges., 19:247-271.

Ling, H. Y., 1972. Upper Cretaceous and Cenozoic silicoflagellates and ebridians. Bull Am. Paleontol., 62:135-229.

1981. Crassicorbisema, a new silicoflagellate genus from the Southern Oceans and Paleocene silicoflagellate zonation. Trans. Proc. Paleontol. Soc. Japan, N. S., 121:1-13.

Locker, S., 1974. Revision der Silicoflagellaten aus der Mikrogeologischen Sammlung von C. G. Ehrenberg. Eclogae Geol. Helv., 67:631-646.

Mandra, Y. T., 1969. A New Genus of Silicoflagellata from an Eocene South Atlantic Deep-Sea Core (Protozoa: Mastigophora). Occas. Pap. Calif. Acad. Sci., 77.

Martini, E., and Müller, C., 1976. Eocene to Pleistocene silicoflagellates from the Norwegian-Greenland Sea (DSDP Leg 38). In Talwani, M., Udintsev, G., et al., Init. Repts. DSDP, 38: Washington (U.S. Govt. Printing Office), 857-895.

Okada, H., and Bukry, D., 1980. Supplementary modification and introduction of code numbers to the low-latitude coccolith biostratigraphic zonation (Bukry, 1973; 1975). Mar. Micropaleontol., $5: 321-325$.

Perch-Nielsen, K., 1976a. Late Cretaceous to Pleistocene silicoflagellates from the southern south west Pacific, DSDP Leg 29. In Kennett, J. P., Houtz, R. E., et al., Init. Repts. DSDP, 29: Washington (U.S. Govt. Printing Office), 677-721.

1976b. New silicoflagellates and a silicoflagellate zonation in North European diatomites. Bull. Geol. Soc. Den., 25:27-40. 


\section{P. F. CIESIELSKI}

Schulz, P., 1928. Beiträge zur Kenntnis fossiler und rezenter Silicoflagellaten. Bot. Arch., 21:225-92.

Shaw, C. A., and Ciesielski, P. F., 1983. Silicoflagellate biostratigraphy of middle Miocene to Holocene subantarctic sediments recovered by Deep Sea Drilling Project Leg 71. In Ludwig, W. J., Krasheninnikov, V. A., et al., Init. Repts. DSDP, 71: Washington (U.S. Govt. Printing Office), 687-737.

Stohr, E., 1880. Die Radiolarienfauna der Tripoli von Grotte, Provinz Girgenti in Sicilien. Paleontographica, 26:69-124.

Stradner, H., 1961. Uber fossile Silicoflagelliden und die Möglichkeit ihier Verwendung in der Erdölstratigraphie. Erdoel Kohle Erdgas Petrochem, 14:87-92.
Wise, S. W., Jr., 1983. Mesozoic and Cenozoic calcareous nannofossils recovered by Deep Sea Drilling Project Leg 71 in the Falkland Plateau region, Southwest Atlantic Ocean. In Ludwig, W. J., Krasheninnikov, V. A. et al., Init. Repts. DSDP, 71: Washington (U.S. Govt. Printing Office), 481-550.

Date of initial receipt: 11 July 1989

Date of acceptance: 4 January 1990

Ms 114B-145 


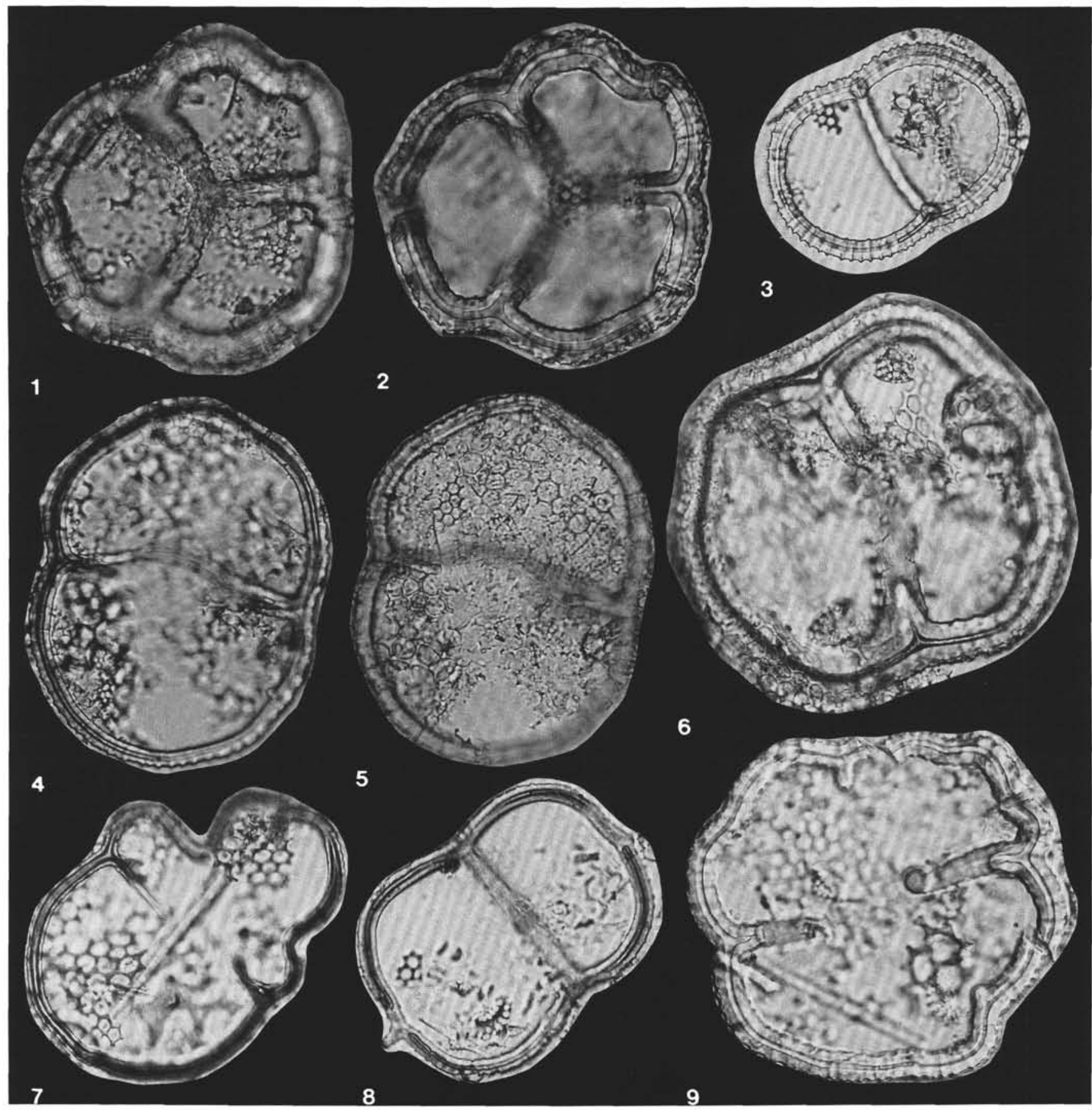

Plate 1. Paleocene silicoflagellates, all $500 \times$ except Fig. $8(600 \times)$. 1, 2. Corbisema disymmetrica crenulata n. comb., Sample 114-700B-32R-2, 35-37 cm. 1. apical focus, 2. basal focus. 3-6. Corbisema disymmetrica disymmetrica, Sample 114-700B-30R-1, 99-101 $\mathrm{cm} .4$, 5. Sample 114-700B-32R-1, 38-40 cm, 4. focus on basal ring, 5. focus on basal accessory spines. 6. Sample 114-700B-30R-2, 118-120 $\mathrm{cm}$. 7. Corbisema disymmetrica disymmetrica (aberrant form), Sample 114-700B-30R-2, 118-120 cm. 8. Corbisema constricta spinosa $\mathrm{n}$. subsp., isotype, Sample 114-700B-29R-1, 39-40 cm. 9. Corbisema disymmetrica disymmetrica (with incompletely formed apical bar), Sample 114-700B-30R-2, $118-120 \mathrm{~cm}$. 


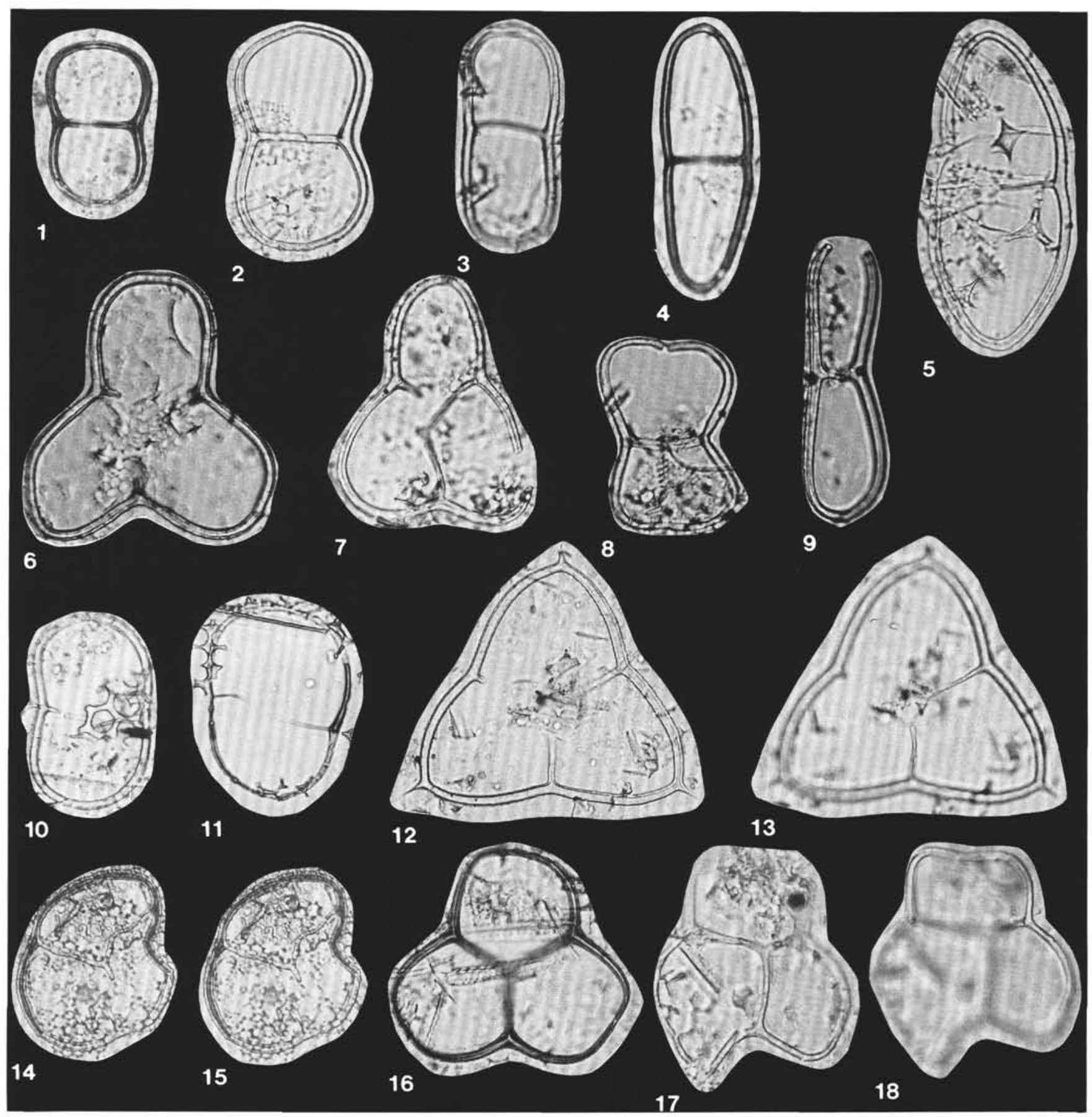

Plate 2. Paleocene and middle Eocene silicoflagellates, all $600 \times$ except figs. 11-13 and $15(500 \times)$. 1-2. Corbisema constricta constricta, 1. Sample 114-698A-12R-1, 40-42 cm, 2. Sample 114-700B-28R-4, 116-118 cm. 3, 4, 5? Corbisema naviculoidea, Sample 114-700B-700B-28R-2, $116-118 \mathrm{~cm}$. 6. Corbisema inermus var. 2, Sample 114-700B-31R-1, 29-31 cm. 7. Corbisema cf. inermus var. 2., Sample 114-700B-30R-4, 109-111 cm. 8. Corbisema constricta constricta, Sample 114-700B-28R-4, 116-118 cm. 9. Corbisema sp. cf. C. naviculoidea, Sample 114-700B-28R-4, 116-118 cm. 10, 11. Corbisema sp. 4, 10. Sample 114-702B-18X-2, 40-42 cm, 11. Sample 114-698A-3R-1, 40-42 cm. 12, 13. Corbisema apiculata (with thin apical bar), Sample 114-702B-16X-2, 140-142 cm. 12. basal focus, 13. focus on thin theadlike apical apparatus. 14, 15. Corbisema praedelicata n. sp., holotype, same specimen with different focus, Sample 114-700B-32R-5, 40-42 cm. 16. Corbisema cf. animoparallela, Sample 114-700B-27R-1, 60-62 cm. 17, 18. Corbisema animoparallela $\mathrm{n}$. sp., holotype, Sample 114-700B-30R-2, 118-120 cm. 17. apical focus, 18. basal focus. 

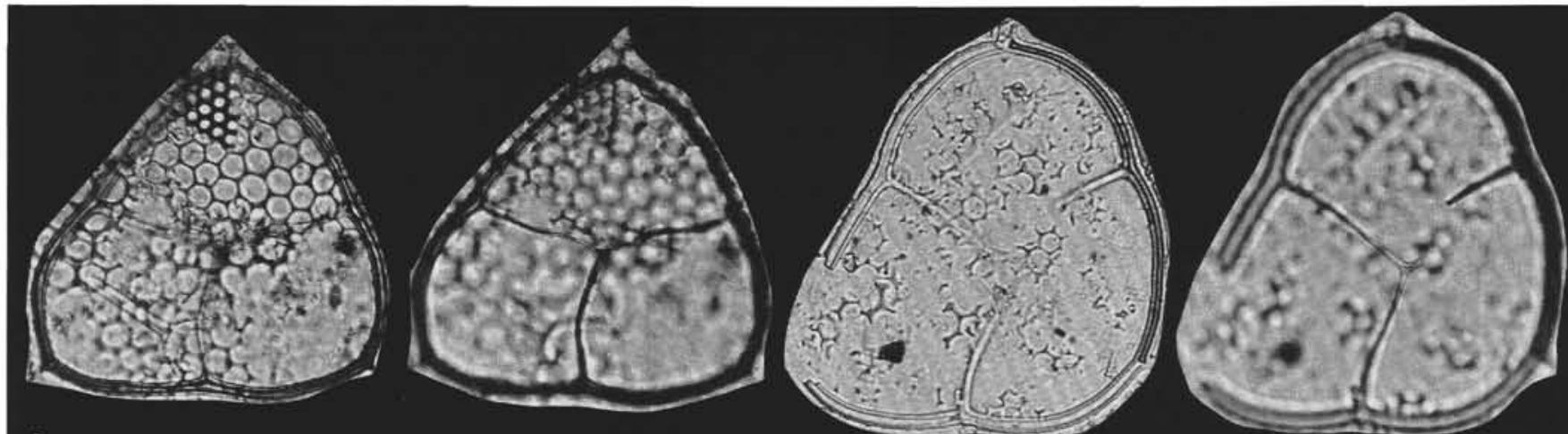

1

2

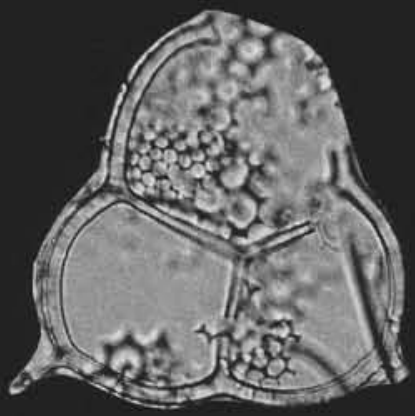

5

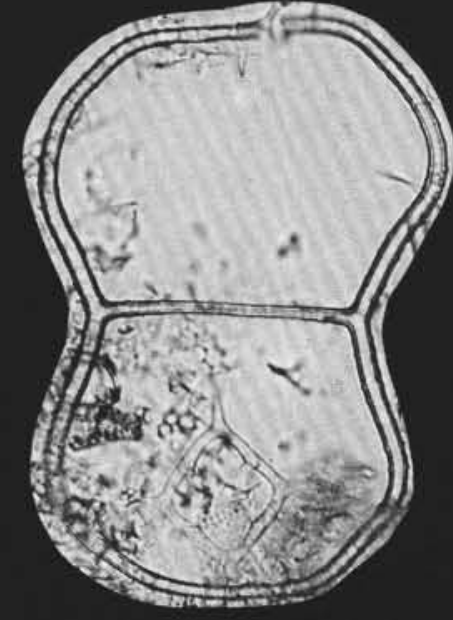

9

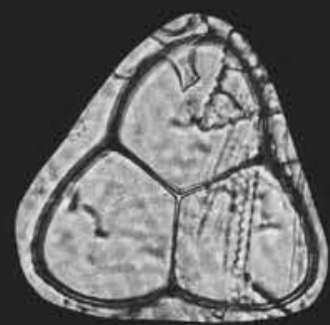

6

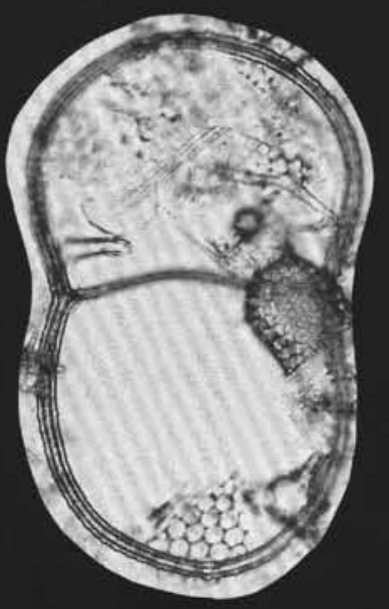

10
3

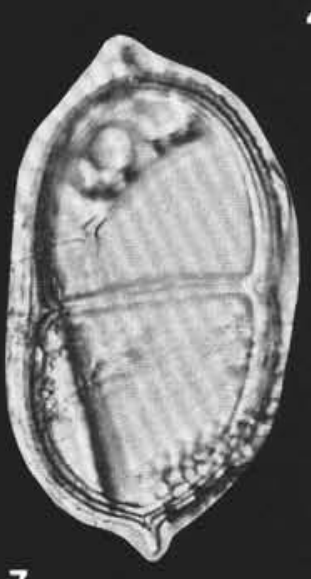

7

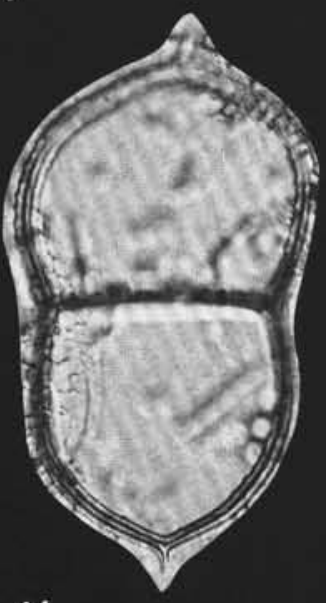

4

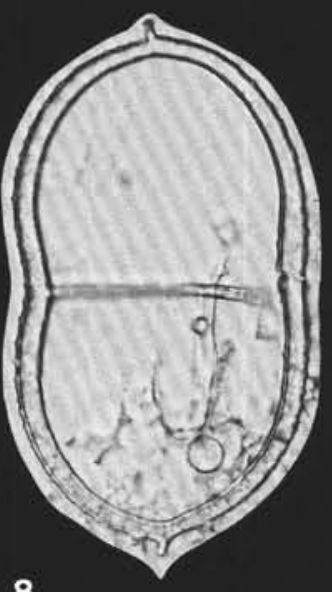

8

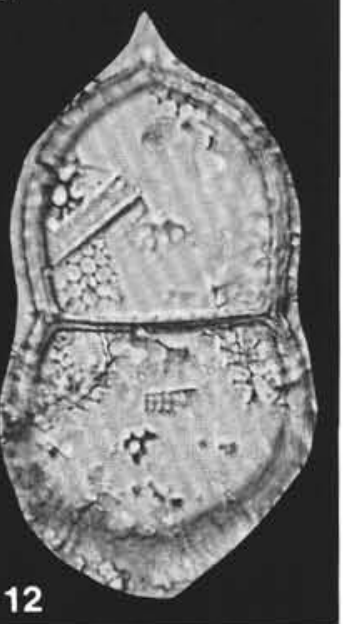

Plate 3. Paleocene silicoflagellates. 1-4. Corbisema delicata n. sp., Sample 114-700B-32R-5, 40-42 cm, 500×. 1, 2. holotype, basal and apical focus of the same specimen, 3, 4. isotype, basal and apical focus of the same specimen. 5. Corbisema cf. apiculata, Sample 114-700B-32R-3, $40-42 \mathrm{~cm}, 500 \times$. 6. Corbisema inermus inermus, Sample 114-700B-27R-1, 60-62 cm, 500×. 7, 8. Corbisema constricta spinosa, $600 \times .7$. isotype, Sample 114-700B-30R-2, 118-120 cm, 8. isotype, Sample 114-700B-29R-1, 39-40 cm. 9, 10. Corbisema constricta constricta, Sample 114-700B-28R-4, 116-118 cm, 500 $\times$. 11, 12. Corbisema constricta spinosa, holotype, high and low focus, Sample 114-700B-29R-1, 39-40 cm, $600 \times$. 


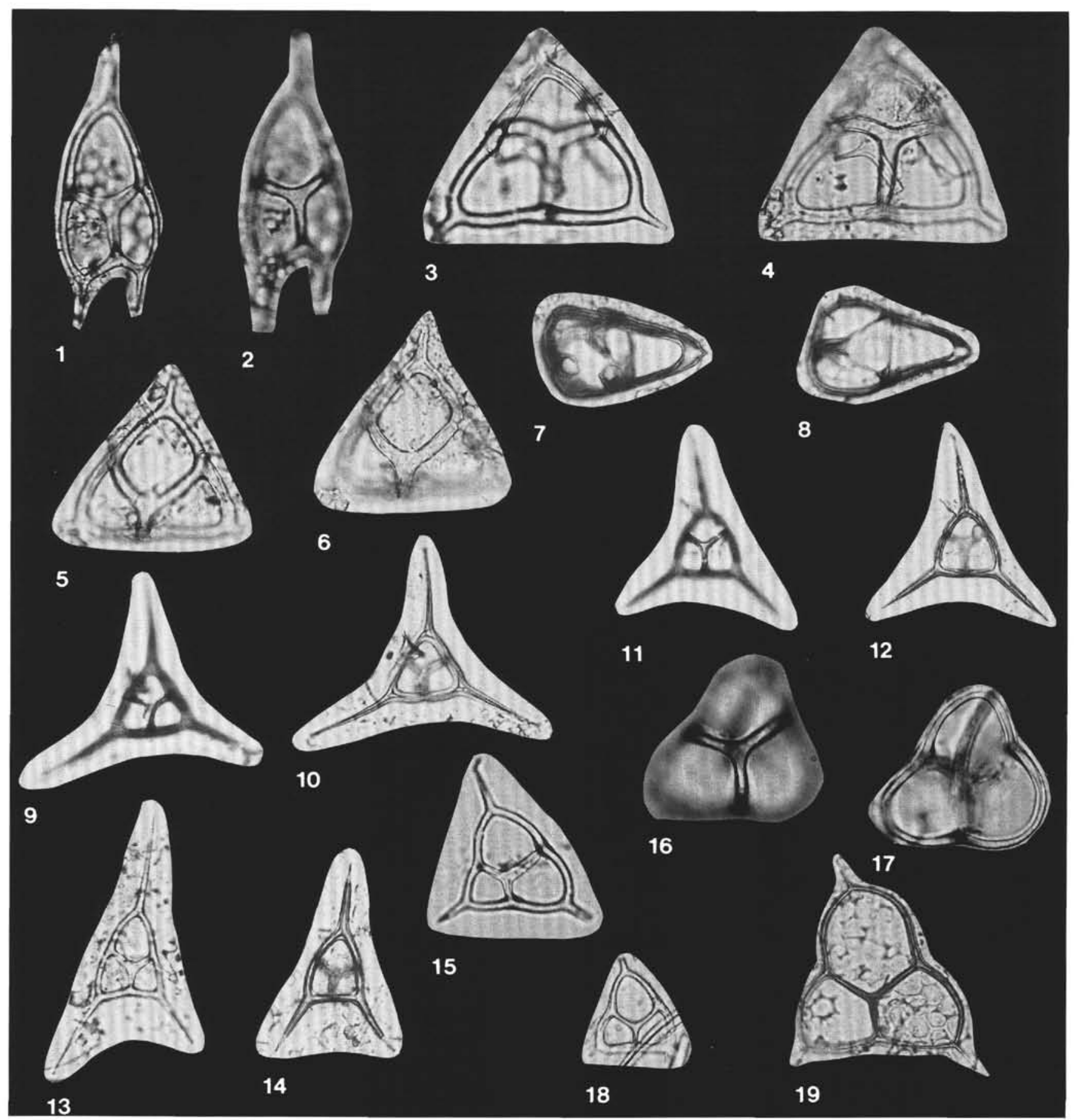

Plate 4. Paleocene silicoflagellates, all figures $600 \times$ except figs. 16 and 17 , which are $1250 \times .1$, 2. Corbisema hastata alta $\mathrm{n}$. subsp., Sample 114-700B-30R-2, 118-120 cm, holotype. 1. basal focus, 2. apical focus. 3-6. Corbisema camera n. sp., Sample 114-700B-30R-2, 118-120 cm. 3, 4. holotype, basal and apical focus of same specimen, 5, 6. isotype, basal and apical focus of same specimen. 7, 8. Corbisema falklandensis, 7. Sample 114-698A-12R-1, 40-42 cm, 8. Sample 114-700B-27R-1, 60-62 cm. 9-14. Corbisema triacantha lepidospinosa n. subsp., Sample 114-700B-30R-1, 99-101 cm. 9, 10. holotype, apical and basal focus of same specimen, 11, 12. isotype, apical and basal focus of same specimen, 13. isotype, apical focus, 14. isotype, basal focus. 15. Dictyocha aff. elongata, Sample 114-700B-30R-2, 118-120 cm. 16, 17. Corbisema inermus minor, Sample 114-700B-28R-4, 116-118 cm, apical and basal focus of same specimen. 18. Corbisema sp. 3, Sample 114-700B-27R-1, 60-62 cm. 19. Corbisema sp. 1, Sample 114-700B-32R-5, 40-42 cm. 


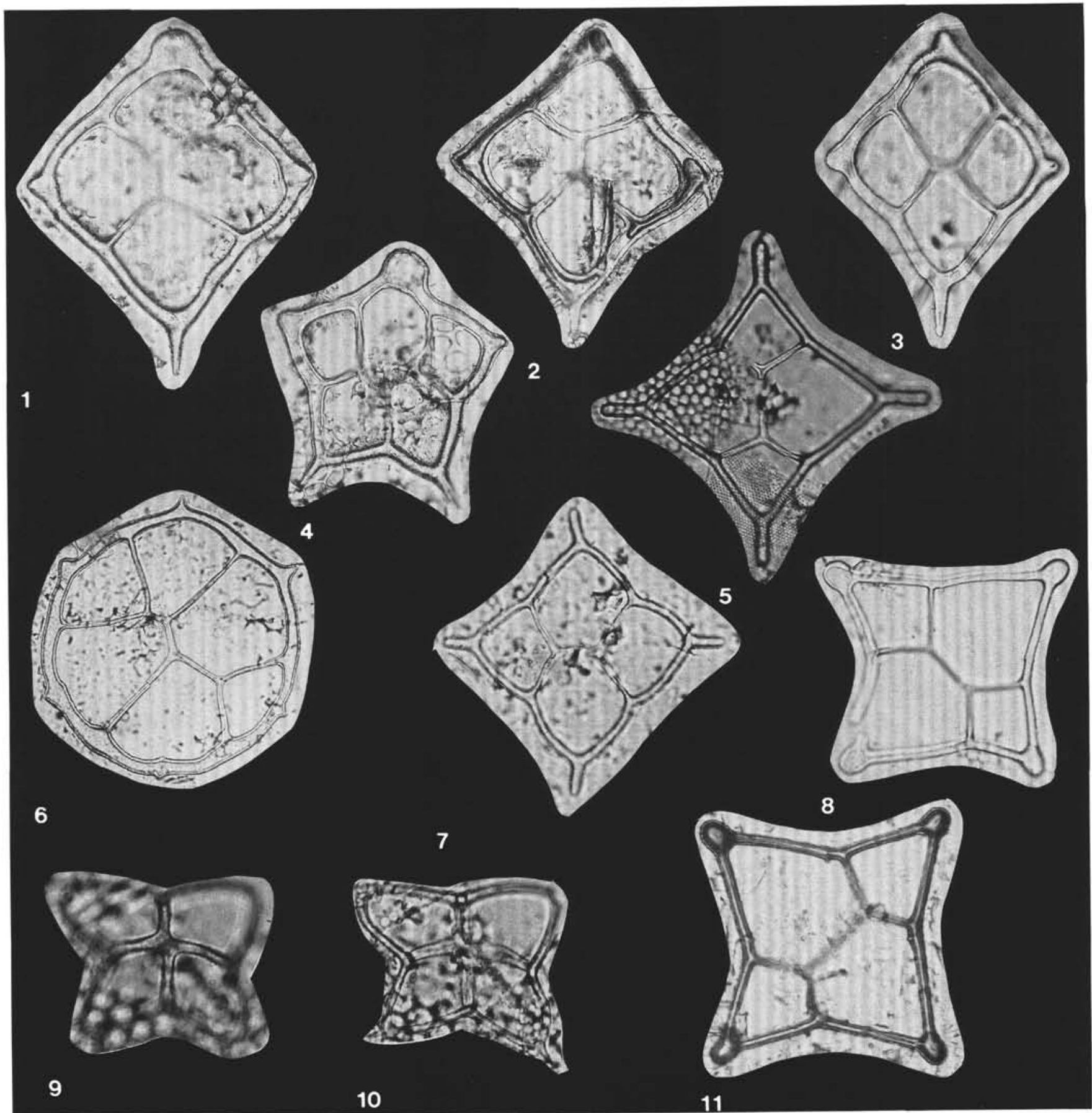

Plate 5. 1-3. Dictyocha stelliformis, Sample 114-702B-10X-1, 140-142 cm, 312×. 4. Dictyocha stelliformis (pentagonal basal ring), Sample 114-702B-10X-1, 140-142 cm, 312×. 5. Dictyocha quadria (with cylindrical spines), Sample 114-703A-17X-3, 103-105 cm, 500×. 6. Dictyocha grandis, Sample 114-702B-8X-3, 40-42 cm, 312×. 7. Dictyocha aff. quadria, Sample 114-702B-8X-3, 40-42 cm, 500×. 8, 11. Dictyocha quadria, 8. Sample 114-703A-18X-2, 94-96 cm, 600×, 11. Sample 114-703A-17X-3, 103-105 cm, 600×. 9, 10. Dictyocha cf. quadralta, Sample 114-700B-31R-6, 36-38 cm, $600 \times$. 9. apical focus, 10. basal focus. 


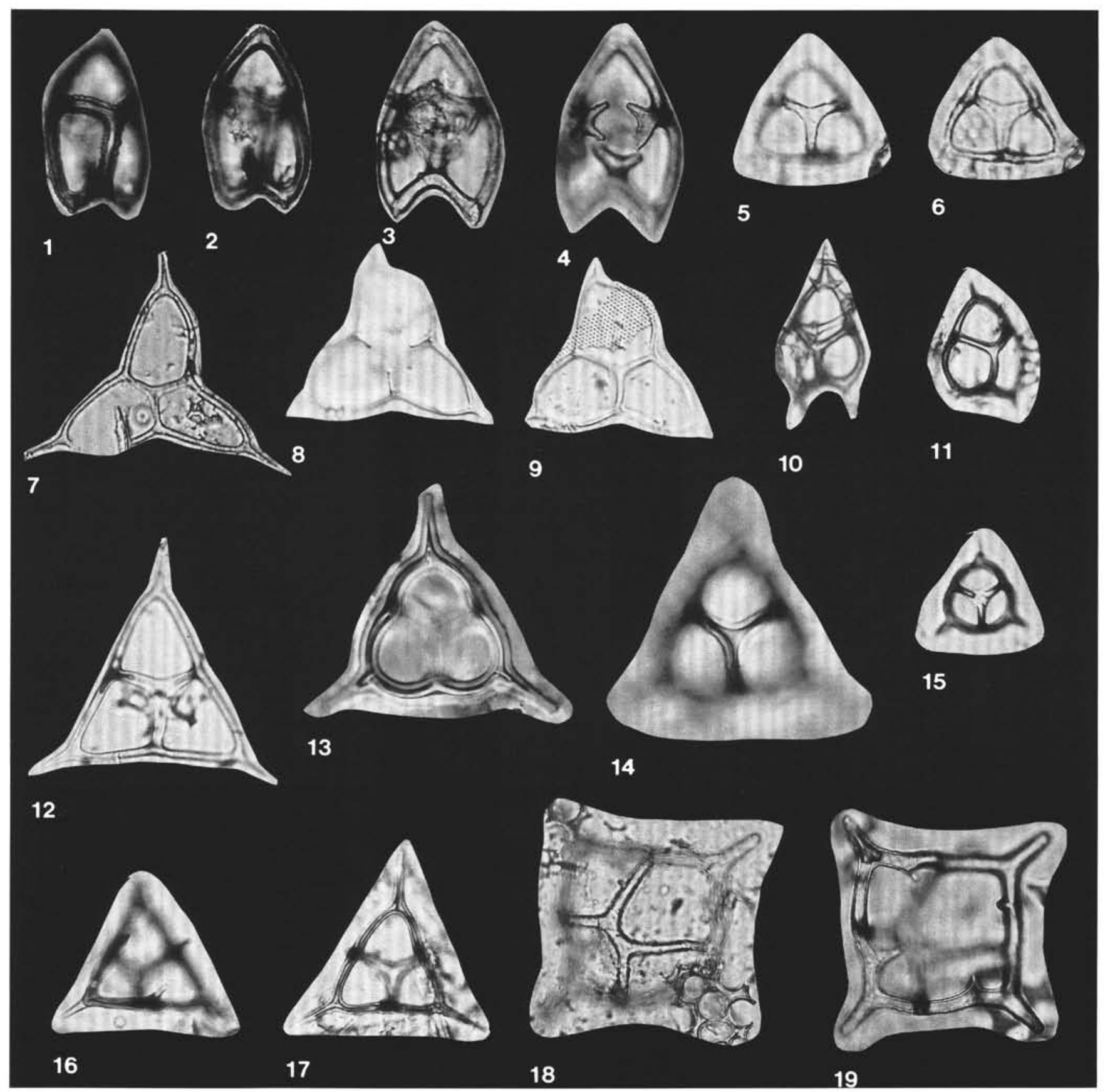

Plate 6. 1-4. Corbisema scapana $\mathrm{n}$. sp., Sample 114-700B-31R-6, 36-38 cm, 600×. 1, 2. isotype, apical and basal focus of same specimen, 3, 4. holotype, basal focus and focus on bifurcated basal accessory spines. 5, 6. Corbisema cf. regina, Sample 114-700B-31R-2, 9-11 cm, $600 \times$, apical and basal focus. 7. Corbisema cf. flexuosa, without apical plate, Sample 114-700B-31R-1, 29-31 cm, 600×. 8, 9. Corbisema katharinae, Sample 114-703A-16X-1, 44-46 cm, 600×. 8. focus on basal accessory spines, 9. basal focus. 10. Corbisema hastata var. 1, Sample 114-698A-3R-1, 40-42 cm, $600 \times$. 11. Corbisema incohata, Sample 114-703A-12H-3, 2-4 cm, 600 $\times$. 12. Corbisema angularis, Sample 114-703A-17X-3, 103-105 cm, 600×. 13, 14. Corbisema hastata globulata, Sample 114-700B-31R-2, 9-11 cm, 1250×, basal and apical focus of same specimen. 15. Corbisema amicula, Sample 114-703A-18X-3, 94-96 cm, 750×. 16, 17. Corbisema glezerae, Sample 114-700B-27R-1, 60-62 cm, 600 $\times$, focus on basal accessory spines and basal apparatus. 18, 19. Dictyocha sp. 3, Sample 114-702B-10X-5, $140-142 \mathrm{~cm}, 500 \times$, apical and basal focus. 


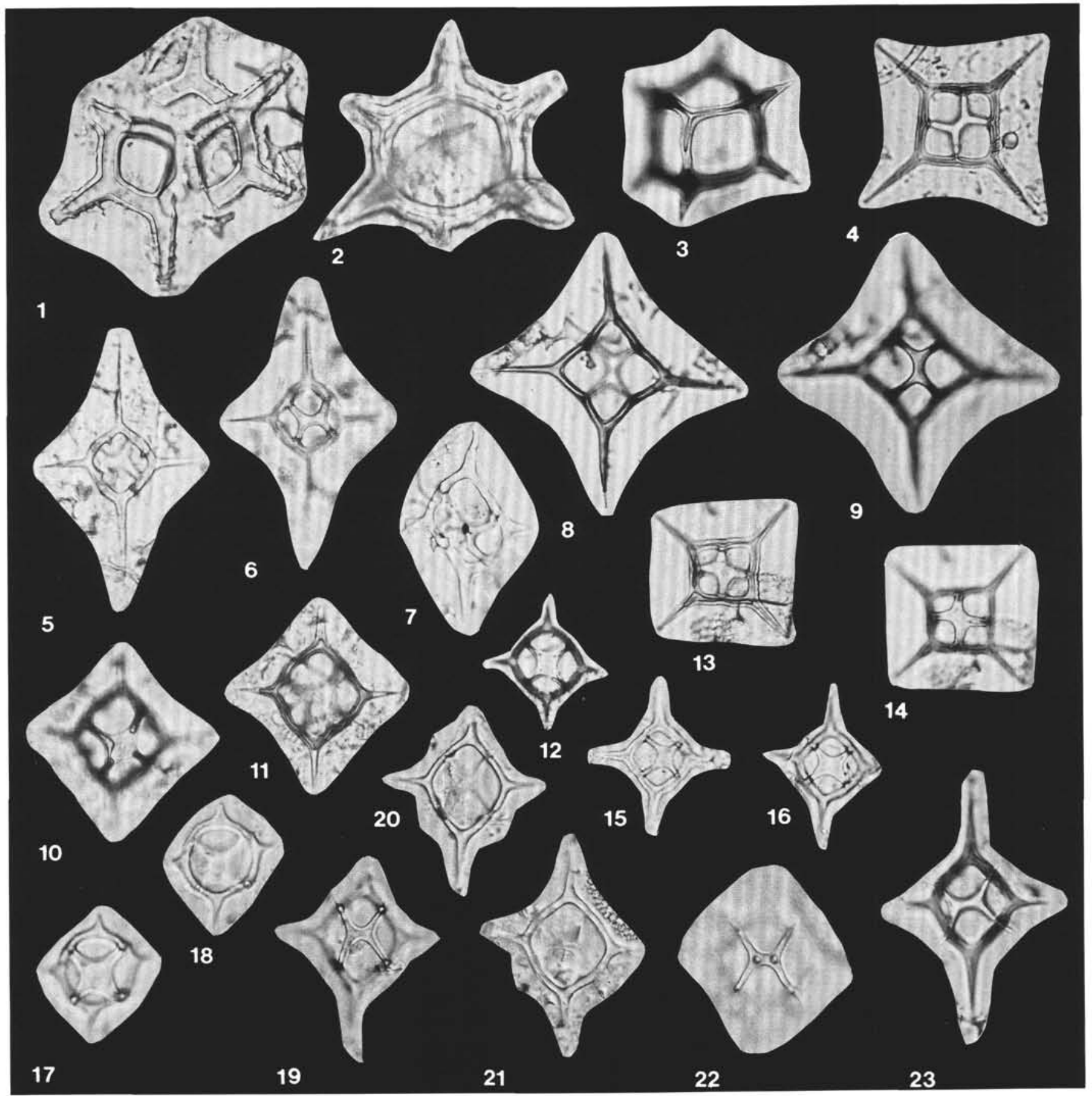

Plate 7. All figures $600 \times$ except figs. 17 and 18 , which are $750 \times .1,2$. Dictyocha hexacantha?, Sample 114-703A-18X-3, 94-96 cm. 3. Dictyocha hexacantha, Sample 114-703A-15H-4, 40-42 cm. 4. Dictyocha precarentis, Sample 114-700B-28R-2, 116-118 cm. 5, 6. Dictyocha cf. byronalis, Sample 114-702B-13X-1, 130-132 cm, abapical view of basal and apical apparatus. 7. Dictyocha torta, Sample 114-703A15H-6, 40-42 cm. 8, 9. Dictyocha precarentis, Sample 114-700B-28R-2, 116-118 cm, basal and apical view of same specimen. 10-12. Dictyocha deflandrei deflandrei, Sample 114-702B-12X-5, 119-121 cm. 10, 11. apical and basal focus of same specimen, 12. apical focus. 13, 14. Dictyocha deflandrei furtivia $\mathrm{n}$. subsp., holotype, Sample 114-700B-29R-3, 37-38 cm, basal and apical focus. 15, 16. Dictyocha deflandrei completa, Sample 114-703A-16X-1, 44-46 cm, basal and apical focus of same specimen. 17, 18. Dictyocha deflandrei sp. 1, reworked, Sample 114-703A-5H-4, 42-44 cm, apical and basal focus of same specimen. 19-23. Dictyocha aspera martinii, Sample 114-703A-17X-3, 103-105 cm. 19, 20. apical and basal focus of same specimen, 21, 22. basal and apical focus of same specimen. 


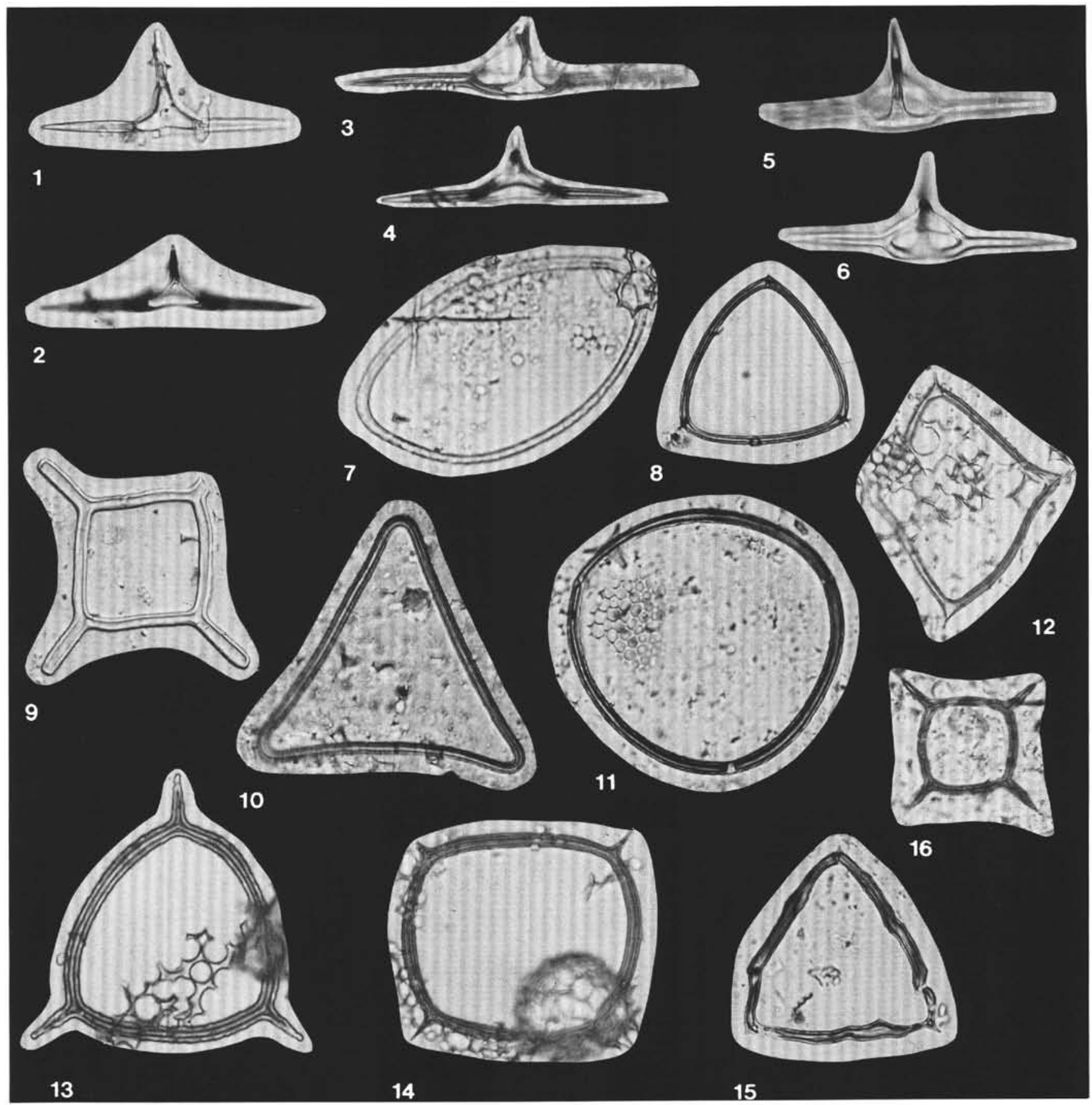

Plate 8. All figures $600 \times$. 1. Naviculopsis trispinosa trispinosa, Sample 114-703A-11H-6, 90-92 cm. 2-6. Naviculopsis trispinosa eminula n. subsp. 2. holotype, Sample 114-703A-11H-6, 90-92 cm, side view, 3. isotype, Sample 114-703A-12H-3, 2-4 cm, oblique apical view, 4. isotype, Sample 114-703A-11H-6, 90-92 cm, side view, 5, 6. isotype, Sample 114-703A-12H-3, 2-4 cm, oblique apical view with focus on apical spine and basal ring. 7. Bachmannocena connudata, Sample 114-698A-3R-1, 40-42 cm. 8. Bachmannocena pappii, Sample 11-703A-11H-6, 90-92 cm. 9. Bachmannocena paulschulzii, with cylindrical spines, Sample 114-703A-16X-1, 44-46 cm. 10. Bachmannocena oamaruensis, Sample 114-702B-10X-1, 140-142 cm. 11. Bachmannocena sp. 1, Sample 114-703A-13H-4, 60-62 cm. 12. Bachmannocena sp. schulzii?, Sample 114-702B-18X-4, 40-42 cm. 13. Bachmannocena apiculata inflata, Sample 114-698A-3R-1, 40-42 cm. 14. Bachmannocena paulschulzii var. 1, Sample 114-698A-3R-1, 40-42 cm. 15. Bachmannocena apiculata apiculata (aberrant form), Sample 114-703A-17X-3, 103-105 cm. 16. Bachmannocena vetula n. sp., holotype, Sample 114-702B-12X-5, 119-121 cm. 


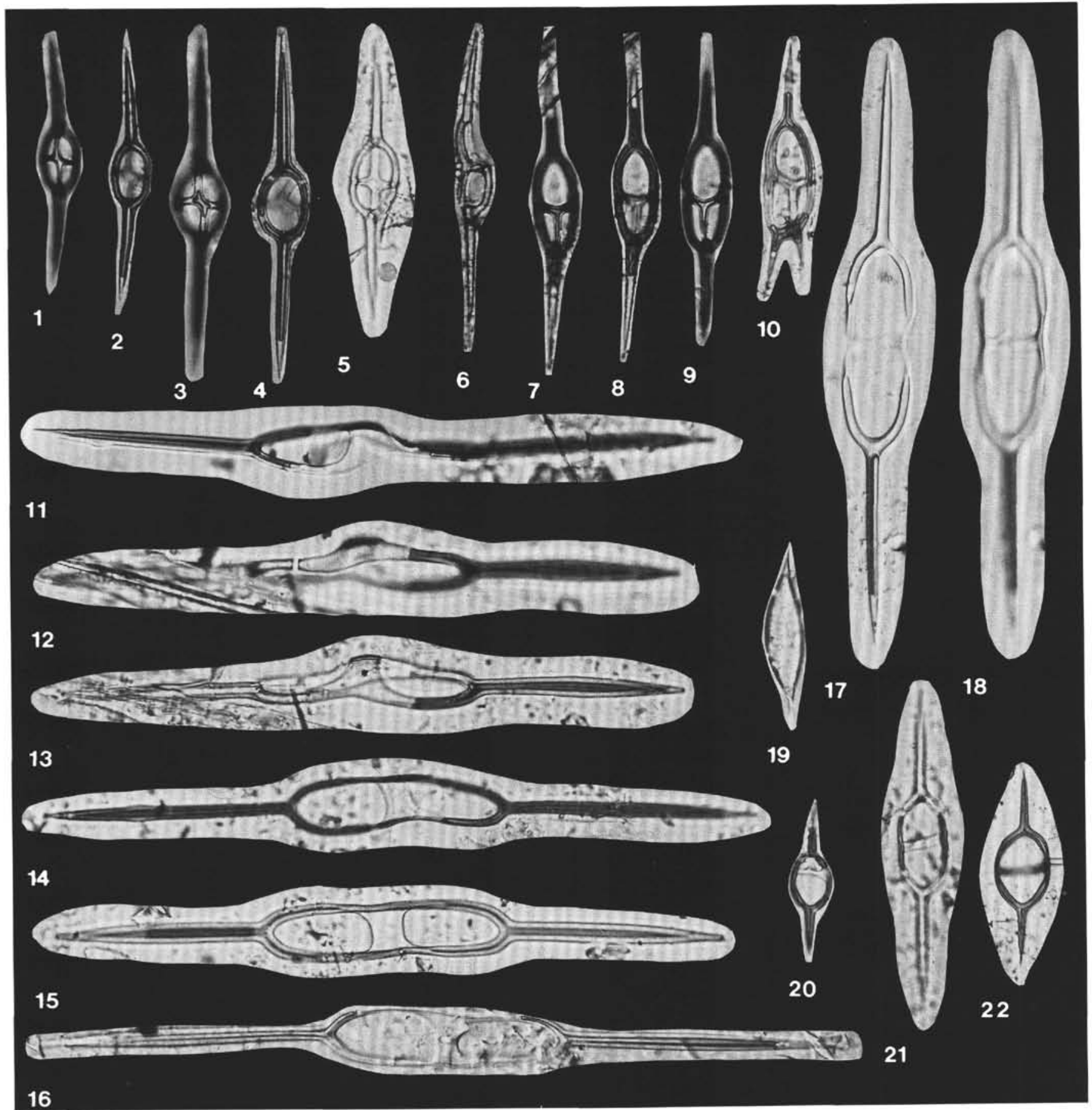

Plate 9. All figures $600 \times$. 1-4. Naviculopsis cruciata $\mathrm{n}$. sp., Sample 114-700B-30R-1, 99-101 cm, 1, 2. isotype, apical and basal focus of same specimen, 3, 4. holotype, apical and basal focus of same specimen. 5. Naviculopsis cf. cruciata, Sample 114-700B-30R-1, 99-101 cm, apical bars with less elevation above basal ring than previous specimens. 6-9. Naviculopsis primativa $\mathrm{n}$. sp., Sample 114-700B-30R-2, 118-120 cm. 6. isotype, side view revealing elevation of apical bars above one end of the basal ring, 7, 8. holotype, apical and basal focus of the same specimen, 9. isotype, apical focus. 10. Corbisema hastata alta $\mathrm{n}$. subsp., isotype, Sample 114-700B-30R-2, 118-120 cm. 11-16. Naviculopsis pandalata $\mathrm{n}$. sp., 11. isotype, Sample 114-700B-30R-1, 99-101 cm, side view with focus on near side, 12, 13. holotype, Sample 114-700B-30R-1, 99-101 cm, side view with focus on near and far sides, 14. isotype, Sample 114-700B-30R-1, 99-101 cm, oblique apical view, 15, 16. isotypes, Sample 114-700B-30R-1, 99-101 cm, apical views of different specimens. 17-18. Naviculopsis eobiapiculata, Sample 114-703A-15H-2, 40-42 cm. 19. Naviculopsis sp. aff. N. nordica hyalina, Sample 114-702B-9X-3, 118-120 cm. 20. Naviculopsis sp. 3, Sample 114-703A-15H-2, 40-42 cm. 21. Naviculopsis cf. constricta, Sample 114-702B-9X-1, 118-120 cm. 22. Naviculopsis biapiculata var. 1, Sample 114-703A-10H-5, 0-2 cm. 


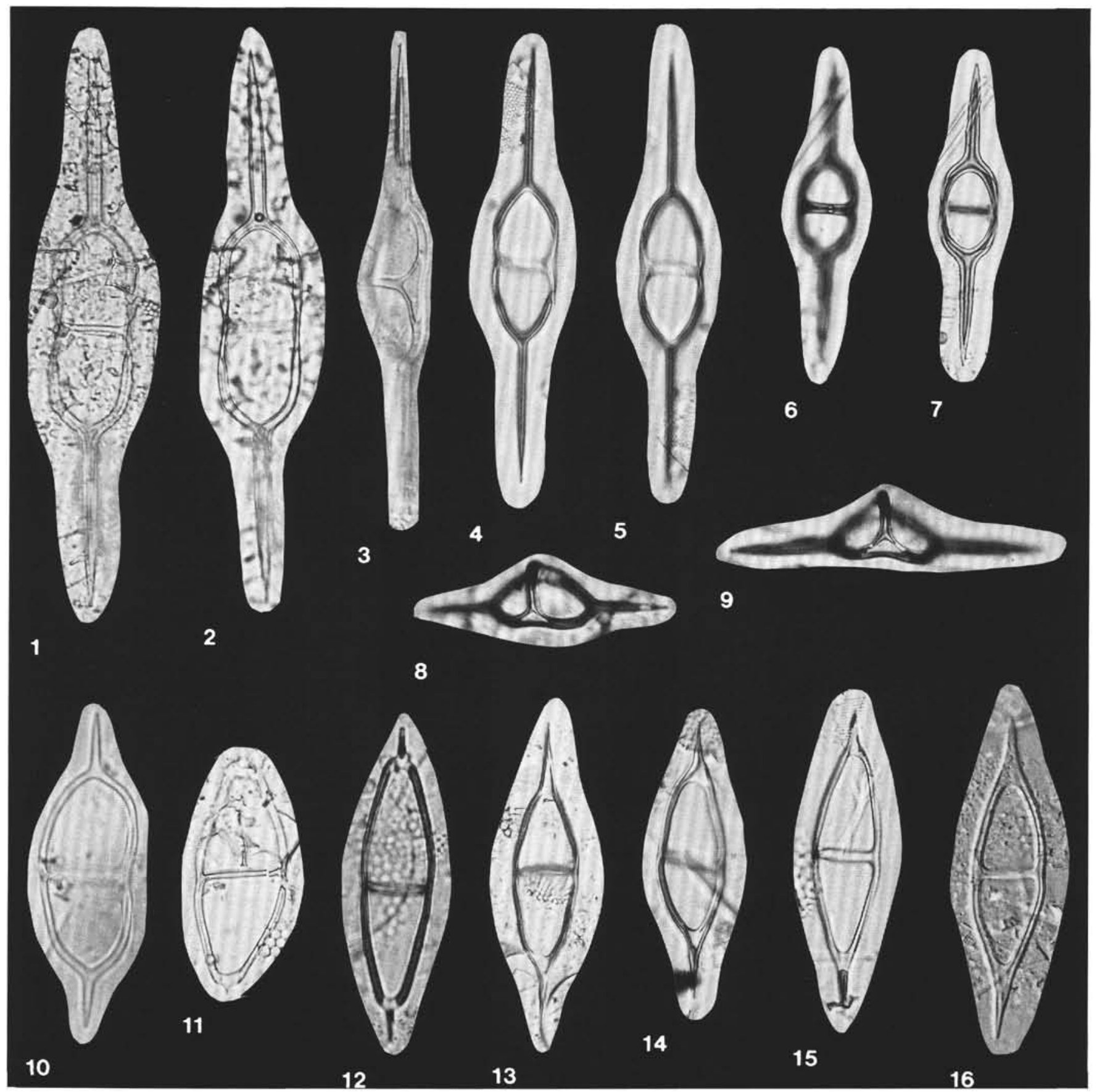

Plate 10. All figures $600 \times .1,2$. Naviculopsis sp. 4, Sample 114-702B-10X-5, 140-142 cm, apical and basal focus. 3. Naviculopsis cf. sp. 4, Sample 114-703A-17X-3, 103-105 cm, oblique apical view. 4, 5. Naviculopsis eobiapiculata, Sample 114-703A-10H-5, 0-2 cm. 6, 7. Naviculopsis biapiculata nodulifera $\mathrm{n}$. subsp., holotype, Sample 114-703A-11H-6, 90-92 cm, apical and basal focus. 8, 9. Naviculopsis biapiculata biapiculata, 8. Sample 114-703A-3H-2, 40-42 cm, 9. Sample 114-703A-7H-5, 110-112 cm. 10. Naviculopsis lata, Sample 114-703A-5H-4, 42-44 cm. 11. Naviculopsis ponticula ponticula, Sample 114-703A-3H-2, 40-42 cm. 12. Naviculopsis ponticula spinosa, Sample 114-703A-3H-2, 40-42 cm. 13-16. Naviculopsis sp. 2, Sample 114-703A-3H-2, 40-42 cm. 